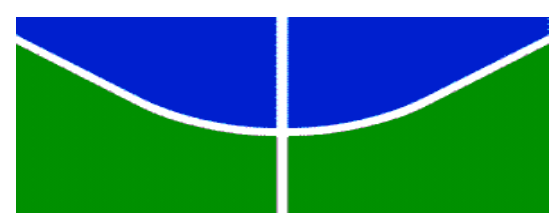

UNIVERSIDADE DE BRASÍLIA

INSTITUTO DE ARTES

DEPARTAMENTO DE ARTES CÊNICAS

PROGRAMA DE PÓS-GRADUAÇÃO EM ARTES - PROF-ARTES

SILVIA BEATRIZ PAES LIMA ROCHA GARCIA

TRANSIÇÕES DE IMPACTO:

UMA ANÁLISE DE CONSTRUÇÃO DE ESPETÁCULO TEATRAL

POR MEIO DO TEATRO-FÓRUM

Brasília

Julho/2016 
SILVIA BEATRIZ PAES LIMA ROCHA GARCIA

TRANSIÇÕES DE IMPACTO:

UMA ANÁLISE DE CONSTRUÇÃO DE ESPETÁCULO TEATRAL POR MEIO DO TEATRO-FÓRUM

Dissertação de Mestrado apresentada ao Programa de Pós-Graduação em Teatro do Departamento de Artes Cênicas da Universidade de Brasília, como requisito necessário à obtenção do título de Mestre em Teatro.

Orientadora: Clarice Costa da Silva

Brasília

Julho/2016 


\section{TRANSIÇÕES DE IMPACTO: UMA ANÁLISE DE CONSTRUÇÃO DE ESPETÁCULO TEATRAL POR MEIO DO TEATRO-FÓRUM}

Dissertação de Mestrado apresentada ao Programa de Pós-Graduação em Teatro do Departamento de Artes Cênicas da Universidade de Brasília, como requisito necessário à obtenção do título de Mestre em Teatro.

Orientadora: Clarice Costa da Silva

Banca Examinadora

Prof. ${ }^{\text {a }}$ Dra. Clarice Costa da Silva

Universidade de Brasília - UnB

Prof. a Dra. Luciana Hartmann

Universidade de Brasília - UnB

Prof. ${ }^{\circ}$ Dr. Rafael Litvin Villas Bôas

Universidade de Brasília - UnB

Brasília

Julho/2016 
Numa arte que tem o homem como sujeito, instrumento e objeto, Boal se perpetuará nos milhões de discípulos mundo afora. Mais que artista, foi um mestre. Assim como a grande obra de arte traz em si a discussão da sua própria gênese, a arte do mestre discute novas pedagogias de revelação do homem, da sociedade e do mundo. Fica a memória do artista e o caminho que escolheu, que revela aos cidadãos o opressor, e às pessoas a opressão introjetada.

Alcione Araújo 
Dedico essa pesquisa ao meu marido e minha filha pela cumplicidade desde sempre. 


\section{AGRADECIMENTO}

Agradeço primeiramente a Deus, por me dar o sopro da vida, de modo que neste universo eu possa fazer sentido.

Aos meus pais, Hermínio e Orquídea, pelo amor, sabedoria, dedicação e preparo para viver.

Aos meus irmãos, Marcos Augusto, Rafael Augusto e Daniel Augusto; minhas cunhadas, Andreia, Elisângela e Silvia Sthephanny; pela amizade, parceria e continuidade.

Ao meu marido, Bruno Garcia, pelo amor compromissado, pela trajetória, torcida, cumplicidade e fé.

À minha filha, Petra Victória, pelo amor incondicional, pela ternura e pelo sentido da luta.

A Augusto Boal (in memorian), por criar o Teatro do Oprimido, por me apresentar possibilidades de mudanças, um espaço onde eu possa questionar e encontrar respostas, pela generosidade em multiplicar sua genialidade.

Ao Centro de Teatro do Oprimido - CTO, por abrigar grupos que acreditam que o teatro é uma ferramenta de luta, um espaço de reivindicar direitos e liberdade de expressão.

À minha orientadora, Clarice Costa, por acreditar em mim, por me fazer crescer em meio ao caos e por ancorar minha pesquisa.

Aos meus amigos e, são tantos, pela confiança, parceria e estado de prontidão. 


\section{RESUMO}

Essa pesquisa analisa de que modo o Teatro do Oprimido pode ser utilizado como procedimento estético em prol da formação do indivíduo e de ações protagônicas. A proposta pedagógica baseia-se no arsenal do Teatro do Oprimido, com enfoque no Teatro-Fórum, uma das técnicas mais praticadas por esse sistema criado por Augusto Boal. O estudo fundamenta-se na criação do espetáculo Transições de Impacto, no qual apresenta situações de opressão debatidas com a intervenção direta da plateia. O debate encenado propõe ferramentas para que o sujeito se perceba e entenda suas potencialidades, utilizando-as com o intuito de se posicionar criticamente em relação às questões sociais presentes em seu cotidiano, através de um trabalho que perpassa pela linguagem artística, ao teatralizar conflitos sociais.

Palavras-Chave: Adolescentes; Improvisação; Protagonismo; Teatro-Fórum; Teatro do Oprimido. 


\begin{abstract}
This study analizes the use of the Oppressed Theatre as an aesthetic procedure in favor of the individual's formation and their leading actions. The pedagogical proposal is based on the arsenal of the Theatre of the Oppressed, focusing on the Forum Theatre, one of the most practiced techniques for this system created by Augusto Boal . The study is based on the creation of the performance Transitions of Impact, which presents oppression situations discussed with the direct intervention of the audience. The debate staged proposes tools for the subject to perceive and understand their potential, using them in order to position themselves critically in relation to social issues present in their daily lives through a work that runs through the artistic language when dramatizing social conflicts.
\end{abstract}

Keywords: Adolescents; Improvisation; Protagonism; Forum-Theatre; Theatre of the Oppressed. 
SUMÁRIO

$\begin{array}{ll}\text { APRESENTAÇÃOO } & 10\end{array}$

PARTE I - TRANSIÇÕES DE IMPACTO 13

1.1 - DESCRIÇÃO DA OFICINA OPRIERAM 23

1.2 - DESCRIÇÃO DOS JOGOS TEATRAIS 28

PARTE II - DA IMPROVISAÇÃO AO DIÁLOGO 67

2.1 - DRAMATURGIA DO TEATRO-FÓRUM 68

2.2 - INTERVENÇÕES NO ESPETÁCULO TRANSIÇÕES DE IMPCATO 80

CONSIDERAÇÕES FINAIS 95

$\begin{array}{ll}\text { REFERENCIAS } & 97\end{array}$

$\begin{array}{ll}\text { ANEXOS } & 101\end{array}$

$\begin{array}{ll}\text { APÊNDICE } & 128\end{array}$ 


\section{APRESENTAÇÃO}

Esta pesquisa insere-se em uma proposta pedagógica que reflete sobre a aplicabilidade do Teatro do Oprimido no desenvolvimento de ações protagônicas na formação do indivíduo. Ancora-se na Resolução n ${ }^{\circ}$ 04/2015 - PROF-ARTES e contempla minha experiência artística e de Multiplicadora do Teatro do Oprimido.

A pesquisa está dividida em duas partes. Na primeira, trago a descrição detalhada da Oficina de Teatro do Oprimido ministrada para adolescentes de duas escolas públicas do Distrito Federal, o que resultou no espetáculo Transições de Impacto. $\mathrm{Na}$ segunda parte, analiso as intervenções da plateia na apresentação do Teatro-Fórum, o depoimento dos adolescentes durante o processo e faço um recorte do arsenal do Teatro do Oprimido no que se refere à relação estabelecida entre espetáculo e espectador e, principalmente, na análise de situações de opressão.

Com o intuito de aprofundar sobre o processo metodológico desenvolvido na oficina e na investigação dos resultados a partir das intervenções vindas do TeatroFórum, dialogo com alguns autores além de Augusto Boal (1980; 1988; 1996; 2000; 2002; 2003; 2005; 2006; 2009). São eles: Alcione Araújo (2011), Anatol Rosenfeld (1982), Antônia Pereira Bezerra (1999), Bertolt Brecht (2005), Carmen Lúcia Abadie Biasoli (1999), Cilene Canda (2013), Desirree dos Reis Santos (2014), Flávio Desgranges (2003), Flávio Sanctum (2011), Hans Robert Jauss (2002), Jacob Guinsburg (2009), Jacob Levy Moreno (1984), José Carlos Libâneo (2004), Luigi Pareyson (1997), Luis Cláudio Cajaíba (2010), Marcos Bulhões Martins (2004), Maria Lúcia Pupo (1997; 2005), Martha Ribeiro (2008), Monique Borie (2004), Paulo Freire (1996; 2010), Sábato Magaldi (1984; 2001) e Tiche Vianna e Márcia Strazzacappa (2001).

Neste trabalho, em específico, foram associadas à montagem textual leituras e análises de duas peças de Boal - Murro em Ponta de Faca (1978) e Revolução na América do Sul (1960) -, com respectivos estudos dos contextos históricos; comparação dos conflitos existentes nas obras com questões sociais brasileiras e, por último, criação de cenas a partir das problemáticas levantadas.

Ao inserir na oficina a leitura desses dois textos dramáticos, objetiva-se evidenciar a importância do sujeito como protagonista de sua história, e não como títere 
de um sistema político em vigência, tornando-se vítima de jogos de poder. A primeira peça mantém-se atual ao evidenciar pessoas que vivem exiladas no sentido mais amplo, por viverem sem identidade, sem rumo, sem pátria. Ao retratar o desemprego, o segundo texto dramático serve de cenário para se discutir temas como: ineficiência política, corrupção e caos social por meio do protótipo do brasileiro.

O modo como a encenação é elaborada em Transições de Impacto favorece a reflexão sobre a mesma por parte do espectador, por estabelecer uma relação mais distanciada e mais convidativa à tomadas de decisão. Porém, ao mesmo tempo em que se propõe uma encenação com características que favoreçam um olhar sobre si mesma, são propostas relações empáticas, ou seja, de identificação com personagens protagonistas, as quais irão proporcionar a vivência do debate-fórum pelo viés teatral. Também se evidenciam na encenação cenas nas quais situações de opressão são teatralizadas, e divididas pela narração e comentários do personagem Coringa.

Boal utiliza esse termo de duas formas diferentes, em épocas distintas: Coringa - referente às diversas funções que exercia nos espetáculos apresentados no Teatro de Arena, e Curinga - o especialista do Teatro do Oprimido, que é comparado ao Curinga da carta de baralho, que assume papéis diferenciados de acordo com a necessidade do jogo.

O Teatro-Fórum é baseado em fatos do cotidiano, no qual personagens oprimidos e opressores entram em conflito nas defesas de seus desejos e interesses. Nesse confronto, o oprimido fracassa e o público é convidado, pelo Curinga - este termo sendo utilizado como mediador do Teatro do Oprimido -, a entrar em cena para substituir o Protagonista (Oprimido) e buscar alternativas para o problema encenado. Sua aplicação em comunidades e no âmbito pedagógico possibilita a diversificação, a dinamização e o fortalecimento das estratégias de ações na busca de soluções para as dificuldades advindas das relações estabelecidas socialmente.

No Teatro-Fórum, as relações de poder presentes no jogo cênico são socializadas entre atores e plateia, com isso, não existe monólogos e, sim, diálogos sucessivos entre espetáculo e espectador. O teatro proposto por Boal procura eliminar aquele espectador passivo que contempla a obra em cena; permite, entretanto, ter espect-atores, ou seja, aqueles que estão na expectativa de entrar em cena e agir. 
O espectador se torna espect-ator quando percebe que a problemática colocada em cena é passível de mudança e, antes, o conflito o desafia, o convida para protagonizar a cena dando sua solução. E o estímulo visual (imagem) e sonoro são pilares muito fortes desse jogo que atrai os sentidos do espectador. Jogos de poder, as relações de poderes, as hierarquias, as micro físicas do poder; as relações são teias intermináveis de troca de poder.

O protagonismo, nesse caso, é o processo no qual o adolescente se vê como sujeito e objeto de uma ação que gera o desenvolvimento de suas habilidades e competências. Quando o adolescente se torna o ator principal diante de um problema real, fruto de conflitos sociais presentes em seu cotidiano, e intervém com atitudes que visam ao diálogo e a propostas de soluções, ele ocupa um lugar protagônico. Nesse contexto, o adolescente pode ser visto como solução e, não, como problema, uma vez que sua ação participativa, construtiva e solidária possibilita a diversificação, a dinamização e o fortalecimento das estratégias de ações na busca de soluções para as dificuldades advindas do convívio social por meio do Teatro-Fórum.

Ao colocar o adolescente, individualmente ou em grupo, propondo a resolução de um conflito social presente em seu cotidiano, lhe é oferecida oportunidade para que atue com iniciativa, liberdade e compromisso. Assim é possível potencializá-lo através do Teatro-Fórum oportunizando voz ao sujeito por meio da apreensão estética. E quando essa resolução ocorre por meio da linguagem teatral, ela se abre à ação protagônica com um viés educativo, político e artístico. 


\section{PARTE I - TRANSIÇÕES DE IMPACTO}

O propósito em oferecer uma oficina de Teatro do Oprimido a adolescentes do Ensino Médio de duas escolas públicas do Distrito Federal deu-se pelo intuito de analisar a aplicabilidade de exercícios teatrais direcionados para esse tipo de público, por oferecer possibilidades de serem trabalhadas ações protagônicas que irão refletir não apenas em seus cotidianos, mas na construção de um olhar mais crítico e, consequentemente, em posicionamentos mais conscientes de suas vidas futuras.

Os exercícios propostos são jogos e técnicas presentes no arsenal do Teatro do Oprimido, pois procuram oferecer, aos participantes, um espaço no qual eles possam refletir e se pronunciar em relação a situações que os incomodam no cotidiano. É um recinto no qual o que lhes causa opressão pode ser expresso e trabalhado a partir dos objetivos propostos em cada jogo teatral e da técnica Teatro-Fórum.

O Teatro do Oprimido é um conjunto de exercícios, jogos e técnicas que ambiciona ensaiar a revolução, termo muito utilizado por Augusto Boal (1931-2009) em suas conferências. Mas para entender por que ele utilizou o teatro como um espaço de diálogo e ação política, relato brevemente, sua trajetória como artista, como diretor do Teatro de Arena e como exilado político.

Ao considerar que um engenheiro químico se tornou diretor, dramaturgo, crítico teatral e ainda criou o teatro para os oprimidos, é possível entender a lógica de Boal em defender um teatro que apostou na alquimia política da transformação a partir da mistura de arte e ação social. Para isso, é importante citar sua trajetória dentro do cenário artístico, de modo a justificar a presença de algumas técnicas teatrais no Teatro do Oprimido.

Ao se especializar em Dramaturgia na Columbia University, Boal aprofundou seus estudos em teóricos que discutiam o teatro e seus meios de produção. Também pôde vivenciar a prática no Actor's Studio, que utilizava o método de Constantin Stanislavski ${ }^{1}$ para o cinema e teatro. Segundo Monique Borie, em seus estudos sobre a

\footnotetext{
1 Constantin Stanislavski (1863-1938), ator e encenador russo, foi o fundador do Teatro de Arte
} de Moscou (1898) e os seus princípios inscrevem-se na corrente realista/naturalista. 
Estética Teatral: Textos de Platão a Brecht (2004), analisa que Stanislavski contribuiu, no que tange à formação do ator, ao redefinir a noção de realismo interior, numa esfera lúdica que é a essência do teatro. A resposta a esta dicotomia “(...) apoia-se num conjunto de técnicas interiores e exteriores, constituídas de uma psicofísica do ator que se costuma chamar de Sistema de Stanislavski”. (BORIE, 2004, p.371).

Concordo com Borie que esse Sistema primava pela subjetividade do personagem com a objetividade da situação vivenciada em cena, seja nas telas ou nos palcos. E que esta característica influenciou Boal quando, no arsenal do Teatro do Oprimido, ele as utilizou para as técnicas de ensaio presentes no Teatro-Fórum.

A convite de José Renato e Sábato Magaldi, Augusto Boal dirige o Teatro de Arena em São Paulo por quinze anos. Seu espetáculo de estreia foi Ratos e Homens, de John Steinbeck, no qual recebeu o prêmio Revelação da Associação Paulista de Críticos de Artes. Depois passou a dividir a direção com José Renato, incluindo textos de sua autoria e de autores estreantes advindos do Seminário de Dramaturgia - por ele coordenado - como Eles não Usam Black-tie, de Gianfrancesco Guarnieri. Ao ser entrevistado por Alcione Araújo (2011) ${ }^{2}$, Boal relembra momentos ímpares vividos no Seminário de Dramaturgia no Teatro de Arena.

\begin{abstract}
No seminário também davam aula Décio de Almeida Prado, Sábato Magaldi, Ana Paula Rosenfeld. Pessoas como o Jorge Andrade, que não eram do seminário, traziam suas peças pra gente ler. Outros só vinham para os debates. Apareceu muita gente. Então decidimos montar apenas autores novos (ARAÚJO, 2011, p. 14).
\end{abstract}

Sábato Magaldi em seu livro Panorama do Teatro Brasileiro (2001) reforça a importância da dramaturgia desenvolvida nesta época por Guarnieri, como a possibilidade de se manter atuante, driblando a censura imposta pela ditadura, ao utilizar metáforas em suas peças. De parceria com Boal, Guarnieri elaborou, sucessivamente, em 1965 e 1967, Arena Conta Zumbi e Arena Conta Tiradentes. Os heróis históricos dos títulos serviam apenas para acobertar o exame da situação atual, exortando o

\footnotetext{
2 Alcione Araújo (1945-2012) era formado em Engenharia e professor na Universidade Federal de Minas Gerais (UFMG). Era dramaturgo e cronista do jornal Estado de Minas. Esta entrevista ocorreu em fevereiro de 2000, na casa de Boal, quando a revista Palavra propôs que Alcione Araújo o entrevistasse por ocasião do lançamento de sua biografia Hamlet e o Filho do Padeiro. Em 2011, esta entrevista foi editada na Revista de Teatro da Sociedade Brasileira de Autores - SBAT.
} 
público à resistência contra o regime iníquo imposto à população. Como analisa Magaldi:

Com esses dois espetáculos, Boal inseriu no Teatro de Arena seus estudos sobre teatro praticados por Bertolt Brecht em suas peças. Com o intuito de criar um espaço de discussão sobre temas atuais, buscou-se na narrativa épica de Brecht, consolidar esse tipo de iniciativa (2001, p. 304).

Bertolt Brecht em Estudos sobre Teatro (2005, p.16) elabora uma tabela no qual distingue a forma dramática e a forma épica a respeito da teoria dramática. Essa tabela procura diferenciar a resposta emocional ao drama, da resposta racional ao épico. Ou seja, no emocional, abre-se a possibilidade de o espectador envolver-se no drama, de modo a aceitar como inalterável o desenrolar do mesmo; já no épico, distancia o espectador em como o drama é apresentado, mostrando sua ação como passível de alteração.

\begin{tabular}{|l|l|}
\hline \multicolumn{1}{|c|}{ Forma dramática de teatro } & \multicolumn{1}{c|}{ Forma épica de teatro } \\
\hline A cena "personifica" um acontecimento & Narra-o \\
\hline $\begin{array}{l}\text { Envolve o espectador na ação } \\
\text { e consome-lhe a atividade }\end{array}$ & $\begin{array}{l}\text { Faz dele testemunha, mas desperta-lhe a } \\
\text { atividade }\end{array}$ \\
\hline Proporciona-lhe sentimentos & Força-o a tomar decisões \\
\hline Leva-o a viver uma experiência & Proporciona-lhe visão do mundo \\
\hline $\begin{array}{l}\text { O espectador é transferido para dentro da } \\
\text { ação }\end{array}$ & É colocado diante da ação \\
\hline É trabalhado com sugestões & É trabalhado com argumentos \\
\hline Os sentimentos permanecem os mesmos & São impelidos para uma conscientização \\
\hline $\begin{array}{l}\text { Parte-se do princípio que o homem é } \\
\text { conhecido }\end{array}$ & O homem é objeto de análise \\
\hline O homem é imutável & $\begin{array}{l}\text { O homem é suscetível de ser modificado e } \\
\text { de modificar }\end{array}$ \\
\hline Tensão no desenlace da ação & Tensão no decurso da ação \\
\hline Uma cena em função da outra & Cada cena em função de si mesma \\
\hline Os acontecimentos decorrem linearmente & Decorrem em curva \\
\hline $\begin{array}{l}\text { Natura non facit saltus - Tudo na } \\
\text { natureza é gradativo }\end{array}$ & Facit saltus - Nem tudo é gradativo \\
\hline O mundo, como é & O mundo, como será \\
\hline O homem é obrigado & O homem deve \\
\hline Suas inclinações & Seus motivos \\
\hline O pensamento determina o ser & O ser social determina o pensamento \\
\hline
\end{tabular}


A teoria proposta por Brecht insere o teatro épico nos termos da política, ao propor a distinção entre o estético e o político. Este tipo de arte permite adquirir mudanças à estrutura da sociedade burguesa, tendo um caráter educativo ao expor contradições dessa mesma sociedade em caráter econômico, social e cultural. Esse tipo de arte trouxe a discussão em cena, ou seja, Brecht ao propor uma quebra na ação dramática com textos não lineares, com músicas que auxiliassem no discurso textual e com cenários que favoreciam a quebra da ilusão perante o espectador, constituía, assim, um novo passo: a função social sendo discutida através do teatro.

Em termos de análise do teatro no Ocidente, Brecht inaugurou a possibilidade de, em cena, utilizar o palco aberto; romper a ilusão ao eliminar a quarta parede; desmistificar a interpretação realista psicológica; trocar de cenários e figurinos a vista do espectador; propondo assim, que a plateia tivesse contato com os elementos que compusesse a encenação teatral em sua totalidade. Como o mesmo defende:

Há que combater esta forma de magia. É necessário renunciar a tudo o que represente uma tentativa de hipnose, que provoque êxtases condenáveis, que produza efeito de obnubilação (BRECHT, 2005, p. 17).

Ao analisar o cenário teatral brasileiro da década de 60, percebe-se que o Arena contribuiu para uma inovação inédita em relação a outros grupos da época. Parte dessa inovação consistia na formação de uma plateia mais crítica, trazendo, para este intuito, espetáculos que dialogassem com a realidade da época através de encenações pautadas nas teorias do Brecht. Boal procurava dar um caráter mais politizado nos espetáculos em que dirigia, ao aproximar as técnicas do Brecht com as do Stanislavski, e também ao referir-se à empatia do espectador em relação ao protagonista.

Essa empatia que o Boal se refere vai de encontro a uma parte da técnica brechtiana que ele refuta - a da quebra permanente da ilusão. Ao mesmo tempo em que Boal queria o espectador mais crítico, mais reflexivo, comentando sobre, também o queria próximo ao conflito do protagonista, isto é, que estabelecesse uma ligação com este personagem.

Para que houvesse em suas encenações a criticidade em relação ao todo e a empatia em relação ao protagonista, Boal inseriu outro personagem: o Coringa. O 
elemento Coringa era o intermediário entre o espetáculo e a plateia. Comentava sobre as situações colocadas em cena, como uma espécie de narrador e provocava os espectadores com o intuito de trazer reflexões imediatas ao que estava sendo encenado, visto que sua função tinha um cunho político.

Magaldi em seu livro Um Palco Brasileiro - O Arena de São Paulo (1984) analisa que Boal, ao colocar o Coringa em suas encenações, propõe o encontro de dois métodos característicos do teatro moderno: Stanislavski e Brecht. Ou seja, tem o intuito de fazer com que o espectador se identifique ao mesmo tempo que consiga comentar sobre o espetáculo em si. Como ele expõe: "A função 'Coringa', da total abstração, com significado crítico, se contrapõe à função protagônica da personagem que procura reconquistar a empatia com o público" (MAGALDI, 1984, p. 78).

Flávio Sanctum em sua dissertação Estética do Oprimido de Augusto Boal Uma Odisséia pelos Sentidos. (2011) completa:

De acordo com estudos sobre o Sistema Coringa, o desejo de Boal em formar uma plateia crítica através do caminho empático era autêntico, porém contraditório, se pensado em primeira instância. Pois, ao analisar as duas técnicas, verifica-se que há uma incompatibilidade entre o distanciamento proposto por Brecht, que refuta a quarta parede na ilusão teatral e revela ao espectador o espetacular em todas suas tecnicidades e parafernálias; no entanto, Stanislavski propõe uma pintura teatral, que é produzida no palco enquanto moldura e não tem nenhuma relação com a plateia (SANCTUM 2011, p. 20).

Mesmo com essa contradição - da empatia ao distanciamento -, Boal propõe o diálogo entre as técnicas desses dois autores, garantindo a criticidade da plateia, ao mesmo tempo em que o espetáculo pode ser visto como reflexo da vida real. É como salienta Martha Ribeiro em $O$ que faz de uma obra um clássico? (2008, p. 213) "A sedução do teatral perpassa pelo jogo enigmático de identificação e distanciamento que envolve o espectador no momento da ação, na famosa ideia de pacto teatral".

A montagem de Arena Conta Zumbi e Arena Conta Tiradentes trouxe para os palcos do Teatro de Arena: encenações inovadoras, utilização dos elementos do teatro épico e o sistema coringa. Para Anatol Rosenfeld em O Mito e o Herói no Moderno Teatro Brasileiro (1982, p. 13) "Supõe-se que tal tipo de representação desvinculada 
favoreça a apreciação crítica do público, visto ela impedir a intensa identificação emocional".

O referido autor completa:

Tal desempenho é "épico", isto é, narrativo. O narrador, que narra uma história qualquer aos seus ouvintes presentes, é, por assim dizer, um único "ator" que desempenha os papéis de todos os personagens da estória. (...) deve "transparecer" através da variedade dos comediantes que já não "encarnam" o papel, mas são portadores e "narradores" dele (ROSENFELD, 1982, p. 13).

A figura do Coringa nesse contexto auxilia o entendimento desses aparentes paradoxos nos espetáculos apresentados no Arena:

A circunstância de interpretarem os atores vários papéis, além de facilitar o efeito de estranhamento, permite concentrar o desempenho num núcleo pequeno e fixo, que se desdobra em numerosas personagens (MAGALDI, 1984, p.79).

Porém, Rosenfeld (1982) ao analisar o Sistema Coringa, não desmereceu e nem refutou a inovação proposta por Boal; contudo chamou a atenção quanto ao espaço limitado do Teatro de Arena, que, diante dessa proposta de encenação, exigia-se muito do público: o ato do distanciamento e o efeito da empatia.

Isso, já em si um tanto difícil no pequeno círculo da arena, torna-se quase impossível diante da eventual presença do Coringa dirigindo-se à plateia, derrubando, portanto, as paredes enquanto o ator protagônico e o público se esforçam ao mesmo tempo por construí-las imaginariamente (ROSENFELD, 1982, p. 21).

Outra característica do Sistema Coringa consistia em criar um rodízio entre os atores, ou seja, eles interpretavam diferentes personagens em cada apresentação. Com isso, os atores trabalhavam na perspectiva de interpretar todos os personagens, uma vez que, como num sorteio, seus papéis eram selecionados minutos antes do espetáculo. 
Boal acreditava que quando os atores eram provocados a experimentar novos desafios, interpretando diferentes papéis, criava-se, portanto, interpretações menos cristalizadas no que se referia à subjetividade dos personagens. Com isso, abria-se outro precedente: o de poder criticá-los. Como sinaliza Magaldi:

Um papel pode ser encarnado numa cena por um ator e, na seguinte, por outro e assim sucessivamente, de acordo com as necessidades da distribuição. Com essa liberdade, a personagem não se confina às características de um intérprete, incorporando os achados de todos (MAGALDI, 1984, p. 79).

Esse tipo de construção tinha um caráter épico, diferente do personagem protagonista, que possuía características do Sistema de Stanislavski em sua construção. No sistema Coringa, os atores revezavam-se em diferentes papéis numa forma de desvinculação entre ator e personagem. Para isso, utilizavam-se de máscaras - que traziam características sociais e/ou psicológicas -, como caracterização de personagens no qual a plateia pudesse identificá-los. Assim, “(...) os atores colocavam-se na mesma perspectiva dos narradores, interpretando, portanto, 'a totalidade da peça', já que atuariam e se veriam atuar" (MAGALDI, 1984: 78).

Jacob Guinsburg em seu livro Dicionário do Teatro Brasileiro - temas, formas e conceitos (2009), faz uma análise em relação as observações de Sábato Magaldi a respeito do caráter inovador proposto por Boal na época em que dirigiu o Teatro de Arena e, consequentemente, implementou o sistema Coringa. Segundo o autor:

(...) Sábato Magaldi observa que, ao preservar a possibilidade empática, o sistema arquitetado por Boal difere da teoria brechtiana. O Coringa (como os coringas dos jogos de carta) é polivalente, um comentarista explícito interpretando qualquer papel e assumindo qualquer função necessária ao desenvolvimento do espetáculo (GUINSBURG, 2009, p. 106).

$\mathrm{Na}$ verdade, analiso a tentativa de Boal em unir numa mesma encenação, tanto elementos defendidos por Stanislavski como por Brecht. Pois isso ia de encontro à sua intenção de criar dois momentos durante a apresentação dos espetáculos: o primeiro seria o distanciamento na plateia em relação a problemática encenada - que podia ser 
comparada com a situação econômica e social vigente no país -, o segundo seria a identificação com o protagonista pelo viés de seus anseios e objetivos - que poderiam ser comparados pelos anseios e objetivos da plateia.

Neste período, o rumo ideológico de esquerda do Teatro de Arena, de sua expansão cultural e política começou a declinar na perspectiva da dramaturgia e encenações, devido às intervenções no período da ditadura militar. Assim, encerra-se a trajetória do Boal neste espaço de experimentações, descobertas, tentativas de exercer a democracia por um viés estético e, porque não, ilusório na perspectiva de dar voz ao povo, de propiciar mudanças aos oprimidos.

Nessa época - 1971 -, Boal foi preso, torturado e exilado pela ocupação dos militares no poder que assolou o país. Em seu livro autobiográfico Hamlet e o Filho do Padeiro (2000), Boal desabafa; esse regime ditatorial, o tornou mais um oprimido na incansável tentativa de se fazer ouvir.

A cela me hospedou - fiquei só! - estava no ângulo reto: através de janelinhas - a minha e a do corredor - via o longo caminho; imaginava o curto, à direita. Tinha dois passos apressados de comprido, menos de dois tímidos de largura. Pia e latrina, rato no ralo. O silêncio, diferente dessa estreiteza, era amplo, imenso, infinito. Pela terceira vez, ouvi silêncio, gritado: ali se berrava sem som, cinema emudecido. Queria som de verdade, real ruído, e me assustavam barulhos silenciosos que escutava sem ouvir. Joguei o sapato no chão, vi e ouvi. Joguei sapato no teto, dei soco na parede, pontapé no catre, raiva silenciosa. Doeu. Através das paredes grossas imaginei gemidos torturados (BOAL, 2000, p. 274).

Nesta época de exílio, as técnicas que compõem o arsenal do Teatro do Oprimido começaram a ser experimentadas. Suas técnicas têm o objetivo de dar voz ao oprimido, ensaiando possíveis mudanças sociais por meio do contato com o fazer teatral. A passividade do espectador, enquanto plateia, modifica-se quando o contexto da encenação ganha vida, transformando-se em parte da obra de arte ao exercer o protagonismo em cena, assumindo o papel que Boal intitula espect-ator.

Esse termo é a junção de espectador + ator que resulta na proposta oferecida ao espectador de, ao mesmo tempo em que assiste ao espetáculo, no final, é convidado a intervir, dar a sua solução ao problema encenado. Nesse momento, ele assume outro 
papel: o de ator da ação dramática. O resultado dessa junção possibilita que, já assumindo a nomenclatura proposta por Boal - espect-ator -, ele possa vivenciar o ver a cena e o estar em cena. Essa última, portanto, direciona seu olhar na perspectiva de se colocar no lugar do outro, nesse caso, do oprimido, e poder, de fato, propor soluções para o conflito em questão.

Tais técnicas direcionam seus participantes ao limite entre a ficção e realidade, ao promoverem reflexões sobre as relações de poder; os direitos e deveres de convívio em sociedade; respeito às diferenças em nível de etnia, classe social, identidade de gênero, entre outras. Por meio do contato com a linguagem teatral é possível discutir esses temas que envolvem diretamente opressores e oprimidos, através de situações reais que são teatralizadas, acompanhadas de uma apreensão estética.

Boal em seu livro Teatro do Oprimido e outras poéticas políticas (2005) apresentou a linguagem teatral para aqueles que não a escolheram como profissão, tampouco não a prestigiavam como produção cultural. $\mathrm{O}$ que ele fez foi inserir o teatro como possibilidade de discussão, reflexão e transformação a segmentos sociais menos favorecidos culturalmente, economicamente e, por que não, intelectualmente. $\mathrm{O}$ teatro lhes foi apresentado como, além de um reduto de entretenimento, elemento de possibilidade de reflexão e de mudança.

Por esse motivo, dedicou-se a construir espaço junto com os que não encontravam lugar para suas histórias, aspirações e desejos. Segundo ele, não era possível defender a multiplicidade cultural por meio de uma única estética. Afinal, somos herdeiros da diversidade, logo, temos maneiras diferenciadas de nos colocar e dialogar com a realidade a nossa volta.

O símbolo que Boal escolheu para representar o arsenal do Teatro do Oprimido foi uma árvore, por estar em constante transformação e ter a capacidade de se multiplicar. A Ética é a base dessa árvore que se respalda na estrutura pedagógica criada por esse teatrólogo e cujo solo se alimenta de outras áreas do conhecimento, como a Filosofia, a História, a Política e a Economia, o que respalda seu trabalho na junção do artístico com o social.

As técnicas representadas em cada galho se Multiplicam através da Solidariedade, uma vez que, ao ter acesso ao arsenal do Teatro do Oprimido, é possível aplicá-lo em grupos sociais e em comunidades que necessitam transformar fatos 
cotidianos. Fatos esses que lhes causem opressão, assim como os tornam mais conscientes de seus direitos.

As ramificações presentes na raiz representam as três linguagens contidas nas Artes: a imagem, o som e a palavra - base da Estética do Oprimido - que, acompanhadas esteticamente, possibilitam perceber a sociedade por meio de outras perspectivas. As três juntas potencializam a discussão vivida em cena. Para Boal em $A$ Estética do Oprimido (2009, p.19):

Palavra, imagem e som, que hoje são canais de opressão, devem ser usados pelos oprimidos como formas de rebeldia e ação, não passiva contemplação absorta. Não basta consumir cultura: necessário é ser artista! Não basta produzir ideias: necessário é transformá-las em atos sociais, concretos e continuados. (...) Arte e estética são instrumentos de libertação.

No tronco, tem-se os Jogos que permitem, para aqueles que não são atores, vivenciarem práticas teatrais e, para todos que participam, desmecanizar o corpo cotidiano, promovendo, consequentemente, atos criativos e expressivos capazes de transformar o que os oprime. Os Jogos, como na vida, possuem regras estabelecidas que possibilitem agir com liberdade e responsabilidade em prol de um bem comum e de conquistas que elevem o sujeito a adquirir status sociais, econômicos e, por que não, políticos.

Os Jogos estão divididos em cinco categorias: sentir tudo que se toca, escutar tudo que se ouve, ativando os vários sentidos, sentir tudo que se olha e a memória dos sentidos. Boal fez essa divisão por acreditar que perdemos a totalidade dos sentidos com ações corriqueiras, levando o nosso corpo à atrofia. Ele entende que dividi-los é uma tentativa de senti-los em sua plenitude.

Nos galhos, têm-se as técnicas Teatro Jornal, Ações Diretas - que atualmente é denominada de Ações Sociais Concretas Continuadas -, Teatro Legislativo, Teatro Invisível e Arco-Íris do Desejo; no tronco, o Teatro-Fórum e Teatro Imagem. Essa ordem proporciona a visualização de duas técnicas que são o filtro de quatro em específico: Teatro Imagem faz ligação com Teatro Jornal e Arco-Íris do Desejo; Teatro-Fórum com Ações Diretas, Teatro Legislativo e Teatro Invisível; recebendo a influência de todas as outras técnicas, resumindo o arsenal do Teatro do Oprimido. 


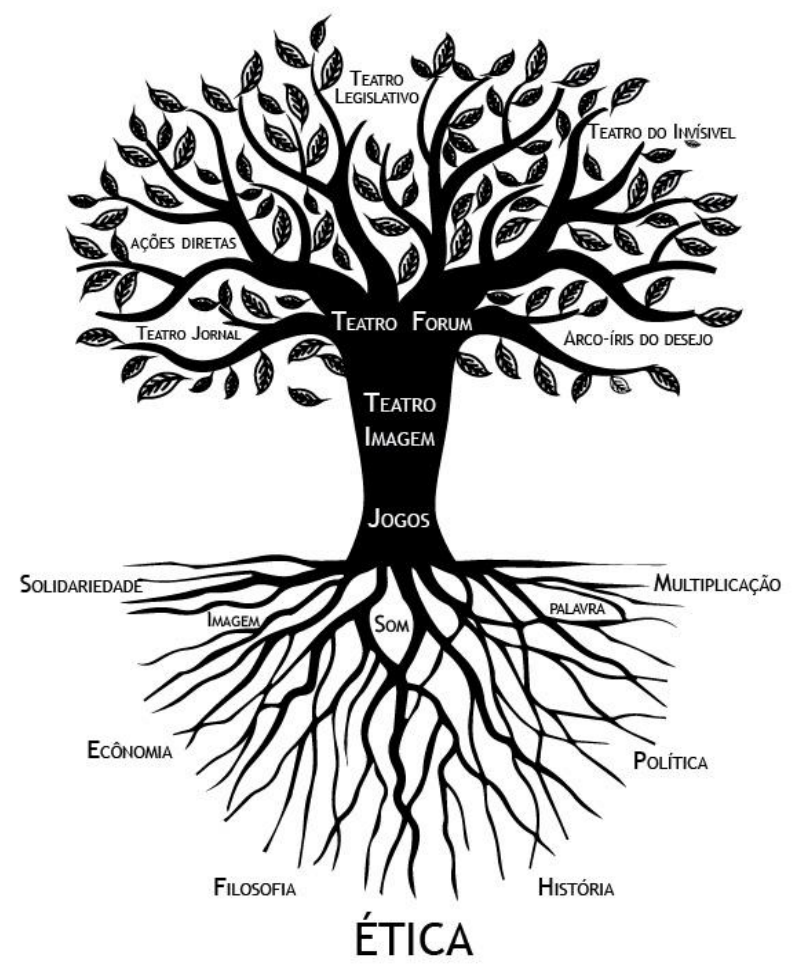

Fonte: http://sketchnerd.blogspot.com.br/2016/02/arvore-do-teatro-do-oprimido.html. Acesso em 10 de fevereiro de 2016

A seguir, apresento considerações sobre a Oficina de Teatro do Oprimido.

\section{1 - DESCRIÇÃO DA OFICINA OPRIERAM}

Cada etapa da oficina auxiliou na construção de uma produção artística pautada nas histórias compartilhadas pelo grupo e selecionadas para que pudessem ser teatralizadas, uma vez que a oficina visava à elaboração de um espetáculo-fórum, ou seja, um espetáculo aberto para o debate, com a participação da plateia para solucionar a problemática abordada em cena. Os problemas eram inscritos em situações cotidianas e conflituosas onde as relações de poder se evidenciavam.

Este grupo foi composto por 13 adolescentes (5 meninas e 8 meninos) que cursavam, em 2015, o $2^{\circ}$ e $3^{\circ}$ anos do Ensino Médio no Centro de Ensino Médio do Setor Oeste - CEM-SO - localizado na 913 Sul - região do Plano Piloto de Brasília - 
DF e o $3^{\circ}$ ano do Centro Educacional 03 do Guará - conhecido como CENTRÃO. A autorização da escola e dos pais para que os alunos participassem da oficina está em anexo.

A maior parte desses adolescentes havia vivenciado uma oficina de teatro no primeiro semestre de 2015 com três professores de Artes Cênicas - Aline Seabra, Hugo de Freitas e Ricardo Cruccioli. O processo resultou na montagem do espetáculo Dispase, projeto de pesquisa dos três arte-educadores que cursam, junto comigo, o Mestrado Profissionalizante em Teatro - PROF-ARTES.

Ao estar acompanhando parte do processo, fiquei motivada em realizar uma oficina de Teatro do Oprimido com esses adolescentes, por perceber a entrega e encanto que eles demonstraram pelo teatro, além da vontade de entender e se manifestar por meio da linguagem teatral. No semestre seguinte, eles aceitaram o convite de fazerem parte de minha pesquisa, com enfoque no Teatro-Fórum, o qual acredito ser um agente pontecializador no desenvolvimento de ações protagônicas.

A faixa-etária foi escolhida propositalmente por se tratar da adolescência período de transição: não são mais crianças e ainda não chegaram à fase adulta. Com isso, a vivência de uma oficina que trabalhasse seus posicionamentos diante das demandas dos jogos teatrais e da criação de um espetáculo fórum tinha o intuito de ajudá-los a se perceberem e se posicionarem como cidadãos em construção.

Segundo relata uma das participantes:

Acabamos essa oficina, já com a promessa de outra: Teatro do Oprimido e improviso. Apenas isso que entendemos apesar de toda a explicação-convite de uma tal Silvia, amiga dos nossos professores, que também precisava de uma turma para o mestrado (D. A., 17 anos).

Havia uma expectativa, da parte deles, de o que seria vivenciar uma oficina de Teatro do Oprimido, pois o termo - oprimido - lhes sugeria a ideia de submissão, de aceitação de uma condição inferior. Esclareci a eles que o oprimido é alguém que luta muito para alcançar seu objetivo, mas que, em algumas situações, o opressor é mais forte que ele. Frisei que construiríamos um espetáculo a partir de situações de opressão vindas por meio de suas histórias, auxiliadas com a vivência de jogos teatrais e de improvisos oriundos de temas pautados em suas indignações e reivindicações. 
A oficina foi ministrada no auditório e no teatro de arena da Escola Parque da 313/314 Sul, instituição onde sou professora de Teatro. Os encontros semanais aconteciam toda quinta-feira das $14 \mathrm{~h} 30$ às $18 \mathrm{~h}$ - durante três meses - de 13/08 a 08/12/15; somando um total de 26 encontros considerando-se o ensaio geral e as quatro apresentações que ocorreram nos dias 03, 04 e 05/12/15, no auditório da referida Escola Parque, e no dia 08/12/15 no Teatro Dulcina, outra instituição onde também leciono Teatro.

Realizei um cronograma de atividades que visou o entendimento e a experiência prática e teórica sobre o Teatro do Oprimido, acrescentando a trajetória de seu criador Augusto Boal -, assim como as repercussões que esse tipo de teatro teve e tem nos locais, cidades e países em que é praticado. O cronograma da oficina visava prepará-los para uma construção de saberes associado a conflitos inerentes à faixa etária em que eles se encontravam (16 a 18 anos) e que culminassem em seus anseios, sonhos, desejos e cobranças que ocorrem nesse período da adolescência.

A tabela a seguir, apresenta o cronograma com o planejamento dessa oficina.

\section{Oficina de Teatro do Oprimido - Oprieram}

\begin{tabular}{|c|c|c|c|}
\hline $\begin{array}{c}\text { Dias dos } \\
\text { Encontros }\end{array}$ & $\begin{array}{c}\text { Jogos Teatrais e } \\
\text { Apresentação de Cenas } \\
\end{array}$ & $\begin{array}{c}\text { Categoria dos Jogos } \\
\text { Teatrais } \\
\end{array}$ & $\begin{array}{c}\text { Horário da } \\
\text { Oficina } \\
\end{array}$ \\
\hline $\begin{array}{l}13 \text { de agosto } \\
\left(1^{\mathrm{o}} \text { encontro }\right)\end{array}$ & $\begin{array}{l}\text { - } \text { Batizado Mineiro; } \\
\text { - Roda de Ritmos } \\
\text { com variante; } \\
\text { - Máquina Rítmica. }\end{array}$ & $\begin{array}{l}\text { - } 2^{\mathrm{a}} \text { Categoria } \\
\text { - } 2^{\mathrm{a}} \text { Categoria } \\
\text { - } 2^{\mathrm{a}} \text { Categoria }\end{array}$ & $14 \mathrm{~h} 30$ a $18 \mathrm{~h} 30$ \\
\hline $\begin{array}{l}20 \text { de agosto } \\
\left(2^{\circ} \text { encontro }\right)\end{array}$ & $\begin{array}{l}\text { - Completar a } \\
\text { Imagem com } \\
\text { variante; } \\
\text { - Relatos do Tema: } O \\
\text { que mais me } \\
\text { indigna? }\end{array}$ & - $4^{\mathrm{a}}$ Categoria & $14 \mathrm{~h} 30$ a $18 \mathrm{~h} 30$ \\
\hline $\begin{array}{l}27 \text { de agosto } \\
\left(3^{\circ} \text { encontro }\right)\end{array}$ & $\begin{array}{l}\text { Apresentação das } \\
\text { cenas individuais: } \\
\text { Se eu pudesse } \\
\text { mudar alguma } \\
\text { coisa, o que eu } \\
\text { mudaria? }\end{array}$ & \#\#\# & $14 \mathrm{~h} 30$ a $18 \mathrm{~h} 30$ \\
\hline
\end{tabular}




\begin{tabular}{|c|c|c|c|}
\hline $\begin{array}{l}03 \text { de setembro } \\
\left(4^{\circ} \text { encontro }\right)\end{array}$ & - Floresta de Sons. & - $3^{\mathrm{a}}$ Categoria & $14 \mathrm{~h} 30$ a $18 \mathrm{~h} 30$ \\
\hline $\begin{array}{l}10 \text { de setembro } \\
\left(5^{\circ} \text { encontro }\right)\end{array}$ & $\begin{array}{l}\text { - Floresta de Sons } \\
\text { com variante; } \\
\text { - Quantos "as" } \\
\text { existem em um } \\
\text { "a"? } \\
\text { - O círculo de nós. }\end{array}$ & $\begin{array}{l}\text { - } 3^{\mathrm{a}} \text { Categoria } \\
\text { - } 2^{\mathrm{a}} \text { Categoria } \\
\text { - } 1^{\mathrm{a}} \text { Categoria }\end{array}$ & $14 \mathrm{~h} 30$ a $18 \mathrm{~h} 30$ \\
\hline $\begin{array}{l}17 \text { de setembro } \\
\left(6^{\circ} \text { encontro }\right)\end{array}$ & $\begin{array}{l}\text { - Um, Dois, Três de } \\
\text { Bradford; } \\
\text { - Fotografar a } \\
\text { Imagem com } \\
\text { variante; } \\
\text { - Improvisação: Meu } \\
\text { sonho é...? } \\
\text { - Homenagem a } \\
\text { Magritte. }\end{array}$ & $\begin{array}{l}\text { - } 2^{\mathrm{a}} \text { Categoria } \\
\text { - } 4^{\mathrm{a}} \text { Categoria } \\
\text { - } 4^{\mathrm{a}} \text { Categoria }\end{array}$ & $14 \mathrm{~h} 30$ a $18 \mathrm{~h} 30$ \\
\hline $\begin{array}{l}24 \text { de setembro } \\
\left(7^{\circ} \text { encontro }\right)\end{array}$ & $\begin{array}{l}\text { - Hipnotismo } \\
\text { Colombiano; } \\
\text { - } \quad \text { A luta de Galos. }\end{array}$ & $\begin{array}{l}\text { - } 1^{\mathrm{a}} \text { Categoria } \\
\text { - } \quad 4^{\mathrm{a}} \text { Categoria } \\
\end{array}$ & $14 \mathrm{~h} 30$ a $18 \mathrm{~h} 30$ \\
\hline $\begin{array}{l}01 \text { de outubro } \\
\left(8^{\circ} \text { encontro }\right)\end{array}$ & $\begin{array}{l}\bullet \quad \text { Leitura } \\
\text { Dramática: } \text { Murro } \\
\text { em } \text { Ponta de } \\
\text { Faca. }\end{array}$ & \#\#\# & $14 \mathrm{~h} 30$ a $18 \mathrm{~h} 30$ \\
\hline $\begin{array}{l}08 \text { de outubro } \\
\left(9^{\circ} \text { encontro) }\right.\end{array}$ & $\begin{array}{l}\text { - Vídeos e textos } \\
\text { sobre Boal. } \\
\text { - Quatro em marcha; } \\
\text { - O Jogo do Poder. } \\
\text { - Proposta de cena. }\end{array}$ & $\begin{array}{l}\text { \#\#\# } \\
\text { - } 5^{\mathrm{a}} \text { Categoria } \\
\text { - } 4^{\mathrm{a}} \text { Categoria } \\
\end{array}$ & $14 \mathrm{~h} 30$ a $18 \mathrm{~h} 30$ \\
\hline $\begin{array}{l}15 \text { de outubro } \\
\left(10^{\circ} \text { encontro }\right)\end{array}$ & $\begin{array}{l}\text { - Discussão sobre a } \\
\text { peça Revolução da } \\
\text { América do Sul. }\end{array}$ & \#\#\# & $14 \mathrm{~h} 30$ a $18 \mathrm{~h} 30$ \\
\hline $\begin{array}{l}22 \text { de outubro } \\
\left(11^{\circ} \text { encontro }\right)\end{array}$ & - Canovaccio. & \#\#\# & $14 \mathrm{~h} 30$ a $18 \mathrm{~h} 30$ \\
\hline $\begin{array}{l}29 \text { de outubro } \\
\left(12^{\circ} \text { encontro }\right)\end{array}$ & - Canovaccio. & \#\#\# & $14 \mathrm{~h} 30$ a $18 \mathrm{~h} 30$ \\
\hline $\begin{array}{c}05 \text { de novembro } \\
\left(13^{\circ} \text { encontro }\right)\end{array}$ & - Prévia do Roteiro. & \#\#\# & $14 \mathrm{~h} 30$ a $18 \mathrm{~h} 30$ \\
\hline $\begin{array}{l}07 \text { de novembro } \\
\left(14^{\circ} \text { encontro }\right)\end{array}$ & - Ensaio do Roteiro. & \#\#\# & $09 \mathrm{~h}$ a $13 \mathrm{~h}$ \\
\hline $\begin{array}{l}12 \text { de novembro } \\
\left(15^{\circ} \text { encontro }\right)\end{array}$ & $\begin{array}{l}\text { - Modificações no } \\
\text { Roteiro. }\end{array}$ & \#\#\# & $14 \mathrm{~h} 30$ a $18 \mathrm{~h} 30$ \\
\hline $\begin{array}{c}14 \text { de novembro } \\
\left(16^{\circ} \text { encontro }\right)\end{array}$ & - Ensaio do Roteiro. & \#\#\# & $09 \mathrm{~h}$ a $13 \mathrm{~h}$ \\
\hline $\begin{array}{l}19 \text { de novembro } \\
\left(17^{\circ} \text { encontro }\right)\end{array}$ & $\begin{array}{l}\text { - Criação de novas } \\
\text { Cenas. }\end{array}$ & \#\#\# & $14 \mathrm{~h} 30$ a $18 \mathrm{~h} 30$ \\
\hline
\end{tabular}




\begin{tabular}{|c|c|c|c|}
\hline $\begin{array}{l}21 \text { de novembro } \\
\left(18^{\circ} \text { encontro }\right)\end{array}$ & - Ensaio do Roteiro. & \#\#\# & $09 \mathrm{~h}$ a $13 \mathrm{~h}$ \\
\hline $\begin{array}{l}26 \text { de novembro } \\
\left(19^{\circ} \text { encontro }\right)\end{array}$ & $\begin{array}{l}\text { - Definição das } \\
\text { Cenas. }\end{array}$ & \#\#\# & $14 \mathrm{~h} 30$ a $18 \mathrm{~h} 30$ \\
\hline $\begin{array}{l}28 \text { de novembro } \\
\left(20^{\circ} \text { encontro }\right)\end{array}$ & - Ensaio das Cenas. & \#\#\# & $09 \mathrm{~h}$ a $13 \mathrm{~h}$ \\
\hline $\begin{array}{l}02 \text { de dezembro } \\
\left(21^{\circ} \text { encontro }\right)\end{array}$ & $\begin{array}{l}\text { - Ensaio Geral } \\
\text { com Iluminação e } \\
\text { Figurino. }\end{array}$ & \#\#\# & $14 \mathrm{~h} 30$ a $20 \mathrm{~h} 30$ \\
\hline $\begin{array}{l}03 \text { de dezembro } \\
\left(22^{\circ} \text { encontro }\right)\end{array}$ & $\begin{array}{l}\text { - Apresentação } \\
\text { Escola Parque. }\end{array}$ & \#\#\# & $14 \mathrm{~h} 30$ a $22 \mathrm{~h} 30$ \\
\hline $\begin{array}{c}04 \text { de dezembro } \\
\left(23^{\circ} \text { encontro }\right)\end{array}$ & $\begin{array}{l}\text { Apresentação } \\
\text { Escola Parque. }\end{array}$ & \#\#\# & $14 \mathrm{~h} 30$ a $22 \mathrm{~h} 30$ \\
\hline $\begin{array}{l}05 \text { de dezembro } \\
\left(24^{\circ} \text { encontro }\right)\end{array}$ & $\begin{array}{l}\text { - Apresentação } \\
\text { Escola Parque. }\end{array}$ & \#\#\# & $14 \mathrm{~h} 30$ a $22 \mathrm{~h} 30$ \\
\hline $\begin{array}{l}08 \text { de dezembro } \\
\left(25^{\circ} \text { encontro }\right)\end{array}$ & $\begin{array}{l}\text { - Apresentação } \\
\text { Teatro Dulcina. }\end{array}$ & \#\#\# & $14 \mathrm{~h} 30$ a $22 \mathrm{~h} 30$ \\
\hline \multirow[t]{2}{*}{$\begin{array}{l}10 \text { de dezembro } \\
\left(26^{\circ} \text { encontro }\right)\end{array}$} & $\begin{array}{l}\text { - Avaliação da } \\
\text { Oficina. }\end{array}$ & $\begin{array}{l}\text { - Entrega do } \\
\text { Certificado. }\end{array}$ & $14 \mathrm{~h} 30$ a $18 \mathrm{~h} 30$ \\
\hline & & Total de: & 112 horas/aula \\
\hline
\end{tabular}

Os primeiros jogos aplicados na oficina estão classificados na segunda categoria - escutar tudo que se ouve - por propiciar ritmo, movimento e entrosamento entre o grupo a partir das regras estabelecidas em cada jogo. Boal nos chama a atenção para: nem tudo que escutamos, ouvimos. Talvez pelo fato de desde pequenos sermos criados com regras, com isso, nosso corpo se limita a executar normas pré-estabelecidas ou socialmente aceitáveis. O momento dos jogos propicia essa desmecanização e o corpo fica livre para se expressar e, de fato, exercitar seus sentidos e que o grupo produz.

Maria Lúcia Pupo, em sua pesquisa sobre Palavras em jogo: textos literários e teatro (1997), analisa a existência de regras precisas que estabelecem eixos abertos para as composições em cena que, a depender do grupo, são encaminhadas para os temas propostos. Essas regras se destacam em quatro princípios comuns entre o jogo dramático e o jogo teatral, que para a autora são:

$1^{\mathrm{o}}$ - Prescindem da noção de talento ou de qualquer prérequisito anterior ao próprio ato de jogar;

$2^{\mathrm{o}}$ - Na medida em que visam ao desenvolvimento da capacidade de jogo numa perspectiva de comunicação teatral, tem na plateia - interna ao próprio grupo de 
jogadores - um elemento essencial para avaliação do crescimento dos participantes;

$3^{\circ}$ - A partir de propostas estruturais, derivadas da linguagem teatral, possibilitam que desejos, temas, situações de jogo emerjam do próprio grupo;

$4^{\circ}$ - Permitem que o grau de envolvimento do grupo no fazer teatral seja definido por ele próprio em função de sua motivação e de suas possibilidades. (PUPO, 1997, p. $10)$.

Embora Pupo e Boal tenham objetivos diferentes em relação à utilização da linguagem teatral, percebo um diálogo entre esses quatro princípios em destaque com a proposta do criador do Teatro do Oprimido, no que se refere a prática teatral para atores e não atores, ao evidenciar que cada jogo teatral estimula os participantes à criação individual e coletiva concomitantemente. A gênese flui em razão do encontro com o lúdico, no sentido de despertar a intuição e a descoberta da expressão que se sobrepõem às regras contidas nos jogos teatrais.

\section{2 - DESCRIÇÃO DOS JOGOS TEATRAIS}

\section{$1^{\circ}$ Encontro - 13 de agosto de 2015.}

\section{1 - Batizado Mineiro - 2a Categoria-escutar tudo que se ouve}

Descrição - Normalmente é o primeiro jogo aplicado em uma oficina de Teatro do Oprimido, por ser um exercício em que os participantes se apresentam. Essa apresentação ocorre de forma lúdica: não basta dizer apenas o prenome, mas tem que dizê-lo fazendo um som e um ritmo acrescentando uma qualidade que inicie com a primeira letra da palavra proferida. Se o nome do participante for "Wilson", por exemplo, ele procurará uma qualidade que comece com W. Caso ele não a encontre - já que é uma letra que foi acrescentada ao nosso alfabeto brasileiro -, opta-se pelo som que essa letra emite: "Uilson" - então será uma qualidade que comece com a letra "U”.

Objetivo - Nesse tipo de jogo, o participante é "batizado" na vivência cênica e descobre que seu corpo, ao ser estimulado, produz som e ritmo.

Resultados - Desperta a atitude em assumir sua identidade e qualidades ligadas a si com a inicial de seu nome. Esse é um modo de se afirmar perante o grupo e também de 
conhecer o outro, que divide o mesmo "espaço cênico", além de observar como todos os participantes se veem.

\section{2 - Roda de Ritmos}

Descrição - Nesse jogo, como o próprio nome esclarece, é feita uma roda e um participante vai até o centro dela e executa um movimento e som ininterrupto, os quais serão posteriormente repetidos por todos. Após isso, ele vai em direção a alguém e assume o seu lugar, e o escolhido vai para o centro da roda ainda fazendo o movimento junto com os demais, até chegar ao centro e propor seu movimento, preferencialmente, diverso do anterior.

Depois de um tempo - no centro - e todos o imitando, este vai em direção de outro participante na grande roda e assume o seu lugar, enquanto o outro se dirige ao centro para assim propor seu movimento. O jogo finaliza quando todos, um por um, criam o seu som e movimento no centro da roda, servindo como se fosse um líder para os demais. É o que Boal observa em Jogos para atores e não-atores (2006, p. 127): "Imitando os outros, estaremos reestruturando de várias maneiras diferentes nossa própria maneira de ser e de agir".

\section{1 - Roda de Ritmos com variante (Helen)}

Descrição - A variante desse jogo foi criada por Helen Sarapeck - Diretora Artística do Centro de Teatro do Oprimido - como proposta de continuidade da Roda de Ritmos, visto que os participantes ficavam muito empolgados e a variante contribuiu a esse envolvimento. Nesse exercício, o último que se dirige ao centro da roda permanece na frente, em destaque, e os demais ficam espalhados atrás dele formando um coro. Até que, quem quiser, se desloque para frente desse, em destaque, e propõe outro som e movimento; os demais podem escolher entre permanecer atrás do primeiro participante ou ficar atrás do segundo. E assim sucessivamente, como em um duelo, no qual o grupo decide seguir o movimento e som que mais o surpreenda e agrade.

Objetivo - Consciência de que o corpo produz som e ritmo. E, ao trabalhar em grupo, desenvolve-se a interação necessária para as próximas demandas teatrais. 
Resultados - Ao final do jogo, todos estão aquecidos e desmecanizados de um corpo acostumado às ações cotidianas, ou seja, corpos condicionados às regras e funções préestabelecidas. Os participantes se soltam, voltam a "brincar e sorrir"; sem dúvida é um jogo que contagia e une o grupo.

Os jogos inseridos no arsenal do Teatro do Oprimido podem ser incrementados, adaptados, dependendo da necessidade do grupo em que se desenvolve o trabalho. Assim, os multiplicadores têm a liberdade de criar, acrescentar novos exercícios aos já existentes. Boal denominou-o como variante. Essa possibilidade de reestruturação nos jogos permite que o multiplicador se atente ao grupo e perceba suas necessidades e as demandas que, em parte, podem ser supridas com a variação de alguns jogos, a fim de que o grupo possa responder com corpo e expressões questões referentes a si e ao outro.

\section{3 - Máquina Rítmica}

Descrição - Consiste na engrenagem de uma máquina em ação, na qual cada participante é uma peça. A forma de representá-la é criar um movimento rítmico seguido de um som no centro da roda. Depois, um por um vai executando seu movimento como se complementasse o anterior, até que todos estejam compondo a máquina de forma complexa e harmônica. O primeiro que inicia o movimento torna-se uma espécie de líder, que depois dita o ritmo da máquina: hora mais rápida, hora mais lenta, até congelar quando quem está conduzindo o jogo pede o encerramento. Todos têm que estar atentos ao movimento do líder, um exercício de escutar tudo que se ouve.

Nesse jogo, propõem-se três etapas de início: a Máquina Sem Tema - cada um realiza um som e um movimento ininterrupto e vai compondo a máquina aleatoriamente; a Máquina do Amor e a Máquina do Ódio - essas duas também têm o mesmo comando, a diferença é que o movimento deixa de ser aleatório, ao ser estimulado pelo tema sugerido pelo multiplicador. Portanto, cada multiplicador pode acrescentar temas, dependendo da demanda do grupo que se está realizando o trabalho.

Objetivo - Ao aplicar esse jogo, observa-se a criatividade, espontaneidade e a primeira expressividade de cada participante sobre o tema. Como continuidade a essas observações, acrescentei a Máquina do Brasil, a Máquina de Brasília e, para encerrar, a Máquina do Adolescente. 
Resultados - Após a Máquina "pronta" por cada peça humana, incitei-os a refletir sobre que movimentos e sons o grupo produziu. Na do Amor, por exemplo, o grupo demorou a entrar no jogo, pensativo sobre qual movimento poderia expressar o amor. Diferente da primeira, que foi ausente de uma temática, os participantes logo foram propondo sons, movimentos e ritmos ao compor a máquina.

Ao comparar os tipos de movimentos referentes às duas máquinas, o primeiro participante seguiu sem perspectiva, sem intenção, apenas sendo uma peça aleatória que, somada às outras, dava a ideia de uma máquina em funcionamento. Já o segundo, por ter um tema estabelecido, trouxe expressões com intenções, os movimentos se tornaram mais precisos e condizentes. Ali surgiram personagens com ações definidas.

O que pude perceber nos grupos em que tenho aplicado esse jogo é que o participante iniciador do jogo no centro da roda, ao realizar seu movimento, influencia os demais. Nesta oficina, por exemplo, o primeiro adolescente que executou seu movimento ininterrupto o fez associando o amor ao sexo, ao priorizar sons e expressividades corporais que remetiam ao ato sexual. Com isso, os outros que foram compondo a Máquina fizeram expressões e sons parecidos com o líder - como é chamado o primeiro participante que inicia o jogo. Ele também determina o ritmo da máquina quando todos já entraram no centro da roda com suas respectivas peças, ou seja, movimentos/sons. Após um tempo em que todos compuseram a Máquina do Amor, finalizei o jogo pedindo que congelassem, se olhassem e, depois, voltassem para o círculo inicial.

Nesse momento, perguntei o que eles acharam da construção que fizeram juntos, onde cada peça com sua especificidade de movimentos, sons e ritmos produziram uma máquina que, diferente da primeira, tinha um tema. Isso suscitou em cada participante uma breve reflexão sobre como poderiam representar, no corpo, o entendimento sobre o amor (tema sugerido) e, ao mesmo tempo, sobre quando algumas vezes somos levados pela opinião alheia, em vez de valorizar a nossa.

Digo isso em relação à maior parte dos participantes que fizeram sua expressividade influenciada pelo líder. Se este tivesse feito um movimento mais suave reportando-se ao amor romântico, por exemplo, o grupo em sua maioria teria feito uma máquina mais leve, menos provocante. É preciso se posicionar diante de um desafio e acreditar na sua ideia. Também é importante reconhecer quando o seu movimento foi 
influenciado pelo outro; isso demonstra que às vezes encontramos no outro o que queremos dizer.

Já na Máquina do Ódio, a pausa dada entre o pensar o movimento e o executá-lo, no centro da roda, foi bem mais rápida que na da Máquina do Amor. Depoimentos coincidiram quanto à realidade de que expressar o ódio por alguém ou por situações é mais fácil do que expressar o amor. E eu destaquei como o nosso corpo reage mais rapidamente a sensações que nos causam raiva, indignação, intolerância, lembranças ruins... Parece que estamos mais suscetíveis a esse tipo de sentimento. Talvez seja uma reação corpórea aos conflitos sociais que vivenciamos em nosso cotidiano.

As duas Máquinas subsequentes foram a do Brasil e a de Brasília, cuja intenção era observar que imagem eles tinham do seu país e da capital brasileira onde residiam. Parecido com o que aconteceu na do Amor, boa parte do grupo foi influenciada pelo líder, que ressaltou o modo como muitos veem o Brasil: o país do samba e do futebol. Contudo, uma minoria expressou outro lado do país: daquele que batalha, que vai para as ruas protestar, do que usa a criatividade para sobreviver e também do que sofre com a violência e a desigualdade social. No término de cada máquina, voltamos para a roda inicial e refletimos sobre como cada participante se expressava a partir do tema sugerido.

Assim como na roda do Brasil, os alertei em relação à influência do líder e percebi que, na de Brasília, eles tiveram o cuidado de não serem influenciados: cada um expôs sua visão sobre a cidade onde moravam de modo isolado, sem prestar atenção em como o colega se expressava. Na tentativa de não sofrer influências, eles acabaram por se isolar em um jogo que requer o trabalho em grupo, isto é, cada peça precisa da outra para compor a máquina como um todo. Alguns reforçaram por meio de seus corpos o "discurso" comumente feito sobre Brasília como: a capital da corrupção; monumentos apoteóticos; pessoas focadas em estudar e se tornar funcionárias públicas. Em contrapartida, outros salientaram, em seus movimentos, uma Brasília artística, politizada, mística e que agrega diferentes grupos culturais.

O que me chamou atenção foi vê-los em seus sons e expressões sem se olharem, se tocarem, isolados, sem a comunhão que o jogo propõe. Poderia até remetê-los a uma crítica que se faz comumente aos brasilienses de que as pessoas não se cumprimentam nos elevadores, nas ruas e que, muitas vezes, sequer conhecem o vizinho do apartamento ao lado, por exemplo; porém percebi que o isolamento se deu em uma 
tentativa de não repetir a influência que o líder exerceu no grupo durante o tema anterior. Com isso, saíram de um extremo para o outro. Um participante concluiu que eles erraram na tentativa de acertar e eu disse que não, pois não há erro nesse tipo de jogo, apenas formas diferenciadas de jogá-lo e de associá-lo ao cotidiano de cada um. E que o modo como jogamos pode ser comparado com o modo como lidamos com a nossa vida.

A última Máquina foi a do Adolescente. Acredito que pelas observações anteriores, eles a executaram no coletivo, mais conscientes do que queriam transmitir com a escolha de seus movimentos/sons/ritmos. Alguns optaram pela aprovação no vestibular, outros pelo namoro, pelo trabalho e pela vaidade exacerbada. O/A líder ditou o ritmo da máquina mas, diferentemente dos temas anteriores, não influenciou o grupo. Cada participante se expressou com mais independência, com mais legitimidade de como poderia exprimir, através do corpo em movimento, o que é ser adolescente, sem se esquecer do coletivo.

Para o primeiro dia de oficina, eles vivenciaram jogos que refletem seu posicionamento consigo, com o outro e em como veem a sociedade em si. Perceberam que os jogos do Teatro do Oprimido tem um cunho político, no sentido de fazê-los se posicionarem assiduamente. Como Boal acrescenta: "É extraordinário como a ideologia de um grupo, suas ideias políticas, etc., podem se revelar em ritmo físico e sonoro. Tudo aquilo que pensamos e criticamos aparece" (2006, p. 130). Assim, o processo começa a ser construído, de modo que cada jogo é uma alavanca para as vozes se manifestarem nos momentos em que forem solicitadas.

\section{$2^{\circ}$ Encontro - 20 de agosto de 2015.}

\section{1 - Completar a Imagem $-4^{\text {a }}$ Categoria - ver tudo que se olha}

Descrição - O jogo começa dividindo o espaço em dois ambientes: um é o palco e o outro é onde se situa a plateia. Convidei dois participantes para ocuparem o espaço cênico, um de frente para o outro, em cada extremidade do palco, com a mão direita estendida como se fosse cumprimentar alguém e ambos com o sorriso no rosto. Peço pra eles caminharem e, ao chegarem ao centro do palco, se cumprimentarem. Ao apertarem as mãos, pedi que congelassem. 
Nesse jogo, minha função se divide em conduzir o exercício e instigar a plateia sobre as possíveis interpretações referentes às duas imagens que ocupam o espaço/palco. Alguns disseram que são dois empresários se cumprimentando após fechar um negócio; outros disseram que parecem amantes que acabaram de fazer as pazes; ou pai e filho se despedindo e assim por diante. Esses são alguns exemplos de como o aperto de mãos entre duas pessoas gera infinitas interpretações, ou seja, as imagens dialogam entre si e são polissêmicas.

Depois um dos participantes se afasta e o outro fica ainda com a mão estendida e imóvel. Perguntei para o restante do grupo que imagem ele transmitia agora sozinho no espaço. Os que se manifestaram disseram que estava dando sinal para atravessar a faixa de pedestre; ou abrindo a porta de casa; ou esperando contribuições dos transeuntes; enfim, nessa imagem as interpretações foram diferentes da anterior, porém ambas estabeleceram diálogo com a plateia e geraram interpretações diferenciadas.

O outro participante retorna, olha para a imagem que continua imóvel, propõe outra e congela. $\mathrm{O}$ anterior sai da imagem em que estava, observa a que o colega fez, propõe outra e, assim, sucessivamente. A plateia observa a dupla que, ao revezar as imagens, constrói personagens e situações dando margem para leituras diferenciadas por parte da plateia. Depois troquei a dupla e outras imagens, personagens, situações e interpretações foram sendo formadas. Após as duas demonstrações, pedi que todos formassem duplas, ocupassem o palco, se cumprimentassem apertando as mãos ficando imóveis para que o jogo começasse.

No início eu dava o comando de troca - para que o primeiro da dupla iniciasse o jogo fazendo a imagem e congelasse em seguida para que o outro completasse com outra, mantendo-se imóvel logo após -, até o próximo comando de troca para o primeiro propor outra imagem a partir do que o segundo fez, e assim por diante. Porém, depois de um tempo realizando o exercício, deixei que cada dupla ditasse seu ritmo e trocasse as imagens por conta própria.

Com isso os participantes adquiriram autonomia diante da regra do jogo, mantendo o diálogo com o parceiro na medida em que intensificavam suas expressões, deixando mais clara sua intenção com a imagem realizada. A figura 1 a seguir ilustra essa atividade com o registro de algumas fotos $(1,23,4$ e 5$)$. 
Figura 1 - Exercício Completar a Imagem.
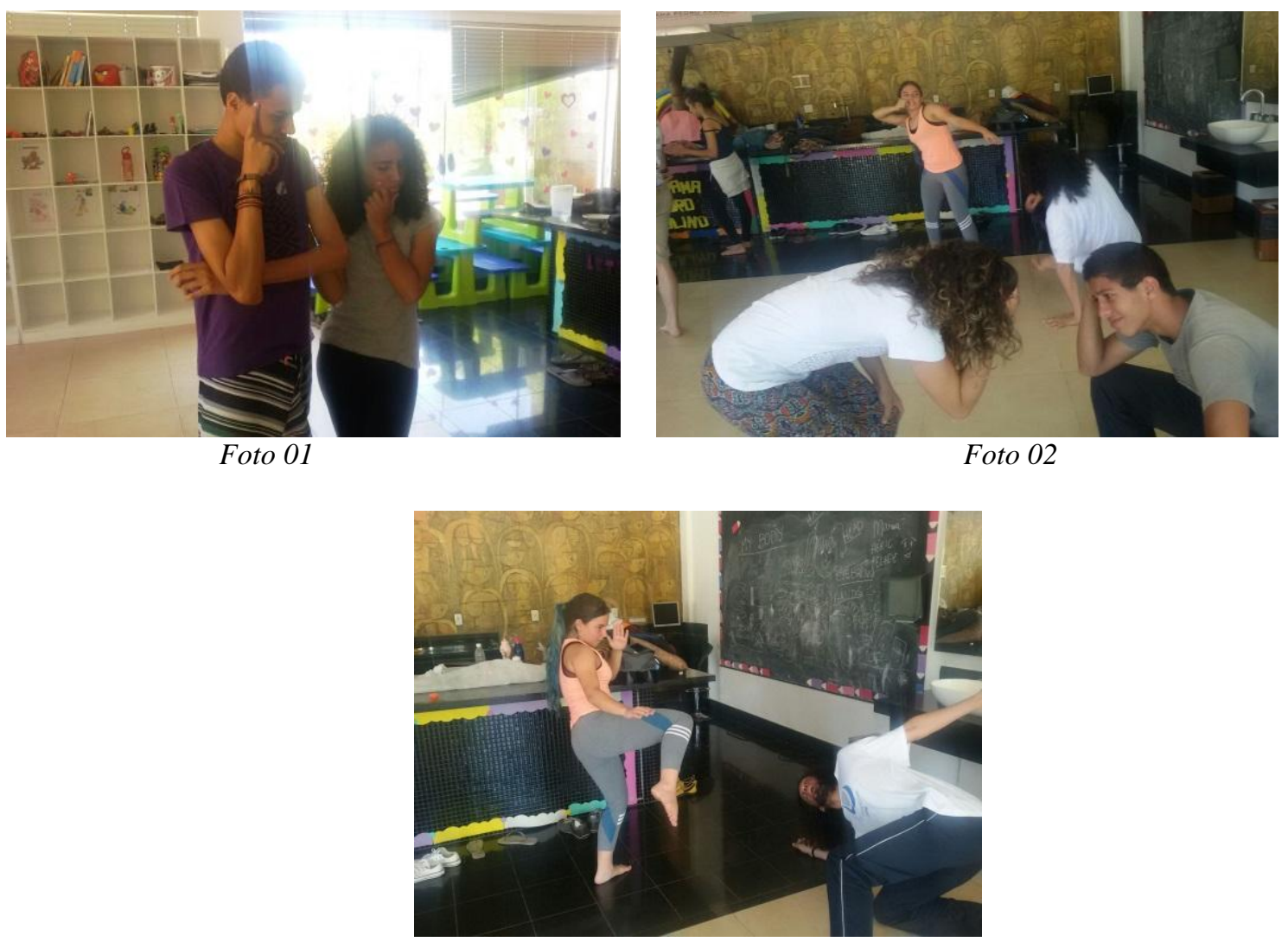

Foto 03

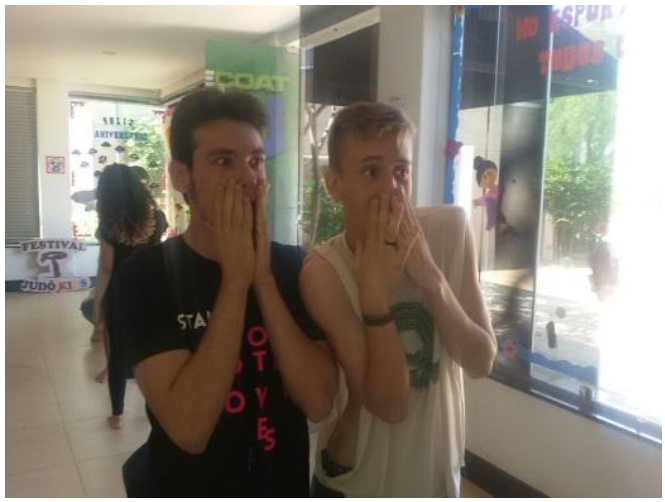

Foto 04

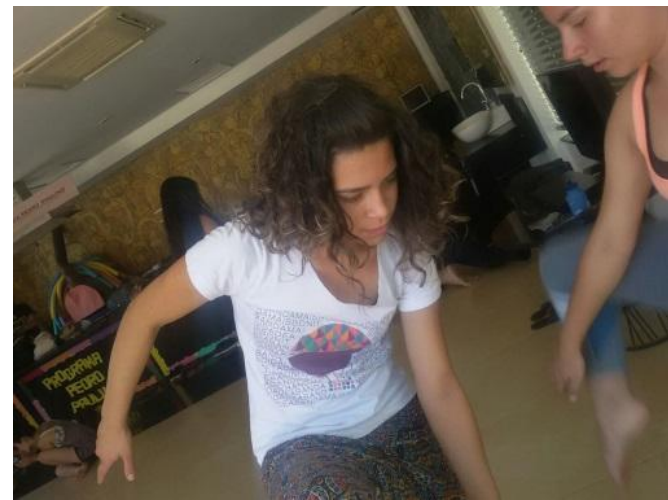

Foto 05

Fotografias de Silvia Paes - Arquivo da Autora

Objetivo - Esse exercício capacita o corpo a dialogar sem o uso da palavra, permitindo, portanto, que a expressividade corporal e facial realize a comunicação em sua totalidade. Quando a palavra for inserida mais adiante, ela será estritamente necessária, jamais explicativa, pois o corpo a acompanha na comunicação em cena.

$\mathrm{Na}$ quarta categoria, há exercícios que pertencem ao Teatro-Imagem, uma preparação para a demonstração de Teatro-Fórum. Essa técnica surgiu quando Boal realizou um trabalho com indígenas no Chile em que a comunicação por meio de 
palavras tornou-se ambígua, ou seja, gerando interpretações equivocadas. Com isso, ele passou a eliminar a palavra falada, priorizando imagens corporais em cena, de modo que a comunicação fosse estabelecida. As imagens são polissêmicas a partir do ângulo de quem as vê e é possível expressá-las intencionalmente com exercícios que demonstram situações e personagens.

Com a criação do Teatro Imagem, Boal buscou aperfeiçoar o sentido da visão, ampliando o significado do que vemos. Segundo ele, olhar é diferente de ver; o que nossos olhos enxergam não é o que a imagem nos diz, o que está por trás da imagem nos passa despercebido, pois nos ligamos ao externo dela. O nosso olhar, à primeira vista, ofusca leituras metafóricas de personagens e situações. Como o autor analisa em seu livro Técnicas Latino Americanas de Teatro-Popular (1988, p. 34).

Essa necessidade baseia-se, porém, na enorme diferença que existe entre olhar e ver. Estamos habituados a usar nossos olhos para olhar tudo e sempre, mas, em geral, vemos muito pouca coisa... A publicidade, sobretudo, nos habitua a olhar sem ver. Habitua-nos a associações de imagens impossíveis, contraditórias, antagônicas, irreconciliáveis. (...) Estamos habituados a olhar imagens que não nos deixam ver outras imagens, as quais poderiam passar diferentes informações.

Resultados - Em suas expressões, é possível perceber que eles se inserem em um contexto de personagens reagindo a situações. E que as imagens se completam ao assumir vertentes que dialogam com os princípios presentes nos jogos teatrais, a saber: foco, visualização, imaginação, concentração, fé cênica, intenção, objetivo de cena e ação - reação.

\section{1 - Completar a Imagem com variante (Silvia)}

Descrição - Eu criei uma variante nesse jogo que consiste em dividir os participantes em grupos e dar-lhes um tema para que seja desenvolvido em três imagens coletivas. As duas primeiras são estáticas, como se fosse uma foto que traduzisse a expressão do grupo sobre o tema dado. A terceira e última é uma imagem em movimento, ou seja, ela inicia de uma forma, reage à proposta em câmera lenta até finalizar a sequência de movimentos. Os temas sugeridos foram Papuda, Shopping e Praia. 
Objetivo - A intenção era mostrar que um mesmo tema, nesse tipo de jogo, pode ser artisticamente abordado de diversas maneiras, e que a escolha de um grupo, de certa forma, perpassa pelo modo como ele analisa a temática. E, ao se tratar da terceira imagem, suas ações, em princípio imóveis, geram consequências e resultados, pois a imagem inicial se modifica e gera outro resultado com a imagem final.

Resultados - Interessante constatar como um tema permite múltiplos significados e que nele está intrínseco microtemas que o situam em uma rede de relações e de opiniões, tanto daqueles que observam como daqueles que vivenciam. As leituras sobre os temas/lugares sugeridos enriqueceram-se de singularidades e redes de poder, no qual ficaram claras as situações de opressão ditas através das imagens realizadas em coletivo pelos participantes.

\section{2 - Relato: "O que mais me indigna?"}

Descrição - Uma cena individual a partir desse tema.

Objetivo - Ter conhecimento a respeito de suas indagações e indignações; assim identificam-se relações de poder e opressão com o intuito de serem trabalhadas para a construção do Teatro-Fórum.

Resultados - Os primeiros relatos foram em torno do universo infantil. Como exemplo: as relações conflituosas que alguns tiveram e ainda têm com os pais; a questão de abandono; de terem sido indesejados durante a gravidez e, em um caso específico, de ter sido recusado pelos pais aos oito meses de vida.

Que mal um bebê de oito meses pode fazer? E olha que eu era loirinho, tenho certeza que eu era uma gracinha. Por que meus pais não me quiseram? Eles me deram para os meus padrinhos, que, pra mim, são os MEUS PAIS. (T. N., 17 anos).

Esse relato emocionou a todos. Primeiro pela coragem do adolescente (foto 06) em falar sobre o assunto, no qual era nítida a dificuldade e emoção ao expor sua história. Segundo, pela confiança a mim e a todos do grupo, ao revelar fatos da sua infância (foto 07) quando, para aqueles que convivem com ele, a história era outra; provavelmente uma que fosse mais aceita, menos absurda, mais tolerante de conviver, 
um faz de conta necessário. Inclusive, alguns do grupo que estudam com ele desde o jardim de infância estavam impressionados diante da história verídica, pois sempre acreditaram que ele era filho adotivo. A pergunta naquela tarde foi respondida: o que mais indignava esse adolescente era a rejeição, o abandono.

Figura 2 - Cenas do espetáculo: Transições de Impacto.

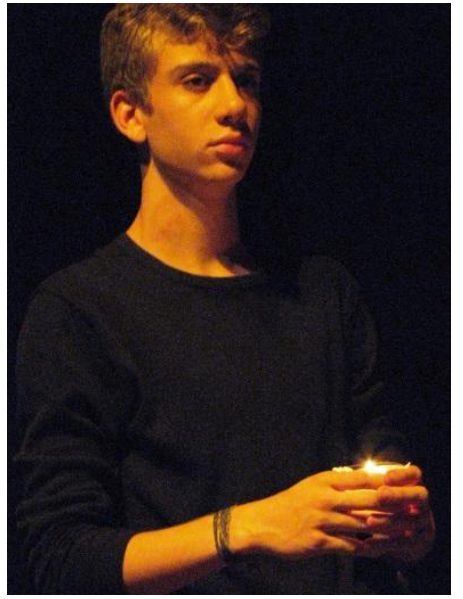

Foto 06

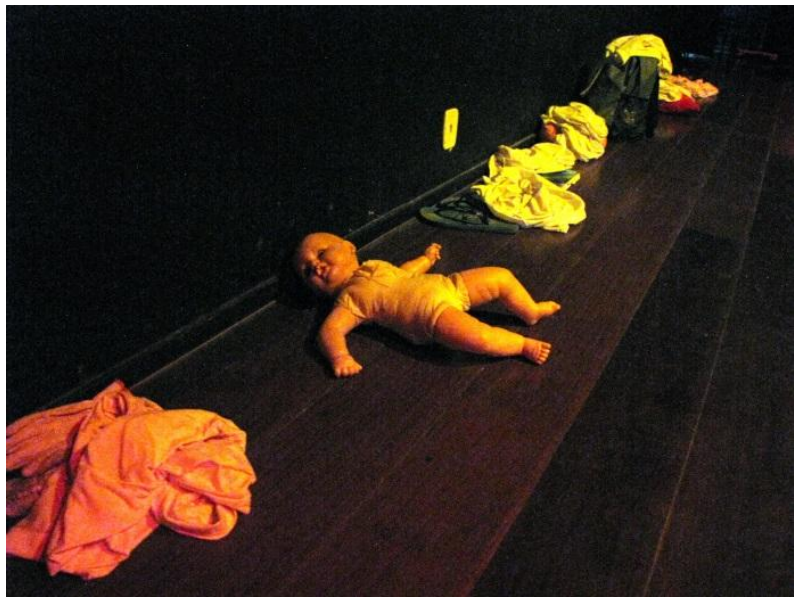

Foto 07

Fotografias de Hugo de Freitas - Arquivo da Autora

Outro ponto que os indignava, de um modo geral, era o descaso diante de situações como a falta de atendimento apropriado e de qualidade nos hospitais públicos; o desemprego desenfreado; comentários racistas na fila de ônibus e/ou no salão de beleza; greves escolares e do transporte público; etc. As referidas situações tornavam-se ainda mais absurdas por haver grupos de pessoas que defendiam esse tipo de conduta/discurso/posicionamento e como uma das participantes dizia em sua proposta de cena: “Atitude Totalmente Incompreensível!” (Fotos 08 e 09).

Figura 3 - Cena Respiro - Totalmente Incompreensível!

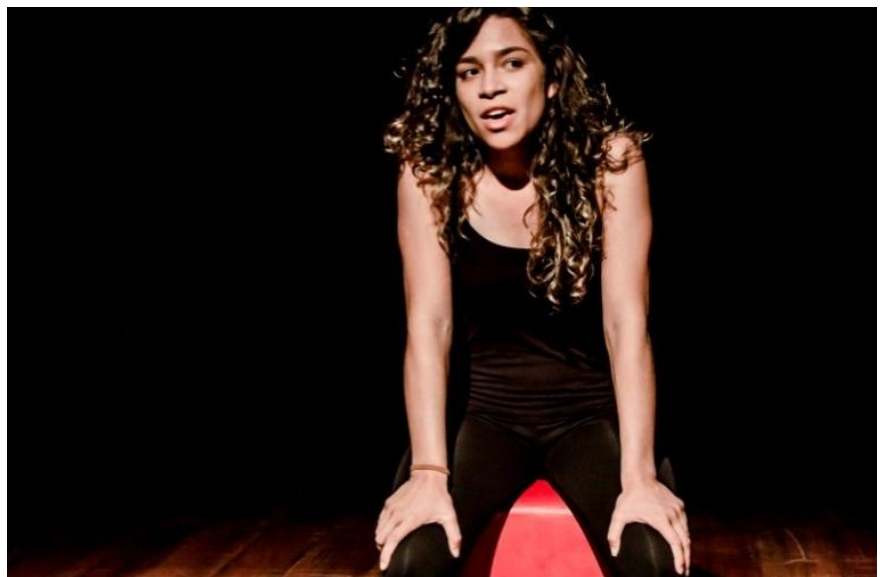

Foto 08

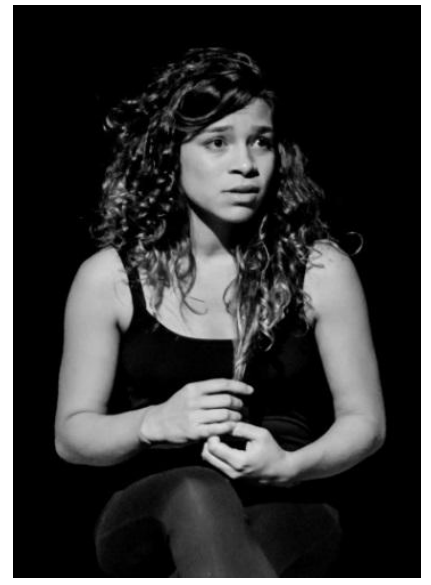

Foto 09

Fotografias de Sartory - Arquivo da Autora 
Segundo depoimento da personagem em cena:

Todas as vezes que eu vejo um mendigo na rua, Me pergunto: por quê ele tá ali?

O que tá fazendo ali?

- Vai trabalhar vagabundo?!

- Vai procurar o que fazer?!

Não entendo por quê

não limpam eles da rua.

Só fede, só enfeia o lugar.

ATITUDE INCOMPREENSÍVEL!

(Trecho da peça: Transições de Impacto).
Semana passada fui arrumar meu cabelo num salão super chique. Quando entra uma menina de cabelo ruim. Opa... Do cabelo cacheadinho...

E fala pra cabeleireira que quer fazer um corte que realce seus cachos.

- O quê? Realçar?

Vai alisar isso menina?!

Não tá vendo que tá feia?

ATITUDE INCOMPREENSÍVEL!

(Trecho da peça: Transições de Impacto).

$3^{\circ}$ Encontro - 27 de agosto de 2015.

1 - Improvisação: "Se eu pudesse mudar alguma coisa, o que eu mudaria?"

Descrição - Criação de cenas individuais a partir do tema.

Objetivo - Como continuidade ao objetivo da oficina de trazer seus questionamentos, o que lhes causava indignação e a possibilidade, por meio do teatro, de discuti-las. Portanto, foi pedido que eles criassem improvisações a partir do tema sugerido.

Resultados - Uma das improvisações retratou a gravidez na adolescência, logo, sem planejamento, o que resultou em uma mãe frustrada (foto 10). A culpa recaiu sobre a filha, que a questionava pela falta de amor, atenção e cumplicidade, uma vez que se encontrava no período da mocidade. A discussão entre mãe e filha limitou-se a acusações, por parte da matriarca, de ter "perdido a juventude", de ter sido abandonada pelo pai e obrigada a carregar o fardo sozinha - criar a filha. Essa, por sua vez, reclamava uma relação saudável entre mãe e filha (foto 11).

Figura 4 - Improvisação a partir do tema: Se eu pudesse mudar alguma coisa, o que eu mudaria?

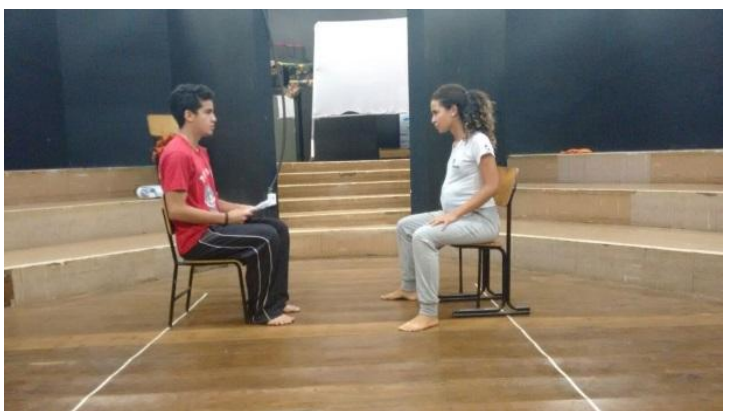

Foto 10

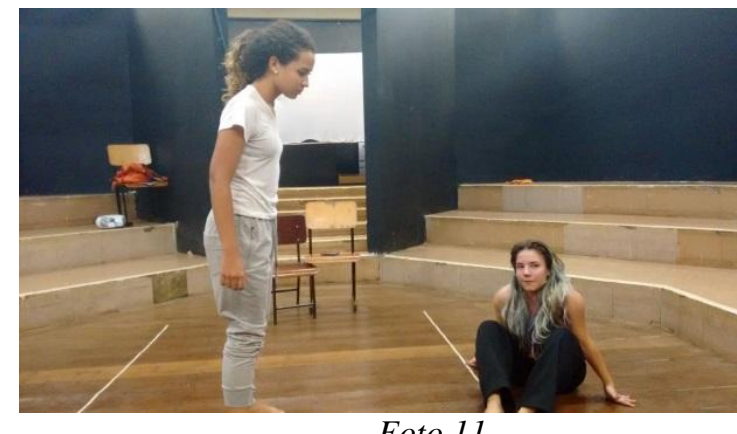

Foto 11

Fotografias de Silvia Paes - Arquivo da Autora 
Essa improvisação foi o ponto de partida para a criação do nosso roteiro final. No espetáculo, a cena foi quadriplicada com o propósito de ressaltar esteticamente o tema abordado, além de mostrá-lo sobre o viés de mãe e filha; pai e filha; mãe e filho; pai e filho (fotos 12, 13, 14 e 15).

Figura 4-Cena: Mãe e filha (quadriplicada).

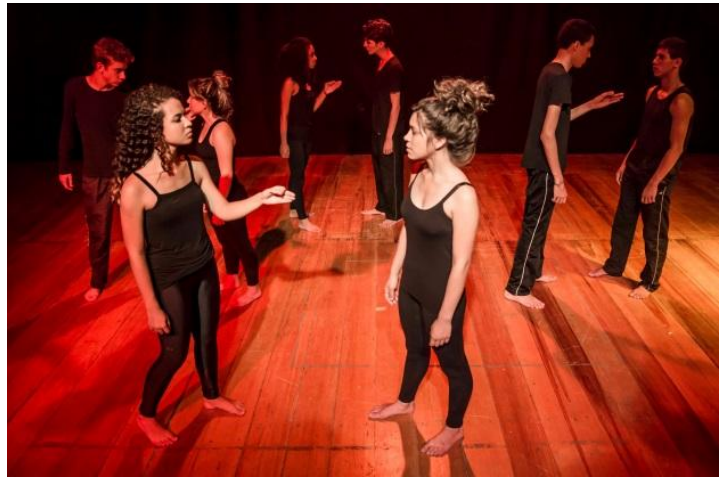

Foto 12

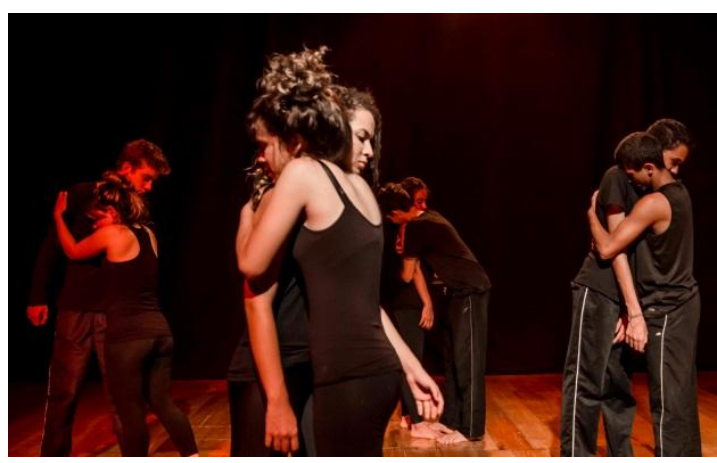

Foto 14

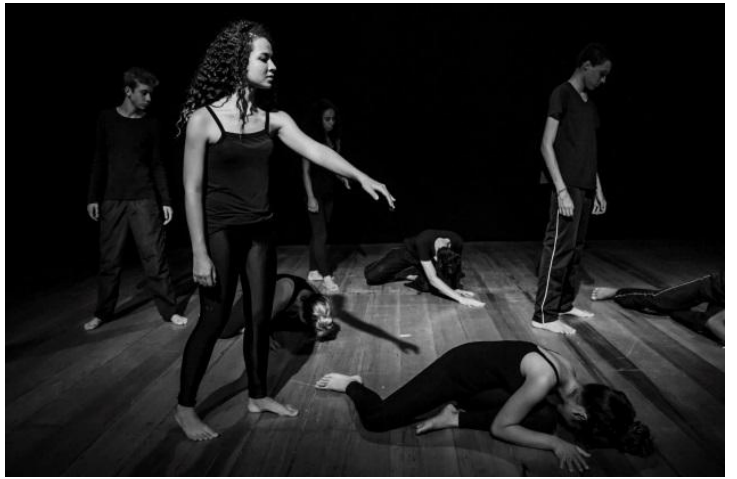

Foto 13

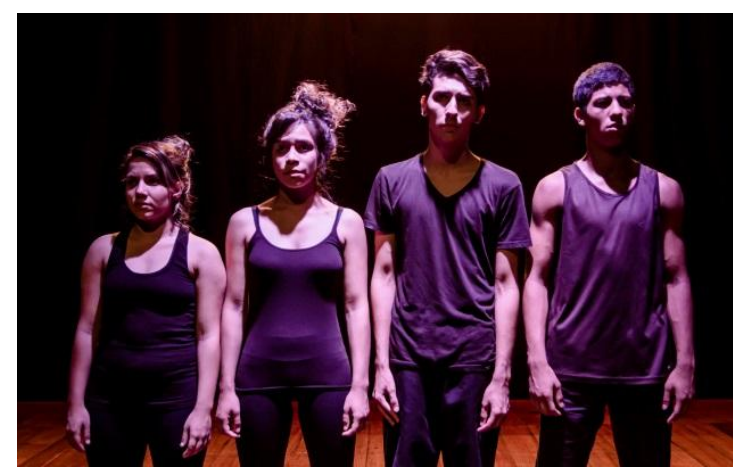

Foto 15

Fotografias de Sartory - Arquivo da Autora

Trecho da peça: Transições de Impacto:

Em muitas casas existem filhos que não se sentem amados por suas mães.

Existem filhos que tem muito, mas ao mesmo tempo, não possuem nada.

Existem mães que não entendem seus filhos.

E filhos que não entendem suas mães.

ATITUTE TOTALMENTE INCOMPREENSÍVEL!

A próxima cena retratou a violência em casa entre pai e filho. $\mathrm{Na}$ (foto 16), o rapaz de boina interpreta o narrador, anuncia e comenta sobre a cena na medida em que o diálogo entre os três personagens se intensifica. A discussão gira em torno de o pai reclamar que a mãe, além de trabalhar fora, vai ao bar com amigos, enquanto ele fica 
em casa com o filho adolescente que, segundo o pai, por ser incompetente, não tem amigos e nem namorada.

A mãe argumenta que tem os mesmos direitos que ele - se trabalha, também tem o direito de se divertir com os amigos. Argumenta ainda que há muito tempo não sai com o marido, que não há diversão entre eles, pelo contrário, basta ela chegar em casa, que ele se acha no direito de sair sozinho com a justificativa de que precisa espairecer. Ela é obrigada a aceitar, ao contrário dele, que não tem limites em fazer o que quer e quando quer.

Diante do argumento da esposa, o marido refuta (foto 17), age com grosseria e a agride psicológica e fisicamente. Ao ouvir os gritos da mãe, o filho adolescente reage, enfrenta o pai, mas também sofre agressão; por sua vez, o pai os chama de fracos e os ameaça ao dizer que, da próxima vez que quiserem se impor, poderão perder a vida. $\mathrm{O}$ narrador finaliza a cena comentando que a violência é assegurada pelos mais fortes e que ela é um retrato do que acontece em muitos lares, incluindo o dele.

Figura 5 - Improvisação a partir do tema: Se eu pudesse mudar alguma coisa, o que eu mudaria?

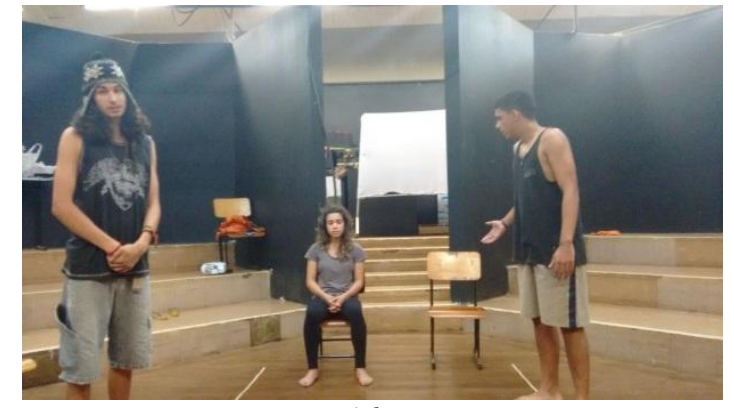

Foto 16

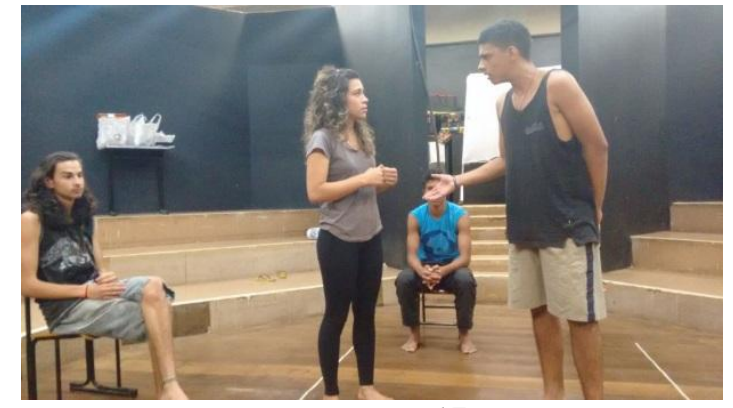

Foto 17

Fotografias de Silvia Paes - Arquivo da Autora

Essa cena também foi inserida em nosso espetáculo. A partir dela, o grupo assumiu discutir a violência familiar sobre outro ponto de vista: do filho incompreensível e violento. Infelizmente não é tão raro, nas famílias brasileiras, pai que agride mãe e filhos. Todavia, diante da iniciativa deles em abordar a violência doméstica, propus que, em vez do pai ser o agressor, que o filho assumisse esse papel; na perspectiva de tratar a mãe como uma escrava em prol de suas demandas (fotos $18 e$ 19). Assim, abordamos o trato nas relações de poder sobre dois vieses: de pais para filhos e de filhos para pais; afinal, esse tipo de abuso não costuma ser unilateral. 
Figura 6 - Cena Surra na Alma - Transições de Impacto.

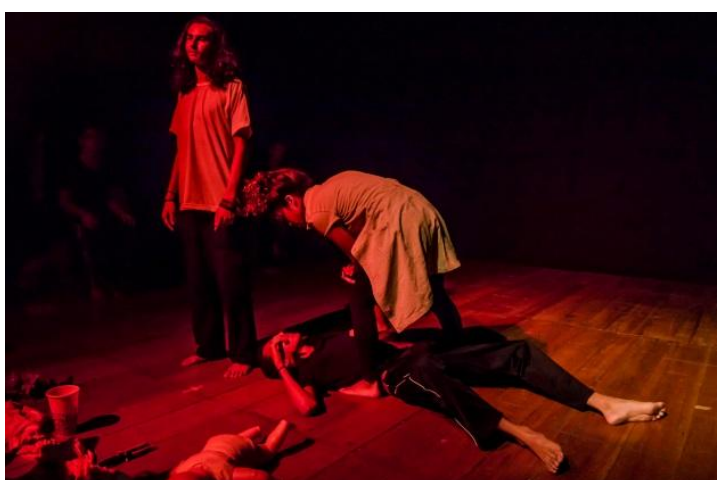

Foto 18

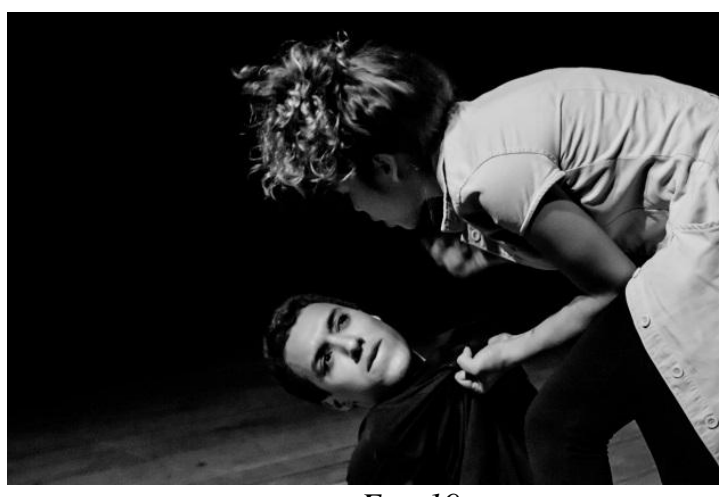

Foto19

Fotografias de Sartory - Arquivo da Autora

As improvisações salientaram situações de opressão de cunho psicológico, nas quais se adequa outra técnica do arsenal do Teatro do Oprimido intitulada de Arco-Íris do Desejo. Embora não vá utilizá-la neste processo diretamente, ela está intrínseca nos conflitos encenados pelos participantes.

O Arco-Íris do Desejo tem como objetivo encenar opressões introspectivas que impedem que o sujeito resolva situações que repercutem em seu convívio social. As apresentações são parecidas com o Teatro-Fórum, porém elas são apresentadas por um grupo específico, no qual as resoluções são discutidas por meio de técnicas terapêuticas.

O tempo em que residiu na Europa, Boal percebeu que as opressões manifestadas nos grupos em que aplicava o Teatro do Oprimido eram diferentes das de cunho social e econômico presentes nos países da América Latina. Os europeus manifestavam opressões internas, de cunho emocional e pessoal. O Arco-Íris do Desejo - também conhecido como Método Boal de Teatro e Terapia - surge dessa aliança com o propósito de combater os opressores internalizados na mente dos participantes, que Boal irá classificar como os tiras que residem dentro de nossas cabeças.

Essa técnica foi criada por Boal em parceria com sua esposa - Cecilia Thumim Boal - que, além de atriz, é psicanalista. A forma que eles encontraram de combater esse tipo de opressão, foi proporcionar o confronto entre o oprimido e os "policiais imaginários", concretizando-os em imagens para, assim, conseguir minimizar as opressões subjetivas. 
Até então, Boal havia trabalhado com opressores reais, como patrão, latifundiário, policiais, entre outros. Já, na Europa, as opressões eram subjetivas, embora tivessem suas origens na objetividade, ou seja, com personagens reais, mas que mantinham as opressões internalizadas nesses sujeitos, impedindo-os de agir. Como o autor observa em sua experiência em Arco Íris do Desejo (2002, p. 54).

É preciso que todos os elementos singulares do relato individual adquiram um caráter simbólico e percam as restrições de sua singularidade, de sua unicidade; assim, através da generalização, e não por meio da singularização, abandonamos um terreno mais propício a ser estudado por psicoterapeutas e nos limitamos a nos ocupar daquilo que é nossa área e nosso privilégio: a arte teatral.

Por ser uma técnica que vivencia práticas terapêuticas, já foi em muitos momentos comparada ao Psicodrama, termo criado pelo psiquiatra Jacob Levy Moreno presente em sua obra: Teatro da Espontaneidade e Psicodrama (1984). Porém, o que Boal propõe é conscientizar o sujeito em prol de trabalhar o coletivo. Como analisa Sanctum:

Quando Boal sugere práticas que investigam a opressão subjetiva sofrida por determinado sujeito ou grupo, é preciso atentar um ponto fundamental de sua metodologia: o Teatro do Oprimido tem por finalidade a reflexão das ações individuais para a transformação de atitudes opressivas da sociedade. Isto é, observando o indivíduo e refletindo sobre as opressões que sofre particularmente, encontramos estratégias de combate à opressão sofrida individualmente por um grande número de pessoas (2011, p. 36):

Mesmo que na construção de cenas para o Teatro-Fórum o tema tenha sido proposto por um participante, transfere-se a problemática levantada para o coletivo, de modo que o grupo teatralize os conflitos e dialogue com a plateia em busca de soluções. Já no Psicodrama, o tema é sugerido por um participante e os procedimentos terapêuticos são apresentados individualmente, mesmo que o problema possa ser comum aos demais participantes. Como Boal salienta em STOP: C'est Magique! (1980, p. 131). 


\begin{abstract}
A meu ver, essa é a primeira diferença entre um e outro: o teatro-foro tende a ocupar-se da primeira pessoa do plural (mesmo que o tema seja proposto por um só indivíduo), enquanto o psicodrama tende a ocupar-se de um indivíduo, da primeira pessoa do singular, mesmo que o problema possa revelar-se coletivo.
\end{abstract}

Por mais que o teatro aborde vivências de cunho terapêutico, ele não é terapia; por concentrar seu trabalho no coletivo. Já Moreno se utiliza do teatro para combater distúrbios psíquicos, do que ele vai denominar Teatro Espontâneo - uma técnica que utiliza a dramatização como instrumento terapêutico. Moreno, como Boal, defende que não pode haver ruptura na relação estabelecida entre espectador e espetáculo para que a experiência estética se processe de forma plena. E essa relação ocorre quando o que é apresentado causa ativação no espectador. Como reflete Moreno:

A força liberada pelo teatro e pelo drama não está no palco, no ator, não está atrás do cenário, nem no produtor, nem no dramaturgo; está na plateia perante o proscênio. $\mathrm{O}$ espectador transforma-se em ator na medida em que se descobre em conflito com as pessoas que atuam no palco. [...] A divisão da comunidade em duas partes, atores e audiência, também divide em duas partes a ilusão e o prazer estético, partes estas que só possuem significado em sua unificação (1984, p. 46).

O roteiro começava a ser desenhado. Nessa cena, em específico, foi anunciado outro tipo de personagem, o responsável por costurar a dramaturgia do espetáculo: o narrador. Mais tarde o define como Coringa - aquele que comenta a cena e, de certa forma, contextualiza o espetáculo em sua totalidade.

\title{
$4^{o}$ Encontro - 03 de setembro de 2015.
}

\section{1 - Criação do nome do grupo}

Descrição - Criamos o nome do grupo - Oprieram -, a partir do entendimento em torno da conjugação do verbo oprimir. Como o personagem Coringa relata durante a peça, oprimir significa dominar ou reprimir com violência; abuso de poder; ter sob jugo; causar aflição ou angústia; exercer pressão forte sobre; pressionar. 
Objetivo - Esse verbo resumiu as questões levantadas pelo grupo quando, durante os encontros, os indagava o que mais os indignava e/ou se eles pudessem mudar algo que os incomodava, o que eles mudariam? As questões levantadas relacionavam-se às opressões sofridas por eles no período da infância e também por crianças próximas, quando se sentiam indefesas perante o abuso de poder exercido por seus responsáveis.

Resultados - Após definirmos o nome, criamos um grito de guerra: Opressão não, Oprieram! Que era dito sempre ao final de cada encontro depois que todos resumiam, em uma palavra, o que tinha sido a oficina para cada um. Esse foi o nosso ritual ${ }^{3}$, que nos fortaleceu enquanto grupo, enquanto tantas intimidades postas a serviço da teatralidade. Descobrimo-nos durante o processo, nos permitimos, transformamos nossas histórias e criamos outras a partir de nossas vivências e de como enxergamos as relações sociais à nossa volta.

\section{2 - Floresta de Sons - $3^{\text {a }}$ Categoria -ativando os vários sentidos}

Descrição - O grupo se dividiu em duplas, onde um exerceu o papel de cego e o outro de guia. Este emitiu um som no ouvido do parceiro que experenciou ser o cego, de modo que ele se locomovia no espaço na tentativa de seguir o som e ficar próximo do seu guia. Como existiam vários guias, o ambiente em que foi feito o jogo tornou-se bastante sonoro, de modo que cada cego precisava distinguir o som do seu guia em relação aos demais. Depois de um tempo no jogo, as duplas mudavam de função: quem era cego se tornava guia, e o guia se tornava cego.

Objetivo - A atividade ser realizada com olhos fechados aguça três dos cinco sentidos: olfato, tato e audição; em especial esse último, por propiciar uma seleção auditiva referente ao parceiro que divide a dinâmica do jogo.

Resultados - Em jogos, como esse, em que as duplas permitem a vivência de diferentes papéis, a regra estabelecida em cada exercício ressalta a importância de que cada participante vivencie os dois lados, ou seja, as duas funções propostas. Nesse jogo em específico, ele poderá experimentar as sensações causadas por estar de olhos fechados, sendo guiado por um som no meio de tantos e, na outra função, experenciar a responsabilidade de cuidar do parceiro e de observar como ele se porta diante dos obstáculos que surgem por estar sem a visão.

3 O termo ritual nesta pesquisa se refere a uma prática que o grupo consagrou. 
Geralmente, os jogos teatrais propostos pelo Teatro do Oprimido permitem a atuação em dois prismas - do líder e do liderado -, o que amplia as diferentes facetas dessas funções e de como cada um assume possibilidades diferenciadas de resolver uma problemática advinda de um jogo e/ou de uma cena.

$5^{\circ}$ Encontro - 10 de setembro de 2015.

1 - Término do relato: "O que mais me indigna?"

Descrição - Cada participante apresentou uma cena individual respondendo artisticamente o tema proposto.

Objetivo - Como o Teatro do Oprimido procura investigar as indagações e indignações dos participantes, propus-lhes que trouxessem, através da linguagem teatral, questões pessoais sobre determinados temas que os provocariam a se colocarem diante de situações de opressão.

Resultados - Ao refletirmos sobre as improvisações apresentadas, começamos a visualizar o quê queríamos falar mediante essa experiência. Percebemos que as cenas se respaldavam na discussão acerca das consequências que uma infância mal sucedida refletiria na índole, escolhas e expectativas de um adolescente.

Outro tema que eles quiseram abordar se tratava do abuso psicológico e físico que pessoas da própria família exerciam quando eram crianças. Entre eles não houve abuso sexual propriamente dito, mas houve intromissões por parte de membros da família nas quais a palavra não imperava: "Não dará grande coisa no futuro; não será um doutor; não dará conta de ser mãe e ter uma vida independente; esse aí já nasceu um perdedor; etc." A partir da problemática levantada, criamos as seguintes cenas que foram incluídas em nosso roteiro final: 
Figura 7 - Cenas sobre abusos físicos e psicológicos.

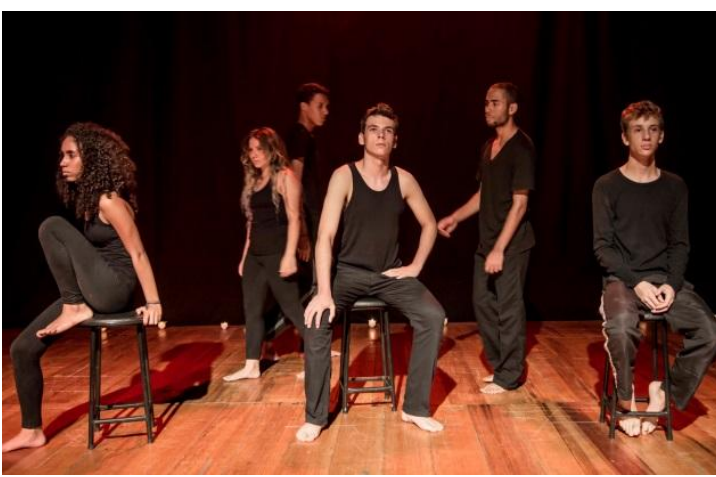

Foto 20

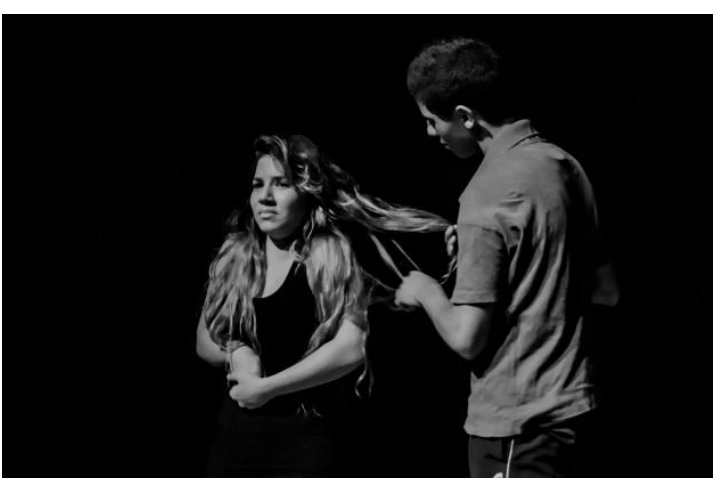

Foto 22

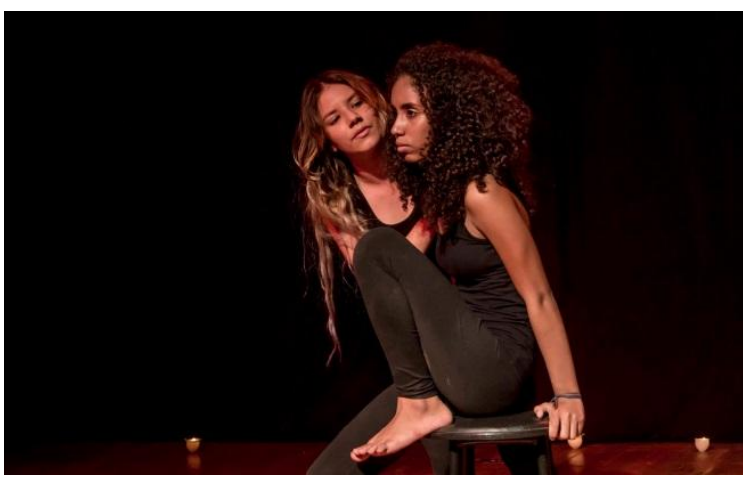

Foto 21

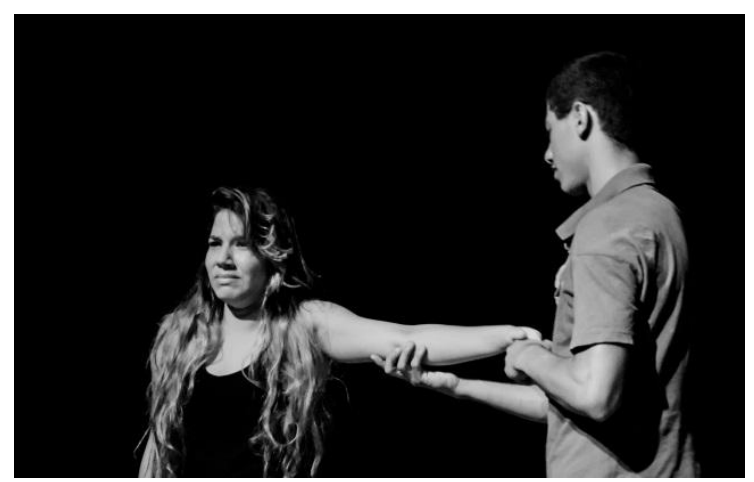

Foto 23

Fotos de Sartory - Arquivo da Autora

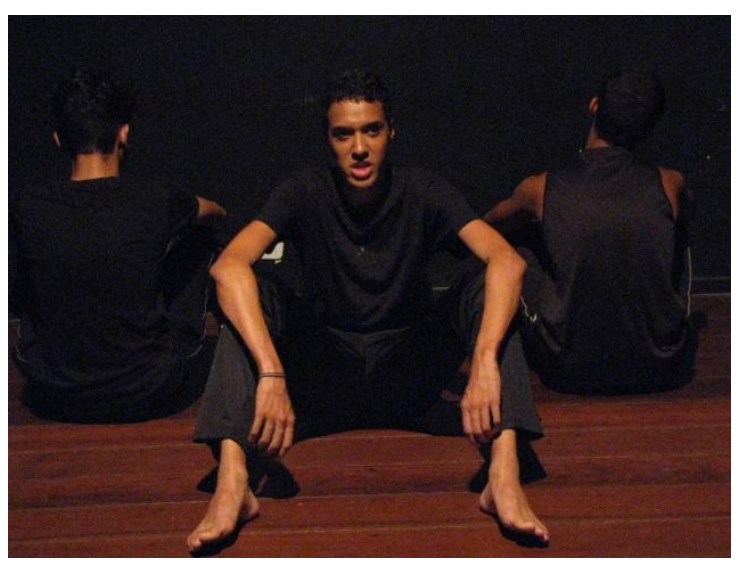

Foto 24

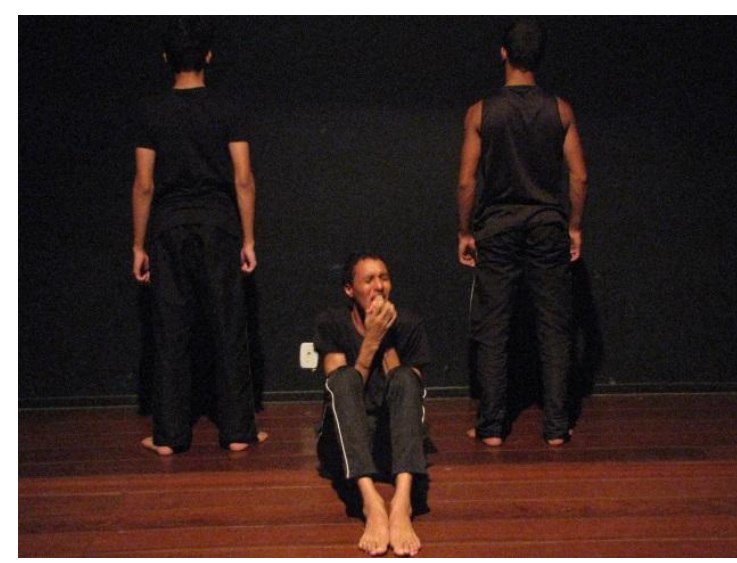

Foto 25

Fotos de Hugo de Freitas - Arquivo da Autora

Doamos história, alma, sentimento, corpo, cabeça e tudo que podíamos. Nunca me achei capaz de fazer cenas extremamente dramáticas e quando me percebi no meio de uma cena de estupro, compreendi que não se faz, e sim, se coloca no lugar do outro. Sente o outro. Entende o outro. Apenas o outro. Sem querer fazer cena (D. A., 17 anos). 
O relato dessa adolescente demonstra que essa oficina ofereceu a ela e, também aos outros integrantes, um espaço no qual poderiam experimentar situações e interpretações de personagens que os colocavam frente aos pré conceitos oriundos dos temas levantados. Puderam vivenciar estar ora como opressores, ora como oprimidos permitindo, portanto, a abrangência desses dois posicionamentos, logo, a abertura de discutir as relações de poder impostas.

\section{2 - Floresta de Sons com variante (Julián)}

Descrição - Consiste em dispor os participantes em ambas as funções ao mesmo tempo. Em círculo, eles são numerados em 1, 2, 1, 2, 1, 2, e assim por diante até numerar todos da roda. Os que são o número 1 se colocam à frente do colega de número 2 que estão a sua direita e produz um som diferente do utilizado no exercício anterior. Depois cada um volta para a posição inicial na grande roda. Agora os que são número 2 vão para frente dos colegas que estão a sua direita de número 1 e produzem outro som diferente do que receberam. Cada participante ouviu um som de um colega e emitiu o som para outro, todos são ao mesmo tempo cegos e guias.

Objetivo - Além da percepção sonora, cada participante tinha que saber quem estava a sua direita e a sua esquerda através do tato, perceber a temperatura e textura das mãos de quem estava ao seu lado e conseguir identificá-lo sem o auxílio da visão. Depois, todos andaram pela sala de olhos fechados e, quando eu dei o sinal para começarem, cada um emitiu seu som ao mesmo tempo em que saiu a procura do som que ouviu. Quando o encontrou, deu as mãos ao seu guia e só parou de emitir o som quando foi encontrado pelo outro participante. No final do jogo, os participantes só podem abrir os olhos quando estivessem de mãos dadas com seus respectivos: cego e guia.

Resultados - Ao propiciar um exercício de olhos fechados, trabalha-se a confiança em si e no grupo. Sentimento este que transcende quando se está em cena, pois o ator estabelece um jogo com os elementos que compõem a linguagem da encenação e com o público e, para isso, é preciso estar inteiro em cena, ou seja com seus cinco sentidos a postos na arte de interpretar, na arte de dizer algo através do jogo cênico. 


\section{3 - Quantos "as" existem em um "a"? - da 2a Categoria}

Descrição - Em círculo, cada participante dava um passo para frente e dizia a letra $a$ de diversas maneiras utilizando sensações, sentimentos, para se expressar. Depois cada um dizia sim, querendo dizer sim; sim, querendo dizer não; não, querendo dizer não e não, querendo dizer sim. Para finalizar, eu pedi que um deles se manifestasse dizendo uma frase que todos pudessem decorá-la. O próximo passo foi cada um dizê-la explorando tipos de intenções, sentimentos que já a diferenciava.

Objetivo - Trabalha-se a intenção de texto, entonação, subtexto, dicção que são necessários para o trabalho do ator. Mesmo que a intenção do Teatro do Oprimido não seja a formação de atores, os participantes são inseridos nesse contexto ao utilizarem técnicas de atuação, uma vez que as situações de opressão são discutidas pelo viés da teatralidade.

Resultados - Assim como no ofício do ator, uma letra, palavra ou frase ganham diferentes significados, dependendo do modo como são ditas e interpretadas.

\section{4 - O Círculo de Nós - $1^{\text {a }}$ Categoria - sentir tudo que se toca}

Descrição - Nesse jogo, os participantes se encontravam no centro da roda como se fossem um bloco, todos bem juntinhos com os braços para cima. Eles deram-se as mãos: com a direita pegavam a mão de um colega, com a esquerda a de outro; quando todos estavam de mãos dadas, eu dei o comando de se afastarem sem soltar as mãos e nem mudá-las de posição. Um grande nó foi criado e o desafio era tentar desfazê-lo e voltar para a posição inicial.

Objetivo - Nesse exercício, o recurso da voz não é aplicado. Suscitando, assim, que os participantes utilizem da expressão facial e corporal para se comunicarem, e as expressões ficam mais claras por não ter a voz como subterfúgio.

Resultados - Desfazer o nó é uma tarefa conjunta onde cada um exerce um papel importante em prol do sucesso coletivo. No decorrer do exercício, alguns líderes vão surgindo, até inconscientemente, devido a necessidade do jogo de se fazer ouvir através do corpo e de se movimentar em conjunto com o intuito de desatar o nó.

Quantos nós criamos, quantos nós são inseridos e nem todos conseguimos desatar; talvez precisamos ouvir e/ou nos façamos ouvir para que alguns nós se 
dissolvam, alguns problemas se resolvam. Nesse grupo, o nó permaneceu, o grupo tentou de várias maneiras desatá-lo, mas como não podia soltar as mãos e nem mudar sua direção, o grupo finalizou o exercício com alguns nós na estrutura criada.

$6^{\circ}$ Encontro - 17 de setembro de 2015.

\section{1 - Um, dois, três de Bradford - $2^{\mathrm{a}}$ Categoria}

Descrição - Formaram-se duplas, um de frente do outro para contar de 1 a 5 alternadamente por duas vezes. Ou seja, se pensar que as duplas são A e B, na primeira vez o A será 1, 3 e 5, o B 2 e 4; na sequência, a segunda vez, o A falará os números 2 e 4 e o B 1, 3 e 5 . Aos poucos, cada número foi sendo substituído por um movimento seguido de som, e tanto o A como o B criaram e imitaram o som e movimento proposto pela dupla. No final do jogo, os números não eram mais ditos e, sim, representados pelas expressões corporais dos participantes.

Objetivo - A sequência de movimentos propõe foco, atenção, ativa a memória e trabalha possibilidades de expressão corporal.

Resultados - Ao diferenciar um movimento do outro, o jogo adquire a dinâmica necessária para trabalhar pontos essenciais na prática teatral.

\section{2 - Fotografar a Imagem $-4^{\text {a }}$ Categoria}

Descrição - O jogo resumiu-se em dividir o grupo em A e B, eles ficaram um de frente para o outro e cada componente do A formava dupla com um do B mantendo uma certa distância entre eles. O grupo A virava de costas com os olhos fechados e o grupo B fazia uma imagem individual, ao meu comando. O A virava, abria os olhos e rapidamente os fechava e, ainda de olhos fechados, tentava reproduzir a imagem que viu de sua dupla. Cada componente do B se dirigia a sua dupla e modelava detalhes da imagem, incluindo a expressão facial, para que ficasse igual ao que ele propunha. Depois trocava, era a vez do grupo B virar e fechar os olhos para que o A pudesse fazer sua imagem e depois do comando, o A realiza o mesmo procedimento que o B.

A segunda etapa do exercício era realizar a imagem em conjunto, como se fosse uma foto coletiva em que cada componente observaria a sua dupla para que pudesse 
reproduzir a imagem mais próxima da criação do colega. O comando era o mesmo, primeiro o grupo A e em seguida o grupo B.

Objetivo - Trabalhar em equipe com o intuito de vivenciar, em primeira instância, a expressão individual e, no segundo momento, a expressividade corporal no coletivo, com ênfase no trabalho em grupo.

Resultados - As imagens são feitas de olhos fechados e sem o recurso da voz. O desafio de fazê-las no coletivo requer atenção tanto em sua reprodução, quanto de quem estiver do seu lado, pois este tem que corresponder a dupla formada do outro grupo.

\section{3 - Improvisação - “O meu sonho é...?”}

Descrição - Dividi-os em 3 grupos e pedi que improvisassem uma cena com o tema proposto.

Objetivo - Debater sobre seus desejos, metas e conhecê-los mais em relação às suas perspectivas futuras.

Resultados - Algumas cenas desta apresentação foram aproveitadas em nosso espetáculo, pela forma em que eles se posicionaram diante do abandono e da violência doméstica, como exemplificam essas duas fotos (26 e 27).

Figura 8-Cena Abandono.

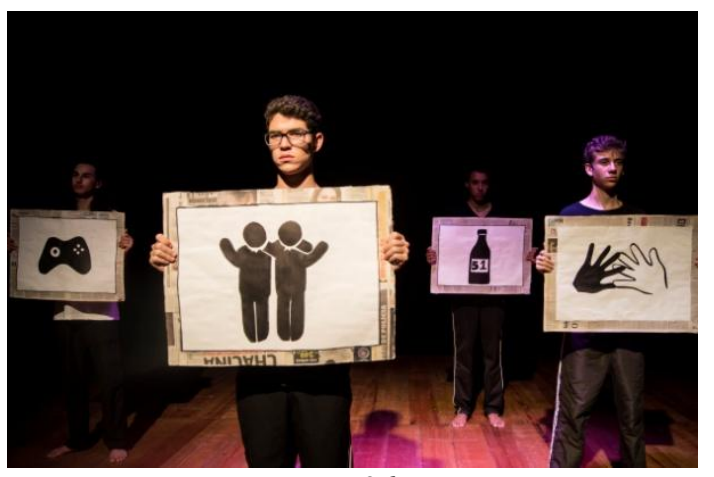

Foto 26

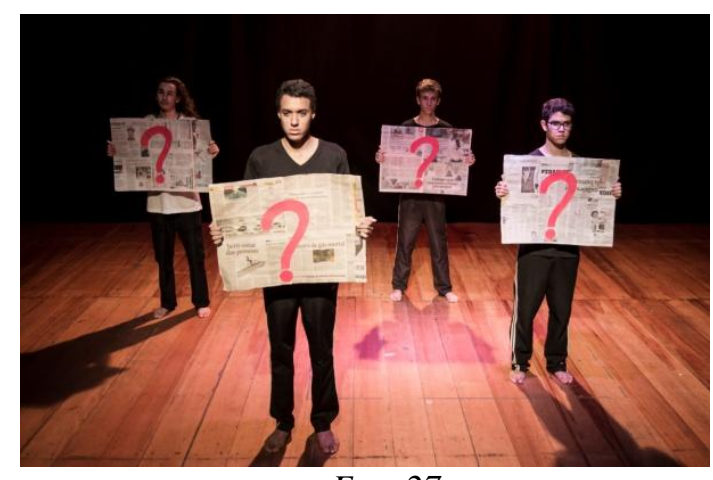

Foto 27

Fotos de Sartory - Arquivo da Autora

Cartaz 1 - Eu abandonei o meu pai quando ele quis me dar um abraço e eu recusei.

Cartaz 2 - Eu abandonei minha vó quando ela me chamou de mal educado e eu dei um tapa na cara dela.

Cartaz 3 - Eu abandonei meu irmão quando deixei de dar um abraço nele pra ficar jogando vídeo game.

Cartaz 4 - Eu abandonei minha mãe quando ela queria falar comigo e eu saí pra beber com meus amigos. 
Essa cena referiu-se ao abandono dos adolescentes para com a família, pelo grupo entender que esse fato não ocorre unilateralmente. Escolhemos, em maioria, abordar cenas de opressões sobre o viés dos adolescentes perante a família, amigos, instituições - como a escola em especial. A maioria dos conflitos foram abordados sob esse prisma, porém escolhemos algumas cenas em que as questões levantadas tinham como opressores os próprios adolescentes por evidenciar que eles também se utilizam de abuso de poder diante da perspectiva que se tem o direito de experimentar, ousar, vivenciar coisas sem limites, sem prerrogativas e sem imposições dos seus respectivos responsáveis.

\section{4 - Homenagem a Magritte $-4^{\text {a }}$ Categoria}

Descrição - Como o próprio nome anuncia, esse jogo é uma homenagem ao pintor surrealista belga René Magritte, que foi um dos maiores representantes do realismo mágico -, ou seja, da justaposição de objetos corriqueiros em um contexto fora do usual.

Magritte foi um dos artistas que mais representou esta técnica e em sua obra " $A$ Traição das Imagens", as palavras presentes nos quadros a seguir imperam uma aparente contradição: a imagem de um cachimbo que não satisfaz a necessidade do objeto real (fotos 28 e 29).

Figura 09 - Imagens de René Magritte.

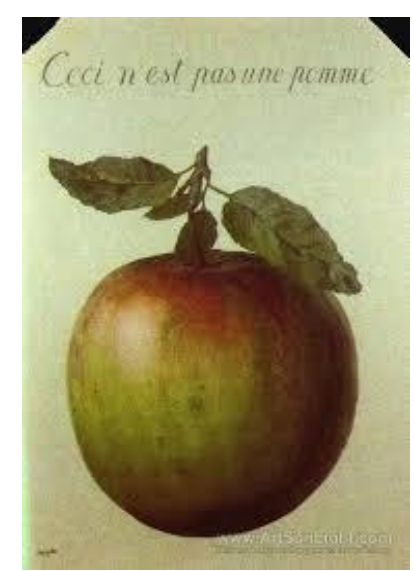

Foto 28

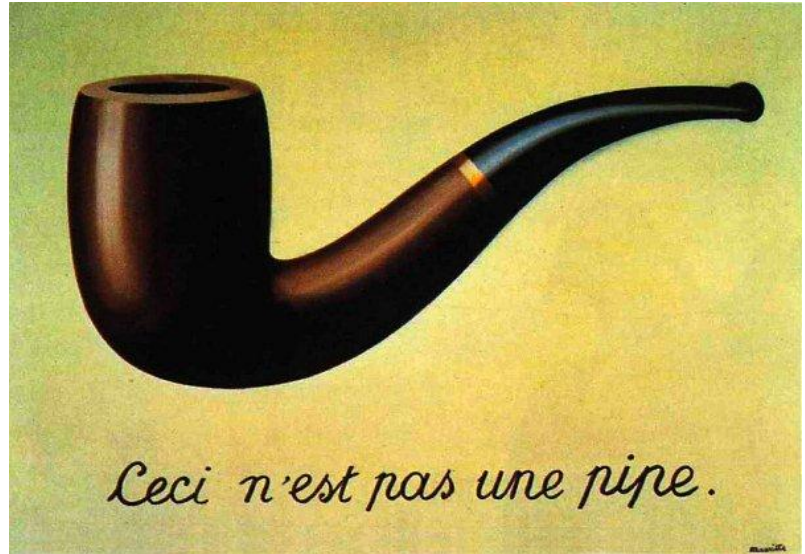

Foto 29

Fonte: http://obviousmag.org/archives/2011/01/rene_magritte.html. Acesso em 30 de março de 2016 
Boal acrescenta:

O que Magritte quis dizer realmente foi que um cachimbo ou uma maçã pintados em um quadro não são nem maçã nem cachimbo, são obras de arte, são pintura, artes plásticas. Esta maçã não é uma maça, e não é mesmo: basta tentar comê-la para se certificar da verdade do título, aparentemente mentiroso (BOAL, 2006, p.216).

Não importa o quão fiel possamos representar uma imagem, é sempre impossível capturar a sua essência. Porém é possível ressignificá-la ao transformá-la em outros objetos, principalmente quando os objetos que se tem para manipular em cena e/ou compuser o cenário não os servem, aparentemente, mas podem ser manipulados de formas diferentes, de modo a se tornarem outros.

Nessa perspectiva, o jogo é realizado com os participantes em roda e o Multiplicador leva uma garrafa vazia até o centro dizendo: "Esta garrafa não é uma garrafa, então o que será?”. Um por um vai até o centro da roda, pega a garrafa e a transforma em diferentes tipos de objetos ao executar uma ação em conjunto com seu corpo e os outros participantes verbalizam o novo significado dado à garrafa. Depois o exercício é feito com uma cadeira e, por último, com uma mesa.

Objetivo - Costumo aplicar esse jogo quando percebo que os participantes entenderam que essa oficina tem como objetivo utilizar a linguagem teatral como ferramenta para discussão e possibilidade de diálogo a situações de opressão.

Resultados - Os objetos transformados, ou seja, sendo utilizados de outras formas, abrem possibilidades de reinvenção e de utilização ao compor o cenário no espaço cênico.

$7^{\circ}$ Encontro - 24 de setembro de 2015.

\section{1 - Hipnotismo Colombiano - $1^{\text {a }}$ Categoria.}

Descrição - Formaram-se duplas, sendo que um seria o hipnotizador e o outro o hipnotizado. O hipnotizador punha a mão direita próxima ao rosto do hipnotizado, de modo que a palma de sua mão ficava rente ao queixo do colega. Este se guiava pela mão do hipnotizador que a movimentava de diferentes maneiras: para cima, para baixo, para trás, para frente, retos e circulares fazendo o hipnotizado trabalhar o equilíbrio e 
explorar movimentos variados, se possível, àquelas que proporcionavam ativar estruturas musculares pouco utilizadas.

Depois de um tempo, trocavam-se as funções. Ao experimentarem serem hipnotizadores e hipnotizados, cada dupla guiava e era guiada simultaneamente, ou seja, cada participante era guiado pela mão direita do colega, sem esquecer-se de guiar também.

Objetivo - Quanto mais se explora movimentos extracotidianos, melhor se prepara o corpo para construção de repertórios em prol de personagens, assim como, a consciência de seus limites e do que pode ser aperfeiçoado.

Resultados - A prática nos exercícios teatrais prepara o corpo para possibilidades infindas, levando-o a compor personagens em sua totalidade. A palavras, nesse caso, auxilia o discurso imerso na expressividade corporal.

\section{2 - A luta de Galos - $4^{\text {a }}$ Categoria}

Descrição - As duplas ficavam de frente, aparentemente imóveis, e quando era dado o sinal para começarem, uma delas acusava o outro de algo - que podia ser de qualquer fato -, e o colega não podia negar a acusação, pelo contrário, tinha que aceitá-la e tentar se justificar. Depois era a vez de o acusado acusar e o outro também tinha que aceitar, porém com o direito de se defender. A cada justificativa cabiam mais acusações, e as histórias improvisadas iam sendo preenchidas de situações imaginárias que podiam ter lógicas ou não. Era uma verdadeira briga entre galos e/ou galinhas.

Objetivo - Trabalhar a capacidade de improvisar textos, a partir de situações criadas por cada dupla.

Resultados - Esse tipo de jogo prepara-os para as cenas que serão construídas durante o processo. Sua eficácia está em oferecer-lhes base para a criação de argumentos diante das improvisações com a entrada do público na Cena-Fórum.

\section{$8^{\circ}$ Encontro - 01 de outubro de 2015.}

\section{1 - Análise da peça teatral}

Descrição - Leitura Dramática: Murro em Ponta de Faca. 
Objetivo - Primeiro, oferecer-lhes a oportunidade de ter contato com um texto dramático. Segundo, conhecer a dramaturgia de Boal sob o prisma de uma peça autobiográfica, pois, assim como os personagens, ele viveu em exílio durante 15 anos.

Figura 10 - Leitura Dramática: Murro em Ponta de Faca

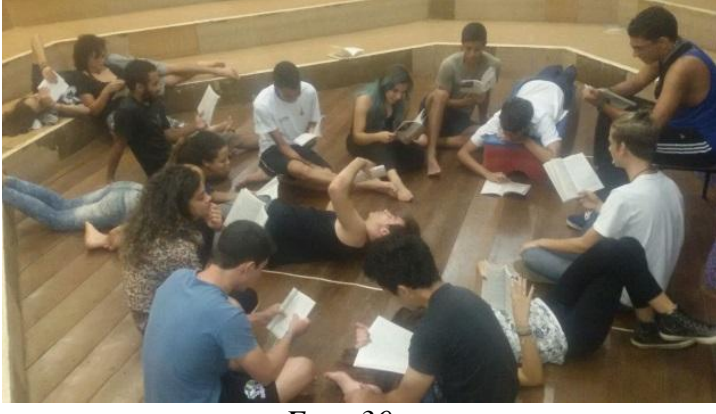

Foto 30

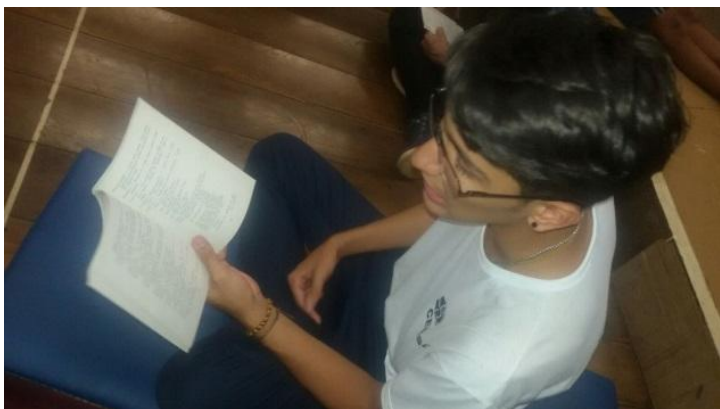

Foto 32

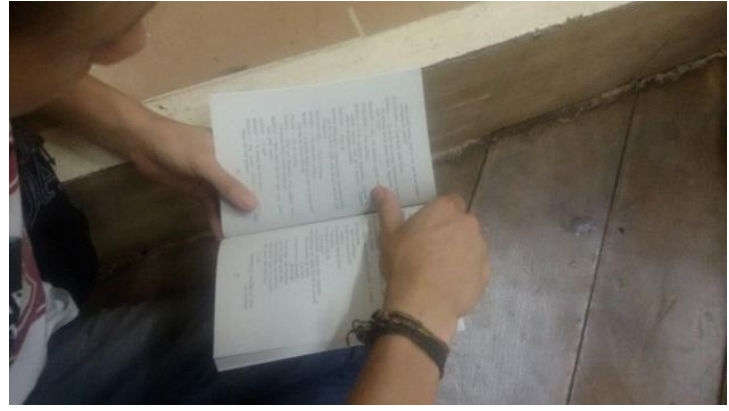

Foto 31

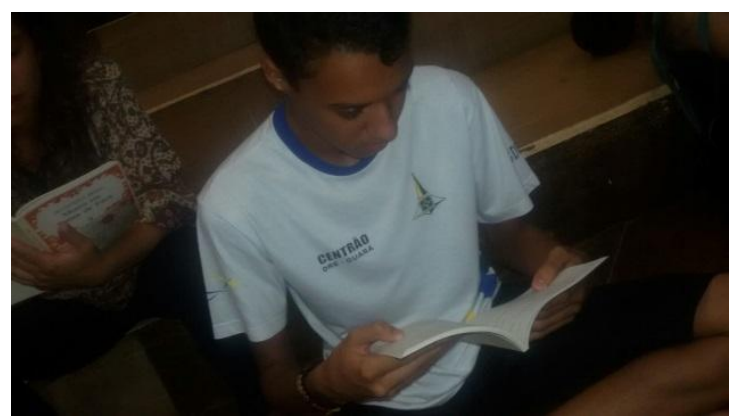

Foto 33

Fotografias de Silvia Paes - Arquivo da Autora

Boal escreveu Murro em Ponta de Faca em 1978, em Portugal. Trata-se de uma peça que narra a história de seis casais exilados - Doutor e Margarida (Marga), Barra e Foguinho, Paulo e Maria. Eles são obrigados a conviver em espaços confinados, de malas sempre prontas. Tudo o que eles tinham e faziam cabia dentro de uma mala a qual estava sempre pronta para deixar lugares e ir atrás de outros em suas rápidas e constantes fugas. Isso é o que observa Desirree dos Reis Santos em sua dissertação Novos Horizontes: As criações teatrais de Augusto Boal nos anos de exílio (2014), ao comparar o exílio dos personagens com o de Boal e de tantos brasileiros que forçosamente tiveram que sair do país:

A sensação de uma interminável viagem marcou a vida de boa parte dos exilados. A incerteza da volta, as dificuldades de adaptação a novas realidades e a luta pela sobrevivência em terras estrangeiras são situações vividas por alguns exilados e foram desenvolvidas por Boal no texto de Murro (SANTOS, 2014, p. 114). 
Ao escrever essa peça, Boal expôs sua condição de exilado. Denunciou, por meio da dramaticidade teatral, as atrocidades que sustentaram a ditadura militar. Essa realidade de exílio, que beirava a punição, revelou um sistema que utilizava do medo, da tortura, das prisões e do ato de expulsar para manter o poder. A árdua tarefa de fazer e desfazer malas, pousos em países que esperançavam acolhidas e os perigos que uma vida errante proporcionava. Esses pontos vão de encontro com os questionamentos dos adolescentes que traziam nas improvisações propostas o exílio de conviver com prerrogativas e dificuldades oriundas da infância.

Resultados - O contexto histórico e cultural presente nas relações entre esses personagens contribuíram para a criação da Puta em nosso espetáculo. Ela se apropriou de um trecho, do segundo ato, da personagem enigmática Maria, pois seus argumentos diante da situação de perseguida política influenciaram nas escolhas de condutas defendidas por nossa personagem. A seguir, segue um trecho da peça:

Figura 11 - Cena: Puta.

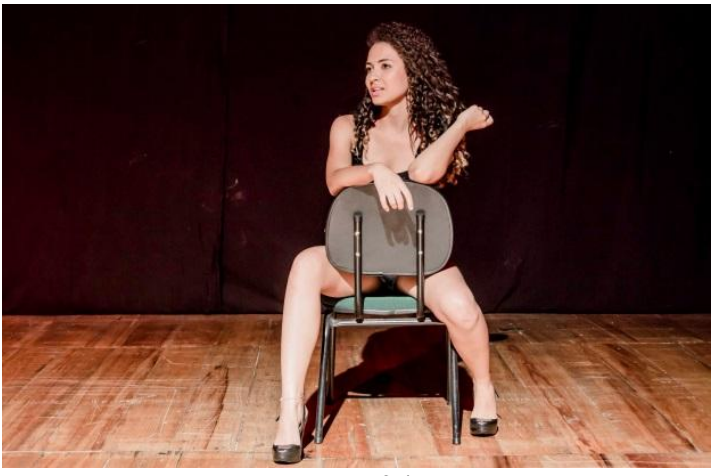

Foto 34

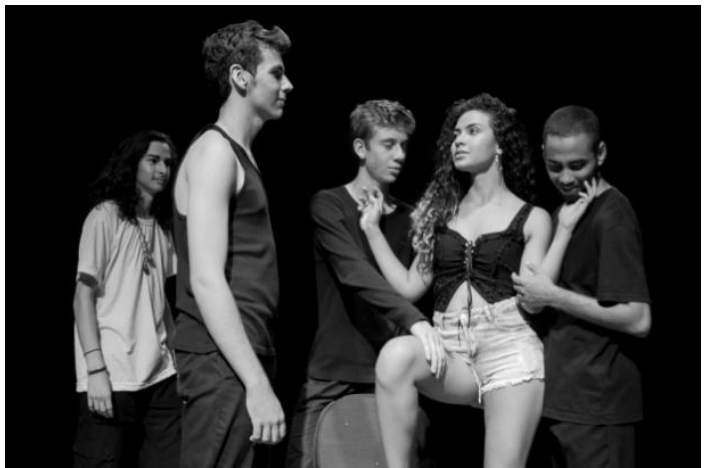

Foto 36

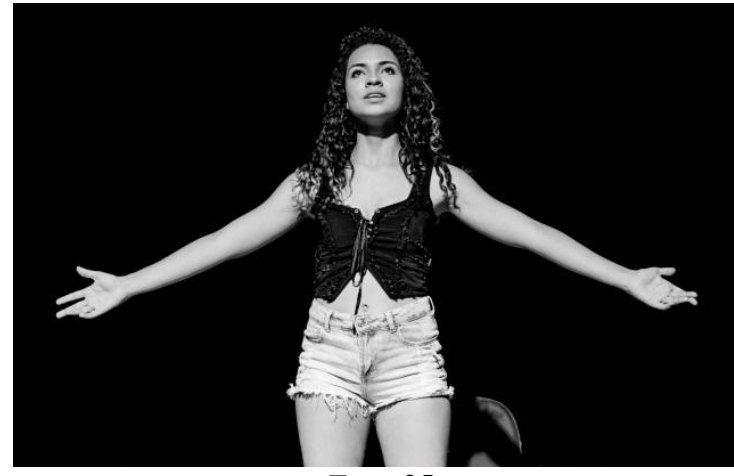

Foto 35

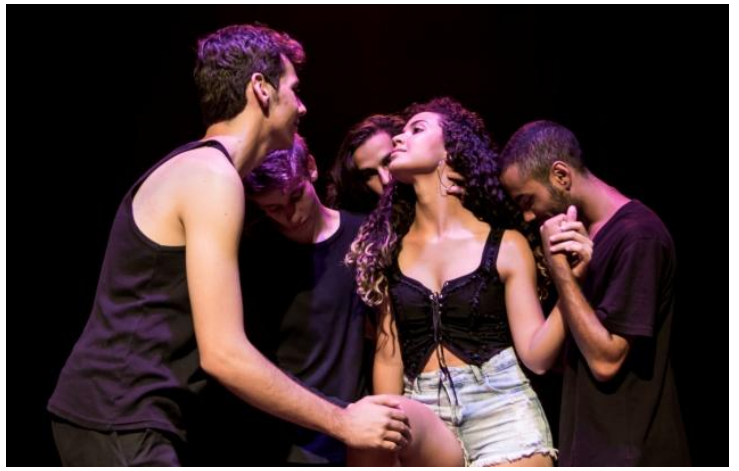

Foto 37

Fotografias de Sartory - Arquivo da Autora 
Eu morro, tu morres, ele morre,

Nós morremos, vós morreis, eles morrem.

Todos vocês morrerão.

Teu pai morre, tua mãe já morreu e minha filha, tadinha, Morreria se tivesse nascido.

Eu não pensava muito nisso não,

Mas aí eu parei pra observar:

Uma grávida nada mais é que

Um cadáver adiado que procria.

E o bebê é um defunto que ainda não nasceu.

Mas aí vai de cada um né?!

Procria quem quiser...

Eu sei que hoje eu tô bem...

(Trecho da peça: Murro em Ponta de Faca. Personagem: Maria)

Os questionamentos dos seis personagens denunciavam as imposições, perseguições e torturas praticadas pelo Estado. Seus posicionamentos políticos e o modo como reagiam à época de ditadura e de censura à expressão causavam divergências, conflitos e, por vezes, intolerância diante das diferenças dilatadas pelo convívio quase que imposto.

\section{$9^{\circ}$ Encontro - 08 de outubro de 2015.}

\section{1 - Vídeos - Recorte da historicidade do Teatro Brasileiro do século XX}

Descrição - Vídeos sobre Augusto Boal e sua trajetória.

Objetivo - Conhecer seu percurso artístico desde o Teatro de Arena, além de relatos sobre vários grupos que aplicam o Teatro do Oprimido, em destaque, o Teatro-Fórum.

Resultados - Em Angola e Moçambique, por exemplo, a aplicabilidade dessa técnica tem mobilizado um número significante de moradores, em destaque aos homens, a respeito da proliferação do vírus HIV na região.

\section{2 - Quatro em marcha $-5^{\text {a }}$ Categoria - a memória dos sentidos}

Descrição - Quatro participantes marchavam emitindo um som ininterrupto, como se fossem militares, até que um quinto participante tentava impedi-los dançando. Sem sucesso, foi posto para fora do espaço pelos quatro em marcha. Ele tentava novamente e a situação continuava a mesma; os quatro insistiam marchando como que estivessem 
cumprindo uma missão. O quinto participante desiste de propor algo diferente e se junta a eles, agora são os cinco participantes que marcham.

Objetivo - Esse jogo é a primeira demonstração de Cena-Fórum, elencada de uma série de demonstrações que ainda serão vivenciadas, a qual propicia ao grupo experenciar o propósito do arsenal do Teatro do Oprimido. Essa modalidade consiste na possibilidade de discutir situações de opressão e, principalmente, viabilizar maneiras de resolvê-las.

O Teatro do Oprimido não é um método cristalizado, mas um conjunto de técnicas que situa e prepara um grupo, por exemplo, a enfrentar ocorrências cotidianas que impedem seu livre arbítrio, que ferem sua identidade e que manipulam seu direito de ir e vir.

Os Quatro em marcha representam o opressor, e o quinto, que destoa do sistema, o oprimido. O restante do grupo é convidado a entrar no lugar do protagonista (oprimido) a propor soluções para esta situação: o que fazer para vencer esse sistema? Diante de um obstáculo como este, o que pode ser proposto para que a primeira ideia, de dançar, seja respeitada e incorporada a essa imposição? Será que existem outras possibilidades de desmembrar este quarteto e/ou de propor outro tipo de conduta que não seja o ato de marchar?

Resultados - O grupo já vivenciou algumas etapas dos jogos, as quais possibilitaram o acesso às cinco categorias. Isso gerou uma familiaridade com os termos opressor e oprimido, além da oportunidade de se colocarem e de discutirem conflitos que geravam opressão.

\section{3 - O Jogo do Poder - 4a Categoria}

Descrição - Nele foram utilizados objetos que se encontravam em espaços destinados à sala de aula: mesas, cadeiras e garrafinha de água. Esses objetos foram disponibilizados no espaço da seguinte maneira: uma mesa com uma garrafa em cima e seis cadeiras colocadas em frente à mesa. E a pergunta aos participantes foi lançada: onde estava o poder?

Objetivo - Em continuidade, as relações de poder sendo discutidas por meio dos jogos.

Resultados - Alguns disseram que estava na mesa - por ser um objeto que se encontrava disponibilizado na frente dos demais, além de ser único e imponente em 
relação aos outros que ocupavam o mesmo espaço. Outros disseram que o poder estava na garrafa, haja vista esse objeto estar sobreposto ao outro que exercia uma liderança em relação aos demais.

Como em um tribunal, cada um poderia exercer o papel de juiz e mudar a ordem estabelecida, podendo assim transferir o poder para qualquer um dos objetos postos no jogo. Muitos participantes se manifestaram e o modo como distribuíram o poder, e/o transferiram possibilitou a tentativa de discursar sobre a estrutura de poder imposta e a importância de se ter ferramentas para modificá-la. Caso não tenha como mudar a estrutura, pelo menos cria-se a tentativa de discutir sobre e estabelecer possíveis alternativas de mudanças.

Destaco algumas propostas:

- um participante colocou a mesa para baixo, a garrafa caída no chão e todas as mesas empilhadas uma sobre a outra transferindo o poder para as cadeiras, ou seja, para a maioria, para os menos favorecidos;

- outro optou por colocar todos em círculo, com objetivo de exercer a democracia e a igualdade. Porém, a mesa continuava ali e a garrafa também destoando das demais, ainda exercendo mais poder do que todas as cadeiras;

- outro participante mudou a ordem: dispôs as cadeiras na frente e a garrafa sobre a mesa ao fundo. Alguns se manifestaram ponderando que o poder continuava na garrafa e na mesa; elas pareciam que estavam de vigia, logo, continuavam exercendo o poder sobre as cadeiras situadas à frente.

Esses são alguns exemplos de como esse jogo permite a reflexão de possibilidades infinitas de discutir e intervir nas estruturas pré-estabelecidas de domínio de situações, na imposição de regras, na limitação do direito de ir e vir. É um jogo que utiliza de objetos que fazem parte do cotidiano escolar, logo, há uma identificação por parte dos participantes/estudantes e uma associação com o cotidiano deles. E, principalmente, a oportunidade de sair da inércia, de deixar de ser omisso e submisso, como destaca Paulo Freire em seu livro Educação e mudança (2010, p. 35): 
É preciso partir de nossas possibilidades para sermos nós mesmos. O erro não está na imitação, mas na passividade com que se recebe a imitação ou na falta de análise ou de autocrítica.

\section{$10^{\circ}$ Encontro - 15 de outubro de 2015.}

\section{1 - Análise da peça teatral}

Descrição - Análise da peça teatral: Revolução da América do Sul.

Objetivo - Analisar duas peças de Augusto Boal escritas em épocas e contextos diferentes.

Resultados - Os alunos destacaram a atualidade do texto, o descaso com a miséria e a ironia, presente na dramaturgia, de tirar proveito daqueles que mais são prejudicados socialmente. Foi notória a comparação do personagem José da Silva (protagonista) com vários "Josés" em nosso convívio. Uma das cenas do nosso espetáculo trouxe alguns questionamentos provenientes das relações de poder abordadas nessa peça.

Compactuo com a pesquisa de Pupo (2005) sobre a prática do jogo teatral para a leitura no teatro, em suas experiências no Brasil, na França e em Marrocos, que resultou no livro Entre o Mediterrâneo e o Atlântico, uma aventura teatral. A autora ressalta que a abordagem lúdica no teatro perpassa pela proposta do jogo, do texto, dos personagens e do espaço, somando a um discurso dramático que um determinado grupo assume e estabelece como consequência a comunicação com a plateia.

Uma das etapas de seu trabalho com os marroquinos vai ao encontro com a sistematização proposta por Boal no que se refere à lógica dos jogos em dividi-los em categorias. Essa divisão contribui no entendimento da proposta do Teatro do Oprimido em aliar os elementos que compõem a linguagem teatral ao ato de se colocar e possibilitar a resolução de tipos de pendências, de conflitos sociais e das relações interpessoais.

$11^{\circ}$ e $12^{\circ}$ Encontros - 22 e 29 de outubro de 2015.

1 - Canovaccio - roteiro de ações

Canovaccio indica os elementos básicos da trama de uma peça, sem entrar nos detalhes de cada cena. Nele consta o tema, a descrição das situações e as personagens 
intervenientes. A partir desses elementos, desenvolve-se a improvisação dos atores. Esse tipo de roteiro muito simples surge aproximadamente no século XVII, permanecendo até o XVIII, e constitui a base da Commedia dell'Arte.

Descrição - Pedi que eles se dividissem em grupos e trouxessem um roteiro a partir das cenas que foram improvisadas nos encontros anteriores, além de criar outras com base no que foi vivenciado até o momento.

Resultados - Quatro participantes se manifestaram de início e propuseram seu respectivo roteiro, exercendo a função de direção na condução das cenas. Eles poderiam aproveitar as improvisações criadas ao longo da oficina e propor a criação de outras desempenhando a função de dramaturgos.

Como exemplifica um dos adolescentes:

Ao longo do segundo mês, as histórias começaram a surgir e nos deparamos com um espetáculo, não cênico, um espetáculo real, das nossas vidas. A partir daí vieram então às montagens de pequenas cenas. Eu sempre quis expressar algumas ideias que eu tinha para as cenas, aquele era o momento perfeito. Apresentei o que tinha em mente e, junto com meus amigos, montamos um grande roteiro (T. N.,17 anos).

Era interessante vê-los protagônicos diante do que estávamos construindo. Vêlos transformando as histórias escolhidas em cenas que continham seus posicionamentos. Vê-los se apropriando dos jogos através de suas falas, posturas, construção de argumentos e síntese.

$13^{\circ}$ ao $16^{\circ}$ Encontro-de 05 a 14 de novembro de 2015.

\section{1 - Ensaio dos Canovaccios}

Descrição - A proposta dos canovaccios foi decidida pela maioria dos participantes, de modo que, quem não propôs o roteiro de cenas, se sentiu contemplado por aqueles que quiseram vivenciar a criação e direção de cenas.

Objetivo - Criação da dramaturgia do espetáculo. 
Resultados - Inicia-se o processo de construção de cenas, é quando o roteiro começa a ser desenhado.

$17^{\circ}$ Encontro - 19 de novembro de 2015.

\section{1 - Improvisação de Cenas}

Descrição - Propostas de outras improvisações sobre temas que ainda não tinham sido abordados.

Objetivo - Observar todo material levantado e preencher as lacunas com outras cenas que ainda não foram contempladas no processo.

Resultados - Após elencado as cenas, observei as brechas existentes e propus-lhes a criação de outras cenas que abarcasse todos os temas debatidos.

$18^{\circ}$ Encontro - 21 de novembro de 2015.

\section{1 - Definição do roteiro e o nome do espetáculo: Transições de Impacto}

Descrição - Definir o roteiro para a consolidação da peça e do título.

Objetivo - Criação da estrutura dramatúrgica.

Resultados - Nesse momento da oficina, assumi mais precisamente a condução do processo: dividi com eles minhas observações e lancei para os ensaios que ainda restavam, a sequência que montei das cenas. Defini também o título delas, além de me apropriar de algumas denominações de cenas que foram sugeridas durante os canovaccios.

Observei que as cenas eram impactantes, que eles estavam muito entregues e entusiasmados com as discussões colocadas de forma artística gerando, assim, uma ansiedade de como iriam dialogar com a plateia sobre os temas levantados. Diante desses fatos, sugeri que o nosso espetáculo fosse chamado: Transições de Impacto! Todos concordaram e se sentiram contemplados.

Os ensaios que seguiram, tiveram a função de registrar as marcas das cenas, falas que, embora tenham surgido de improvisações, tendiam naturalmente a passar pelo processo de memorização, na medida em que eram repetidamente ensaiadas. Nesse tipo de processo, o foco não estava em construir primeiramente o texto, longe da prática, 
decorá-lo e depois começar a experimentá-lo. Pelo contrário, das improvisações, das criações, da prática, o texto surgia meio que automaticamente e os ensaios ajudavam o processo de registro e de consolidação do mesmo.

O importante nessa etapa da oficina, além de contemplar a maior parte do que experimentamos, foi estruturar a criação para o Teatro-Fórum. Ou seja, as cenas tinham as características de serem independentes, porém tive a preocupação de inserir algumas cenas entre, as independentes, que se tratavam das mudanças ocorridas com os personagens chaves: o opressor e o oprimido. No nosso caso, escolhemos a opressora (avó) e o oprimido (neto).

Montamos uma sequência da trajetória desses personagens para que o público estabelecesse uma ligação entre eles e compreendesse as situações de opressão presentes e os conflitos que surgiam dessas relações de poder encenadas. O objetivo era conduzi-los até o momento em que há o embate entre esses dois personagens, de modo que o público queira intervir no lugar do oprimido e propor soluções. Conforme relata a adolescente que interpretou a opressora:

Então montamos um espetáculo que superou todas e quaisquer expectativas iniciais. Confesso que, como opressora mor, me bateu um medo de não saber o que fazer e de não conseguir atuar com alguém da plateia. Mas a oficina é tão completa que ela em si já te dá segurança o suficiente para estar no palco com qualquer um a qualquer momento (D. A., 17 anos).

Realizamos técnicas de ensaio que os preparava para o momento fórum. $\mathrm{O}$ processo permitiu também que eles construíssem os personagens na perspectiva de ultrapassar a ficção, ou seja, eles eram capazes de improvisar mediante situações inesperadas vindas do espect-ator.

Além disso, entendemos o nosso personagem de uma forma muito profunda pelo modo como criamos o texto da peça. Nada escrito, nada decorado, apenas improvisado. Decidimos escrever o roteiro nos últimos ensaios apenas para definir alguns objetivos importantes que não poderiam se perder em meio a tanta improvisação (D. A., 17 anos). 
Essa adolescente, em específico que interpretou a opressora percebeu que o improviso contribuía para entender melhor a sua relação com o espect-ator. Uma vez que o público tinha a possibilidade de intervir na problemática encenada.

Tivemos que introduzir o espectador no espetáculo com o olhar, sempre buscando essa triangulação para que ele se sentisse parte da cena a ponto de querer mudar a situação ali apresentada. Um pouco difícil no começo, mas profundamente prazeroso no final (D. A., 17 anos).

$19^{\circ}$ ao $21^{\circ}$ Encontro - de 26 de novembro a 02 de dezembro de 2015.

\section{1 - Ensaios do roteiro}

Descrição - Os próximos encontros foram destinados a ensaios, ajustes no cenário, definição de figurinos, iluminação e sonoplastia.

Objetivo - Minha opção estética para esse espetáculo foi mantê-los em cena durante toda a apresentação, dialogando com a plateia por meio do texto, do olhar e das ações em cena. Dirigi-o na perspectiva de criarem a triangulação com o público e que este os visse ora personagem, ora atores. As músicas em cena tinham o caráter de continuidade com o texto dramático, assumindo a função de comentar sobre ele.

Resultados - Todos faziam mais de um personagem, exceto um deles que fez o papel do Coringa. Sua caracterização era diferenciada, tendo a função de narrar e comentar sobre o espetáculo, além de informar e dar ênfase em alguns conflitos que evoluíam até chegar a Cena-Fórum. "Partimos do princípio básico do Teatro do Oprimido, atos de opressão, protagonizado por nós mesmos” (H. G., 18 anos).

Figura 12 - Cena: Gira a Roleta.

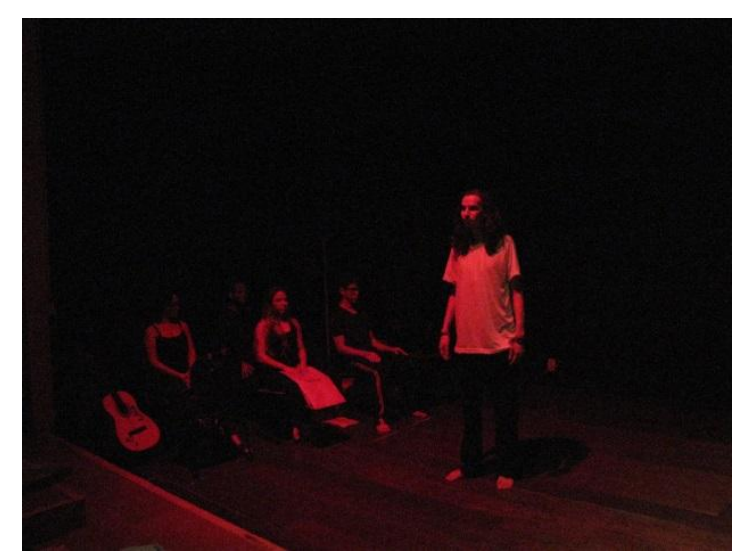

Foto 38

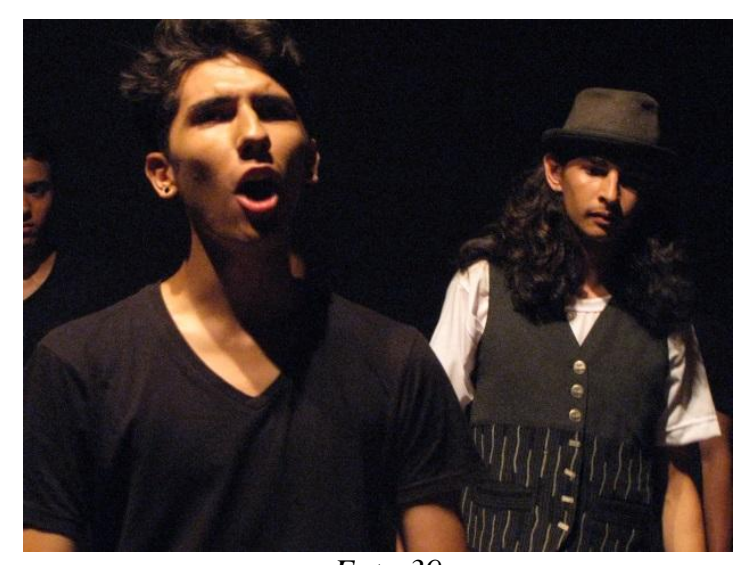

Foto 39 


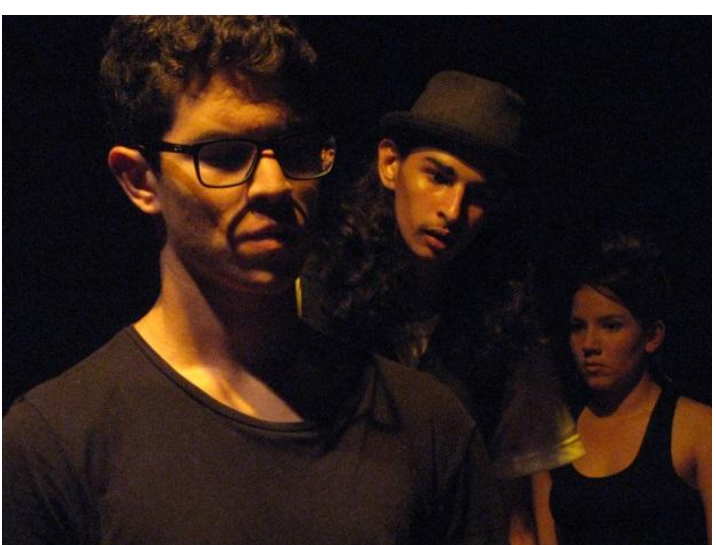

Foto 40

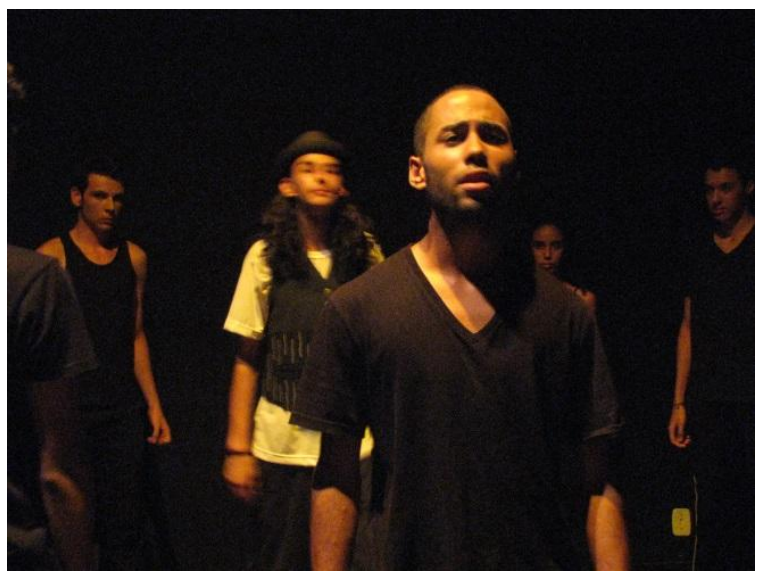

Foto 42

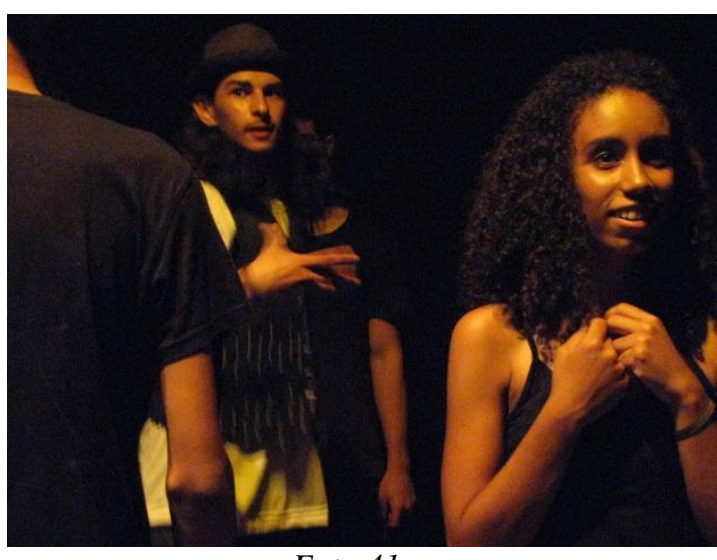

Foto 41

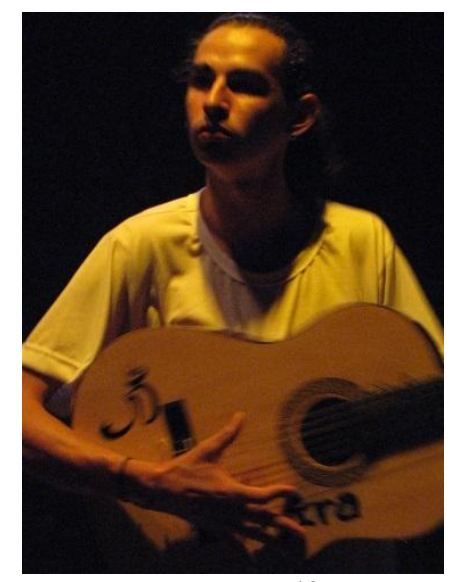

Foto 43

Fotografias de Hugo de Freitas - Arquivo da Autora.

$22^{\circ}$ ao $25^{\circ}$ Encontro - de 03 a 08 de dezembro de 2015.

\section{1 - Apresentações do Teatro-Fórum Transições de Impacto}

Descrição - Chegou o momento de compartilhar com o público o que escolhemos discutir por meio do teatro.

Objetivo - Vivenciar o jogo cênico, a arte de interpretar, de discutir através do TeatroFórum temas que nos são pertinentes e que ainda valem serem colocados em cena para serem conscientizados e transformados, se possível.

Resultados - A participação da plateia durante todo o espetáculo foi de cumplicidade. As intervenções diante do problema encenado trouxeram soluções que justificaram a relevância em abordar relações de poder exercidas com crianças e adolescentes. Muito do que eles trouxeram para serem debatidos em cena gerou identificação imediata por parte do público, transformando o Teatro-Fórum em um espaço de intervenção e de modificação da realidade. 
Pra mim todos foram protagonistas no "Transições", onde cada um tinha a importância de mostrar um ponto de vista sobre o tema (opressão na família). E esse "protagonismo" me ajudou a me cobrar mais como ator, correr atrás e pesquisar muito (P. C., 17anos).

Vale ressaltar que os depoimentos dos adolescentes inseridos em minha pesquisa foram recolhidos depois que pedi que cada um escrevesse o que mais os impressionou diante dessa experiência que tiveram com o Teatro do Oprimido. A maior parte dos participantes me enviaram e-mails, no qual pude reorganizá-los e subdividi-los junto com minhas observações diante dessa rica vivência.

$26^{\circ}$ Encontro - 10 de dezembro de 2015.

\section{1 - Avaliação da Oficina.}

Descrição - Avaliação de todo o processo e entrega do Certificado.

Objetivo - Avaliar todo o processo vivenciado nesses três meses de trabalho.

- Como foi vivenciar a Oficina de Teatro do Oprimido?

- O que acharam de apresentar um Espetáculo-Fórum?

- Vocês acham que esse processo possibilitou que adquirissem mais autonomia, pensamento crítico e ações protagônicas?

Resultados - Essas perguntas nortearam a avaliação. As observações feitas a partir de suas respostas, assim como a análise do espetáculo, encontram-se na segunda parte desta pesquisa.

Portanto, na parte seguinte, apresento o trabalho desenvolvido junto aos alunos do grupo Oprieram. 


\section{PARTE II - DA IMPROVISAÇÃO AO DIÁLOGO}

Augusto Boal (2005) defende que o teatro é um espaço democrático. Quando ele cria o Teatro do Oprimido, direciona a utilização da linguagem teatral como transformação pessoal, política e social, que pode ser apropriada por aqueles que se encontram em situações de opressão. Com isso, é possível transformar o espectador em sujeito, isto é, em ator no sentido de ser transformador da ação dramática, logo, sujeito transformador da sua vida.

Quando ele afirma que o teatro é a imitação da realidade, abre-se o precedente de que essa linguagem pode ser utilizada como forma de expressão social, pois reflete aquilo que é vivido fora dos palcos. Possibilita, inclusive, que as camadas mais populares deixem de ser apenas plateia, mas protagonistas de cenas que refletem seu cotidiano, de modo que essas experiências vivenciadas sirvam como aprendizado para transformar a realidade. Ao assumir a arte como um processo de se obter prática criadora e crítica, Boal assegura o direito de todo ser humano à formação estética, pelo fato de a arte viabilizar o sujeito com instrumentos para entender e analisar a sociedade e emancipar-se.

O termo teatro permite infinitas possibilidades de ser utilizado e, como Boal frisa em sua extensa obra, através do teatro é possível fortalecer instâncias populares, ao permitir rupturas nos modos de opressão social. Assim, reivindico um espaço de desenvolvimento da aplicação do Teatro do Oprimido no ambiente escolar, de modo que esse tipo de linguagem emancipe os alunos no que tange sua formação como indivíduos críticos e protagônicos.

Para Boal, o Teatro-Fórum caracteriza-se como um espaço de participação ativa, de exercício da autonomia e de produção de diversidade de sentidos, uma vez que essa vivência favorece tanto a quem participa do processo como ator, como àqueles que vivenciam como espectador. Este último tem recebido atuais estudos na área da recepção, a exemplo de autores como Hans Robert Jauss em A Estética da Recepção: colocações gerais (2002) e Luis Cláudio Cajaíba em Espectador: contemplar ou ser contemplado? (2010), que dialogam com a perspectiva apresentada no Teatro-Fórum no que tange a relação do espectador com a obra de arte. 
Nesse contexto, isso significa que o sentido que se dá a uma obra de arte varia de acordo com a sensibilidade do espectador. E, ausente de julgamentos, é possível perceber que sua recepção não é apenas contemplativa e, sim, permeia um lugar de produtividade perante o que se assiste. O autor Luigi Pareyson - em seu livro Os problemas da Estética (1997) analisa que a sensibilidade do espectador é acompanhada de suas experiências sociais e estéticas que ultrapassam a tecnicidade do artista presente em sua obra artística. Nesse caso, percebo a semelhança com os pensamentos de Augusto Boal, quando ele frisa, em seus escritos e práticas, que o termo espect-ator coloca o sujeito capaz de interpretar, avaliar e interferir em uma obra teatral.

Sendo assim, a soma de experiências anteriores de um sujeito com seus valores políticos e, valores estes que tem uma porcentagem considerável adquirida durante sua trajetória, influenciam em como esse sujeito irá ler e interpretar uma obra de arte; é o que o Jauss em sua outra obra A história da literatura como provocação à teoria literária (1994) irá chamar de horizonte de expectativas. Com isso, a apreciação e a interpretação de uma obra artística variam de um sujeito para outro, a partir de suas vivências e experiências adquiridas.

Em se tratando da experiência estética, acredito que o Teatro-Fórum abranja uma produção de diferentes sentidos para cada sujeito perante uma obra artística. E, mais, seus sentidos são revistos tanto para aqueles que participam de um processo metodológico que envolve o Teatro do Oprimido como um todo, até chegar ao TeatroFórum propriamente dito, como aqueles que apreciam a obra no momento de sua apresentação teatral.

\section{1 - DRAMATURGIA DO TEATRO-FÓRUM}

Na dramaturgia do Teatro-Fórum, motivação e caracterização são essenciais. A primeira é a expressão do querer do personagem: o que ele quer. É a vontade do personagem que deve guiar suas ações. A caracterização, por sua vez, é a maneira como o personagem demonstra esse querer: de forma grosseira, romântica, engraçada, séria, etc. Os personagens podem assumir variadas formas de comportamento para fazer valer sua vontade, mas o fundamental é que essa vontade esteja clara. 
Um espetáculo pode estar bem trabalhado no que se refere à caracterização, mas isso não garante que fique clara a motivação dos personagens. Caracterização sem motivação transforma o espetáculo em um corpo invertebrado. Tão importante quanto saber quem são os personagens, é definir o que querem. Cada personagem deve ser a expressão de uma vontade prioritária.

O conflito é a demonstração de como o opressor impede a realização da vontade do protagonista e da luta do oprimido para que ela seja alcançada. No Teatro-Fórum, perguntam-se quais são as alternativas para que o protagonista seja bem sucedido na realização de sua vontade. A estrutura da cena deve ser definida na relação das vontades dos personagens (opressor e oprimido). A luta pelas vontades contraditórias desenha o desenvolvimento da ação dramática até a crise chinesa (perigo + oportunidade).

O espetáculo precisa começar longe dessa crise, sendo iniciado na contrapreparação: momento ainda distante da crise, onde parece que tudo dará certo para o protagonista. Dessa forma, o ápice do conflito fica afastado do início da peça, permitindo que a plateia se surpreenda com seu surgimento. Desenlace é o momento final da cena, quando aponta a falha do protagonista e o insucesso em sua empreitada.

Conforme explicita a imagem a seguir:

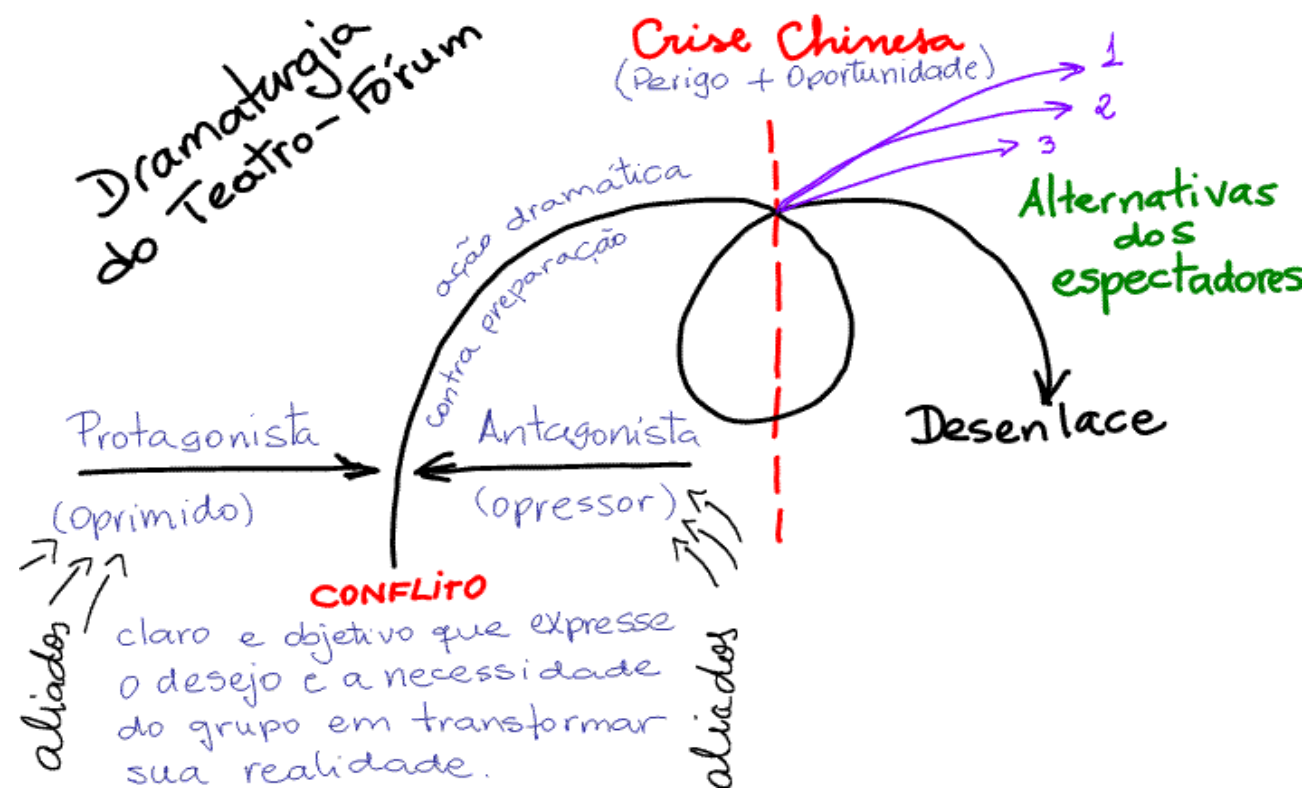

Essa ilustração foi feita pela Curinga do CTO - Helen Sarapeck, na ocasião em que participei do Seminário de Multiplicadores do Teatro do Oprimido em fevereiro de 2008. 
De acordo com o que foi apresentado anteriormente, o caminho metodológico que perpassa pelos jogos teatrais já tem como objetivo trabalhar os cinco sentidos dos participantes, de modo que o corpo possa ser desmecanizado e tornou-se apto para o trabalho criativo pautado na linguagem teatral. A partir desse ponto de produtividade, é inserido no trabalho de um grupo de sujeitos-participantes o aprofundamento de uma das técnicas do arsenal do Teatro do Oprimido. Neste caso, está sendo analisada e vivenciada a técnica do Teatro-Fórum que consiste em dois momentos: o daqueles que fazem a obra artística pelo viés do ator e o daqueles que a contemplam e completam a partir da experiência do espectador.

Nesse momento, é possível associar o trabalho desenvolvido no Teatro-Fórum com uma dimensão política, por colocar o sujeito frente a uma realidade teatralizada, permitindo que ele intervenha e busque resolver problemas específicos de opressões entre os personagens. Isso é o que Paulo Freire, em Pedagogia da Autonomia: saberes necessários à prática educativa (1996), vai chamar de um mecanismo educacional para a autonomia, uma vez que o sujeito se sente livre para intervir e modificar na perspectiva do personagem oprimido, com a qual ele se identifica. Essa identificação ocorre porque o que é posto em cena retrata conflitos sociais através da apreensão estética, criando a empatia que gerará, como consequência, a vontade de agir, de modificar e de contribuir para o fechamento da obra artística.

Em seu estudo sobre a Formação em Teatro-Fórum: recepção, intervenção e autonomia do espectador (2013), Cilene Canda salienta que:

As intervenções em uma cena de Teatro-fórum são frutos de um processo de fruição da obra teatral pelo espectator, e envolvem questões como a formação, as experiências anteriores em determinado contexto social e a produção ideológica perante o mundo (2013, p. 131).

Essas intervenções permitem que o sujeito exercite uma postura diante da cena que o leve a interpretá-la criando a necessidade de intervir, ao se colocar no lugar do oprimido no espaço cênico. Boal em seu livro $O$ teatro como arte marcial (2003) complementa frisando que o espectador torna-se, então, um protagonista insubmisso ao se colocar em cena no papel do outro, mas falando de si, do seu ponto de vista em 
relação ao problema encenado; interferindo consequentemente, no produto final do espetáculo.

Em seu artigo, Canda (2013) acredita que as ideias defendidas por Boal podem ser dialogadas com as pesquisas desenvolvidas sobre a recepção teatral. Com isso, o espaço cênico torna-se um campo fértil às concepções de espetáculos polissêmicos, isto é, abertos a diversas intervenções. Percebo, portanto, uma similaridade com o conceito de espect-ator defendido por Boal com o espectador contemporâneo, no instante em que ambos apreciam, dialogam, intervém e se reinventam dentro de uma obra artística. Como a autora defende:

Nesse cenário, o objetivo da participação do espect-ator não se dá na decifração de uma verdade ou na contemplação de um modelo performático pronto e acabado, mas se efetiva no acesso a códigos estéticos e na interpretação da multiplicidade de signos da composição do espetáculo (CANDA, 2013, p. 131).

A forma como é encenado esses signos de composição, permite que o espectador se sinta motivado a interferir diante da obra que assiste, deixando de ser mero contemplador do espetáculo em si. E, para Boal, percebo que sua militância consiste em criar um espaço no qual o espectador ressignifique, observe e crie a ação teatral.

O Teatro-Fórum possibilita ao sujeito o encontro e o confronto consigo mesmo e com situações que podem ser modificadas a partir do ambiente que é criado para que ele possa intervir. Ao se sentir atuante, o sujeito exerce a política, que consiste em obter o que deseja diante de assuntos particulares, mas que gera uma ação coletiva e reflete em mudanças de sua realidade e do que está em sua volta. Como relata um dos adolescentes que participou da Oficina de Teatro do Oprimido:

Hoje eu entendo um pouco mais sobre o teatro fórum, que é você mostrar um problema social que cause indignação no público, onde o mesmo pode encontrar uma solução. E pra mim essa foi a parte mais interessante do processo, aonde vimos que pode haver várias ideias sobre o mesmo assunto (P. C., 17 anos). 
Por entender que o Teatro-Fórum é um espaço no qual o sujeito se posiciona, trabalha seus sentidos e a multiplicidade de leitura perante uma obra de arte, além da possibilidade de intervir sobre ela, destaco e analiso três intervenções dos espectadores no espetáculo Transições de Impacto do grupo Oprieram. As técnicas presentes no arsenal do Teatro do Oprimido procuraram oferecer aos participantes um espaço no qual eles pudessem refletir e se pronunciar em relação a situações que os incomodavam em seus cotidianos. Era um espaço no qual o que lhes causava opressão podia ser expresso e trabalhado a partir dos objetivos propostos em cada jogo teatral. Como menciona uma das adolescentes que, dentre alguns personagens, interpretou a opressora:

CHEGAMOS. É hoje. Como será? Dizem que vamos interagir com a plateia. Será que a gente consegue? Que medo! - dizíamos uns aos outros. Mas, apesar disso, esse sentimento de desconhecido durou pouco. Logo nos apropriamos do tal Teatro do Oprimido (D. A., 17 anos).

O universo do nosso espetáculo Transições de Impacto (foto 44) permeou a infância, o abandono de pais e/ou responsáveis, a violência doméstica e o trabalho escravo que, para eles, todos se perpetuam em suas lembranças e repercutem em suas linhas de pensamentos e condutas que afloram, com mais ênfase, nesta fase da adolescência (fotos 45, 46, 47, 48 e 49). Como esse período é uma transição na trajetória de qualquer sujeito, o processo de criação de cenas deu-se sobre o olhar dessa transição e a intenção em ressaltar as marcas da infância que valiam a pena ser encenadas e colocadas em discussão:

Já no começo descobrimos um denominador comum que angustiava a todos: a infância. A partir disso criamos uma garra nunca sentida por nenhum de nós até então. Uma garra de estar mostrando não só a si mesmo em cena, mas também a tantos outros oprimidos sem voz espalhados por aí (D. A., 17 anos). 
Figura 13 - Cartaz do Espetáculo e Cena: Aconteceu Comigo.

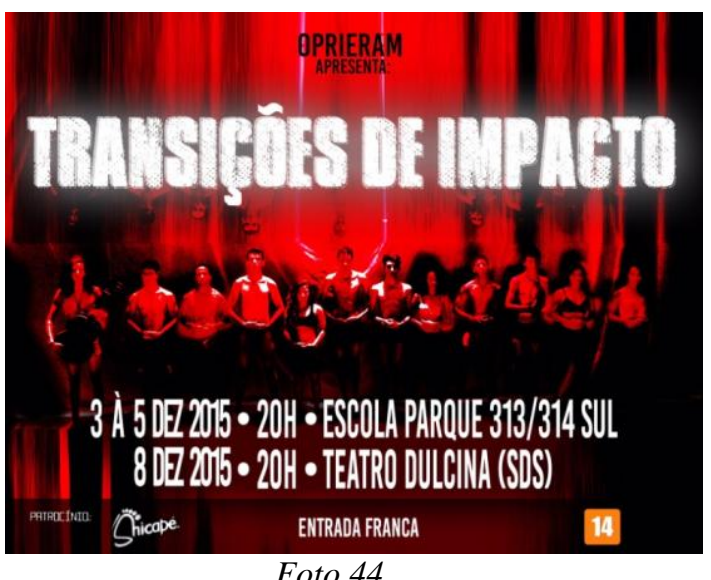

Foto 44

Arte de Nathan Nagashima

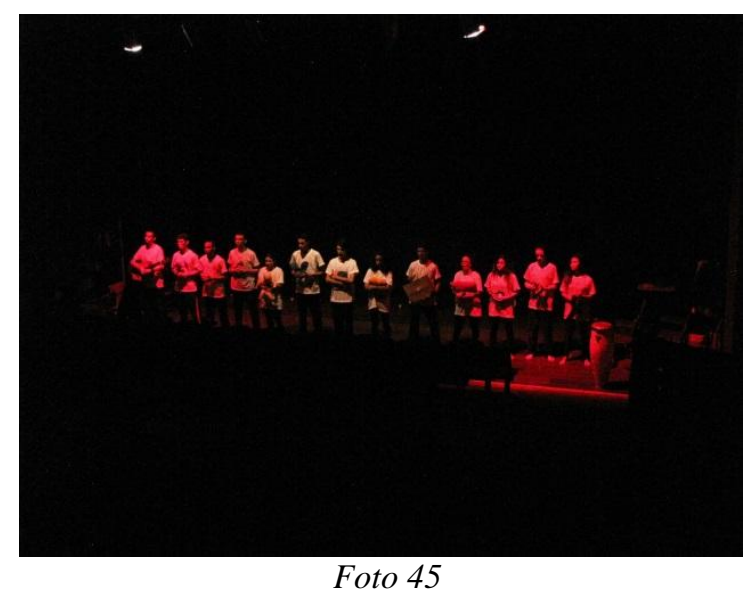

Fotografia de Hugo de Freitas

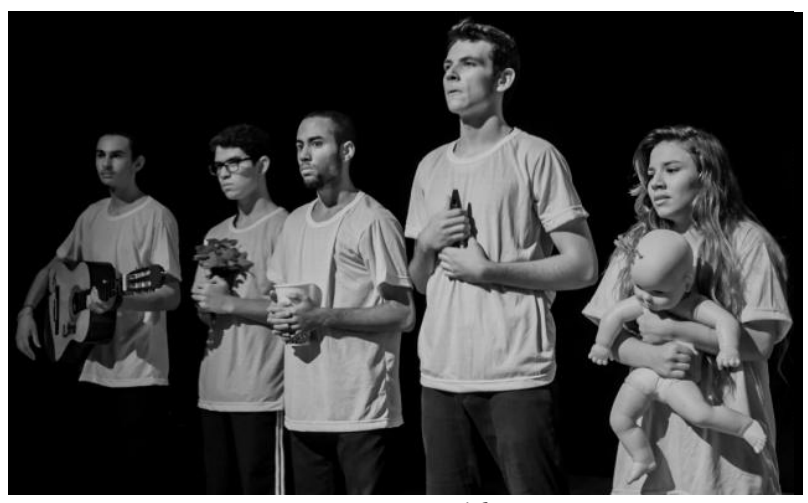

Foto 46

Fotografia de Sartory

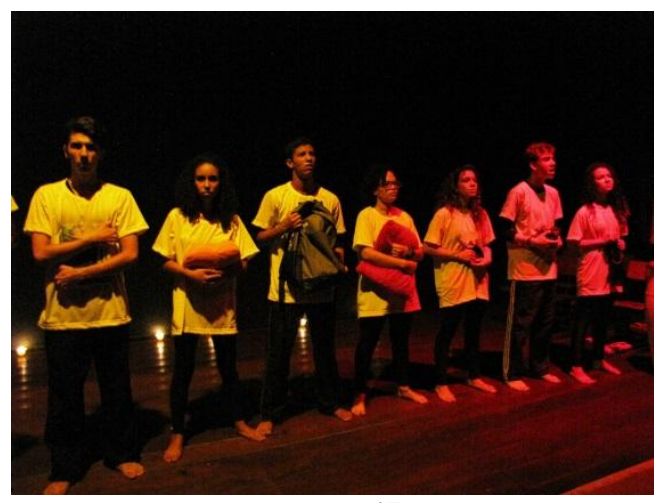

Foto 47

Fotografia de Hugo de Freitas

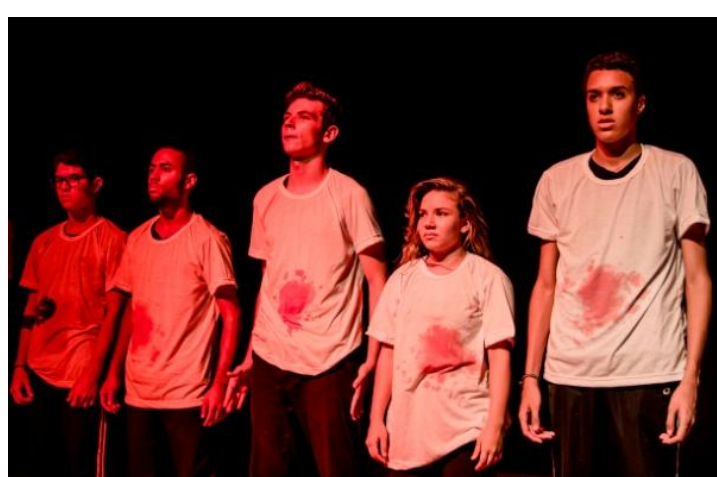

Foto 48

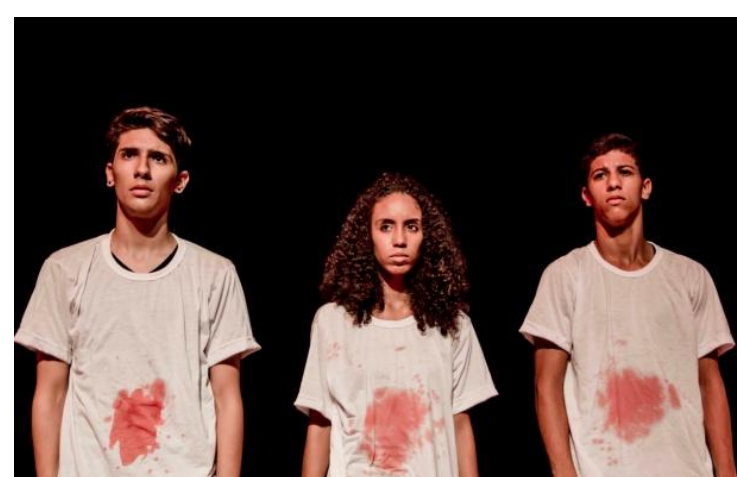

Foto 49

Fotografias de Sartory - Arquivo da Autora

O processo de criação começou a partir de improvisações de temas que norteavam esse universo. O nosso roteiro final foi realizado a partir de um canovaccio roteiro de ações. O texto foi construído durante as improvisações, pois no nosso processo, as palavras foram naturalmente decoradas pelos atores a cada ensaio. De início, o que foi escrito foram os títulos das cenas e cada uma delas, automaticamente, continha palavras e/ou frases-chave que conduziam os atores nas cenas, sendo firmadas 
nos ensaios e no espetáculo em si. As marcações também ajudavam este processo natural de construir e decorar o texto ${ }^{4}$ concomitantemente.

Pupo acrescenta:

(...) a construção teatral por meio de fragmentos textuais traz para o primeiro plano o não acabamento, a descontinuidade, a elipse. Procedimentos de colagem e de cruzamento de diferentes textos em função de temas, autores ou estilos de escrita permitem a emergência de novos e enriquecedores significados (2005, p. 27).

Várias propostas de canovaccios foram experimentadas. Foi um momento na oficina de muito aprendizado e dedicação, no qual a maior parte dos participantes exerceu a função de dramaturgos e de diretores de suas respectivas propostas de roteiro de ações. O restante exercia a função de atores, não apenas no sentido de executar cada roteiro, mas, principalmente, de criar a partir dos apontamentos da direção.

A autonomia exercida durante esse processo, em específico, o envolvimento em vivenciar e experimentar os elementos que compõem a linguagem da encenação e a oportunidade de se colocarem, de debaterem artisticamente situações de conflito, vai ao encontro da experiência de Marcos Bulhões Martins em sua pesquisa Encenação em jogo: experimento de aprendizagem e criação do teatro (2004, p. 138) realizado com um grupo de estudantes de graduação em Artes Cênicas - USP:

Buscamos uma dramaturgia de caráter coletivo que, além de ser um meio para a formação de um discurso, fosse um experimento sobre a natureza humana que visa modificar os que a realizam.

A pesquisa de Martins permeou as possibilidades do jogo em espaços e fragmentos de textos como forma de elaboração da dramaturgia e da encenação, o que resultou no espetáculo 1999. No nosso caso, percorremos o caminho de entendimento da utilização da linguagem teatral sobre a ótica defendida por Boal, que consiste em discutir relações de opressão e a possibilidade concreta de mudanças por meio do teatro.

$\mathrm{Na}$ tabela a seguir, apresento o roteiro das cenas desenvolvidas neste trabalho:

$4 \quad$ O texto da peça, resultado do nosso processo, segue em anexo. 


\section{$\underline{\text { Roteiro das Cenas }}$}

1. Aconteceu comigo... - Elenco todo.

2. Música.

3. Jogo de Cartas.

4. Luz de Velas - Elenco todo.

5. Avó com Cartaz - Estatística.

6. Oprimido Rejeitado.

7. Respiro I - Totalmente Incompreensível!

8. Puta.

9. Blackout. Estupro.

10. Respiro II - Totalmente Incompreensível!

11. Coringa.

12. Relação Amorosa.

13. Cartaz - Abandono.

14. Surra na Alma.

15. Oprimido Expulso.

16. Gira a Roleta.

17. Mãe e Filha - Quadriplicada.

18. Respiro III - Totalmente Incompreensível!

19. Estupradinho.

20. Escola.

21. Morte Passeia.

22. O Confronto - Cena-Fórum. 
23. A Retomada - Elenco todo.

Nas apresentações do Teatro-Fórum, o momento que antecede o espetáculo é apontado pela atuação do Curinga do Teatro do Oprimido - que é o intermediador do que será exposto, fazendo a condução da problemática levantada em cena e, consequentemente, do diálogo entre atores e espectadores.

Antônia Pereira Bezerra, em sua pesquisa sobre $O$ Teatro do Oprimido e a Noção de Espectador - Ator: Pessoa e Personagem (1999), analisa que o Curinga do Teatro do Oprimido se assemelha ao Curinga da carta de baralho por exercer diferentes funções dentro do jogo lúdico. Primeiro, que ele é um multiplicador dessa metodologia; segundo, que ele exerce a função pedagógica por ser a ligação entre palco e plateia, investigando as estruturas interligadas de opressões manifestadas em cena com o intuito de combatê-las; e, em terceiro, que ele pode atuar, dirigir cenas, ministrar palestras, criar e coordenar projetos aliando o Teatro do Oprimido.

Exercendo uma função pedagógica, maiêutica, o Curinga, num espetáculo Fórum, assume o papel de conciliador, mediador do jogo. A interação palco e plateia, sob o olhar vigilante do Curinga, transforma o fenômeno da representação na soma das tentativas e soluções propostas pelos espectadores, com o objetivo de lutar contra uma determinada opressão (BEZERRA, 1999, p. 501).

No Teatro do Oprimido, Boal passou a utilizar o Curinga como um facilitador, um multiplicador de todo o arsenal que culmina em abordar e discutir conflitos sociais através da teatralidade, configurando dois prismas: o opressor e o oprimido. Assim, o Curinga conduz os jogos, dirige cada técnica e cenas a depender das demandas, além de disseminar a teoria e prática do Teatro do Oprimido.

Eu, como Multiplicadora do Teatro do Oprimido, fiz o curingamento e expliquei que se tratava de um espetáculo aberto, no qual seria levantada uma problemática e que eles, a plateia, seria convidada a resolver o problema como espect-atores. Para isso, utilizei algumas dinâmicas para preparar e situá-los e demos início ao espetáculo Transições de Impacto. 
Jogos, improvisos, cenas e a cada encontro as emoções eram intensificadas. Entendemos que o teatro-fórum torna o espectador um "espect-ator". Que ninguém precisa ser ator para estar em cena. Principalmente para dar voz a um oprimido. Sentimos a força que o TO exerce sobre seus executores. Sentimos como ele muda a estrutura dramática do ator, que é levado a colocar o seu coração em cena através das suas sociais, revoltantes e cotidianas circunstâncias dadas. Sentimos no corpo. Sentimos em casa. Sentimos na escola. Sentimos o TO em todos os lugares por onde passávamos, pois ele também mexeu com a nossa visão sobre o mundo. Os conflitos sociais do dia-a-dia sempre me motivavam a levar o TO para a maior quantidade de pessoas possíveis. $\mathrm{Na}$ escola principalmente (D. A., 17 anos).

A estrutura dramatúrgica do espetáculo aproximou-se com o que Brecht (2005) defendia no sentido da quebra da ilusão e também da linha linear de ação. As cenas eram independentes e as canções no decorrer da peça tinham o propósito de comentálas, ou seja, faziam parte do texto não para ambientalizar as cenas, mas para reforçar o discurso dos personagens intercalando ora texto, ora canções.

O objetivo dessa estrutura era alimentar o discurso de Brecht no sentido de mostrar para os espectadores que eles estão diante de um espetáculo teatral e que o que está sendo vivenciado e discutido em cena parte de uma escolha estética da diretora/grupo que assume um tipo de recorte para abordar determinado tema. Com isso, assume-se a não ilusão, dando lugar para a discussão teatral em relação ao assunto abordado.

As cenas são independentes e falam sobre as relações de poder exercidas entre o núcleo familiar, além de conflitos existentes em casa e na escola. A Cena-Fórum escolhida foi entre dois personagens: a avó (opressora) e o neto (oprimido), este sofre diversas humilhações por parte da avó que o acolhe em sua casa, obrigada, depois que o neto foi expulso de casa pela mãe.

No transcorrer da peça, o conflito entre os dois foi encenado em três momentos, intercalando-se com outras cenas, de modo que o público acompanhou a trajetória do oprimido dentro do espetáculo, mantendo certa cumplicidade com o protagonista, incluindo suas tentativas de resolver o conflito com a avó que, em cada cena, distanciava a possibilidade de resolução. 
Figura 14 - Cena: Oprimido Rejeitado.

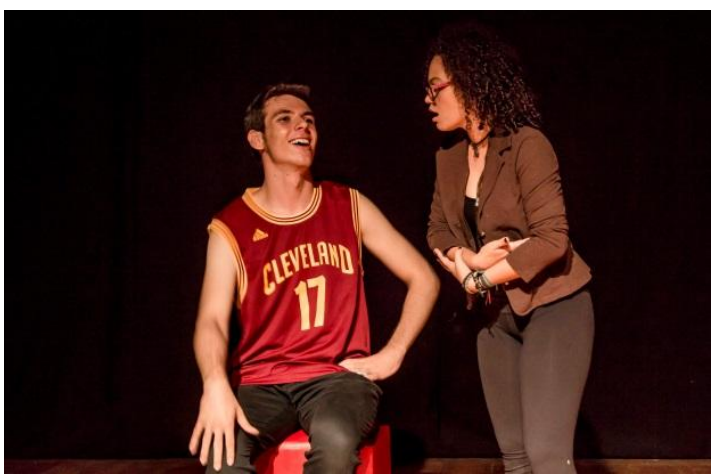

Foto 50

Figura 15 - Oprimido Expulso.

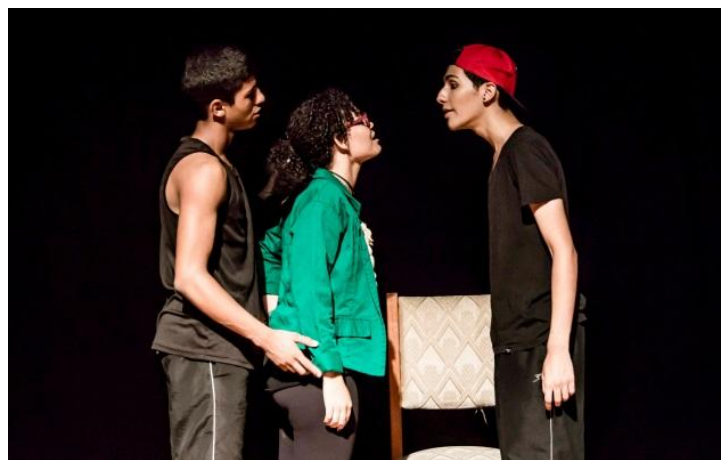

Foto 52

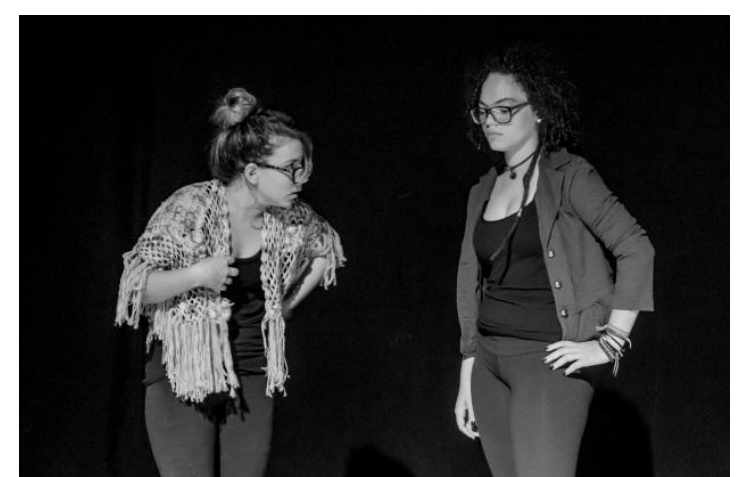

Foto 51

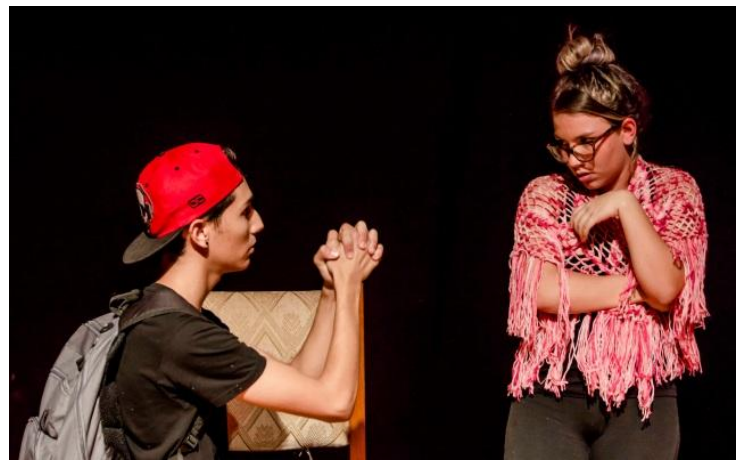

Foto53

Fotografias de Sartory - Arquivo da Autora

O momento escolhido para a intervenção da plateia deu-se quando, após uma explanação da opressora em se justificar porque não tem uma relação saudável com o neto, e que não o deseja residindo com ela, o obriga a comer o pão amassado e jogado no chão. Ela impõe a condição de: - “Ou come o pão, ou rua!” - a simbologia dessa cena reflete a submissão imposta pela avó em controlá-lo, fazê-lo de empregado diante da situação de dependência do neto, tanto econômica quanto socialmente.

Nesse momento, a cena congela e eu entro para indagar a plateia se essa situação existe, se é passível de mudanças e se tem alguém que poderia modificá-la se colocando no lugar do oprimido/neto. Esse momento do fórum é um debate realizado cenicamente, isto é, a fala do espectador é acompanhada da interpretação, do ato de agir no lugar de alguém se colocar no lugar do outro. Se for por meio do teatro que discutimos determinado conflito, será por meio dele que tentaremos resolver a situação imposta. Para Pupo: 
Privilegiamos a emergência de uma ficção; mediante a proposta precisa e direta dos meios oferecidos pelo teatro, tais como texto, espaço, personagens, o que se tinha em vista era antes de mais nada a formulação de um discurso dramático pelo grupo (2005, p. 27).

E, no nosso caso, esse discurso tinha como base a história deles. A ficção foi empoderada das versões verídicas de um período não muito longínquo, o qual serviu de base para eles terem chegado até aquele momento. Muito do que foi vivenciado quando crianças se refletiu nos adolescentes que se tornaram. Todos tinham um discurso, ainda instável, mas em formação.

Quando foi a minha vez de contar a minha historia, todos se emocionaram, talvez por eu ter sido abandonado pela minha mãe biológica aos oito meses de idade, ter passado anos vivendo com famílias diferentes e tendo que aguentar diversos abusos psicológicos horríveis para uma criança. Talvez pelo fato de que quando finalmente eu encontrei uma família, ela se desfez e aí novos problemas surgiram para um adolescente que já vinha com uma história de vida pesada (T. N., 17 anos).

Esse discurso teve sua representatividade na Cena-Fórum escolhida - fruto da votação perante outras que, por não terem sido contempladas como a cena enigmática do espetáculo, foi inserida no roteiro servindo de alicerce para se chegar à cena escolhida para o debate/fórum com a plateia. Realizei algumas mudanças para que, esteticamente, ela pudesse se tornar propícia ao que se espera de um Teatro-Fórum, afirmando a finalidade desse tipo de teatralidade, ao causar indignação na plateia diante da opressão imposta - do opressor para com o oprimido -, de modo que o público queira entrar no lugar dele e proponha resoluções ao problema encenado.

Questiono, inclusive, essa forma 'clara e objetiva' diante de um problema encenado, pois vários deles acarretam subjetividades e entrelinhas que às vezes nem o oprimido consegue ter a real dimensão do que o oprime, ou seja, do que o impede resolver aquela situação de opressão. O que é encenado vai além de um conflito social, perpassa por meandros subjetivos e psicológicos que reforçam condutas de comportamentos que geram opressão. Assim, “(...) essa invasão é uma transgressão simbólica. Simbólica de todas as transgressões que teremos que fazer para que nos libertemos de nossas opressões" (BOAL, 2003, p. 38). 
A exemplo das opressões abordadas nesse espetáculo, segundo a perspectiva de um dos adolescentes: "Estava nítido no grupo essa energia de exaltação para apresentar sobre um tema tão forte e relevante para gente, o que os acontecimentos da nossa infância podem influenciar nas nossas vidas e na dos outros” (P. A., 17 anos).

A decisão agora cabia ao neto: continuar sendo humilhado e feito de empregado por essa avó ou dar uma reviravolta em sua vida, mesmo diante do obstáculo - ter 17 anos, não trabalhar, logo, não ter condições de se sustentar. Perante esse confronto com o opressor, a pergunta se lança à plateia: "O que você faria se estivesse vivenciando uma situação semelhante à desse neto?" (Foto 54, 55, 56 e 57).

O fórum começou com a premissa de ser debatido cenicamente.

Figura 16-O Confronto

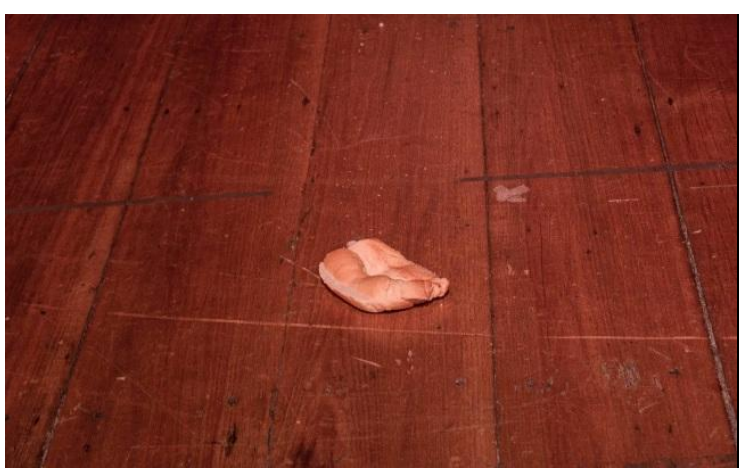

Foto 54

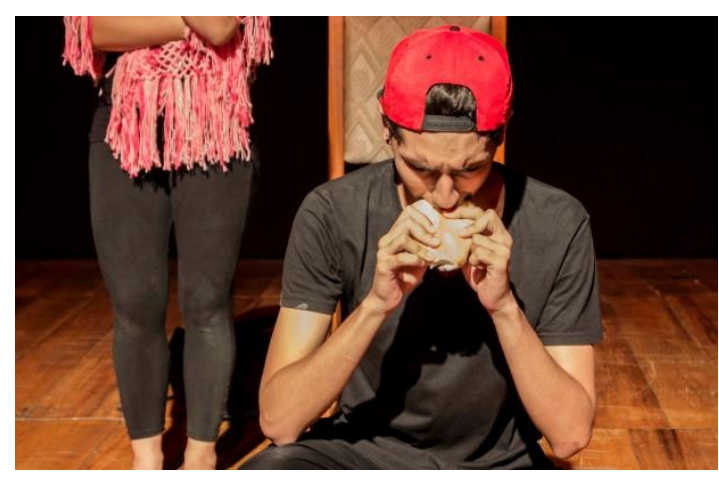

Foto 55

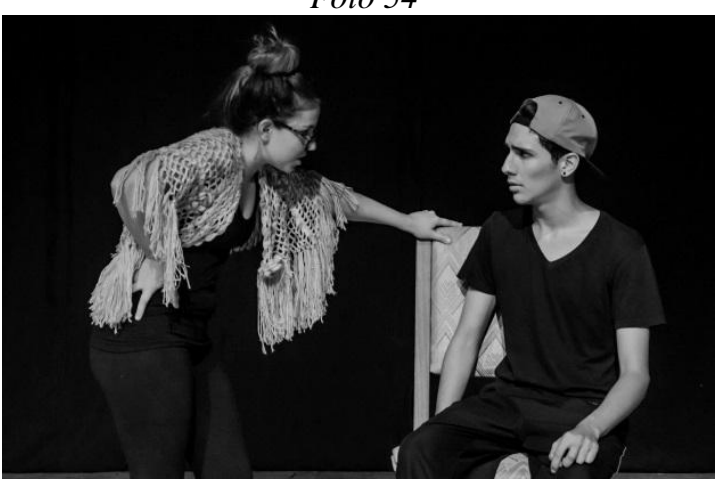

Foto 56

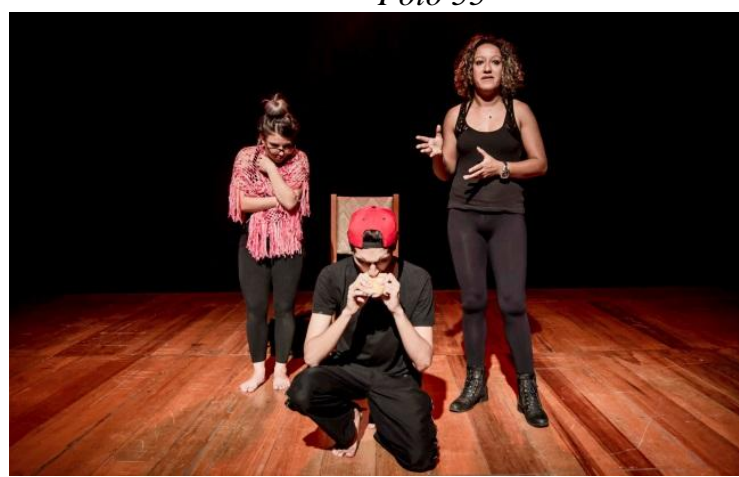

Foto 57

Fotografias de Sartory - Arquivo da Autora

\section{2 - AS INTERVENÇÕES NO ESPETÁCULO TRANSIÇÕES DE IMPACTO}

Na primeira intervenção (foto 58 e 59), um espect-ator questionou a avó por que ela o tratava dessa maneira, sendo que ele era vítima dessa situação, uma vez que sua mãe nunca o desejou e sempre fez questão de maltratá-lo, acusando-o de ter perdido a 
juventude para cuidar dele. A avó, por sua vez, afirmava dizendo que ele sempre foi uma pedra no sapato dela e da mãe, e que ele era tão ruim que sobreviveu a três tentativas de aborto. Nesse momento, a personagem opressora repete a mesma ameaça que havia feito ao ator - que interpretou oprimido - de obrigá-lo a comer o pão, que se encontrava no chão amassado, ou rua, expulsando-o de casa.

Figura 16-Cena-Fórum: O Confronto. I Intervenção.

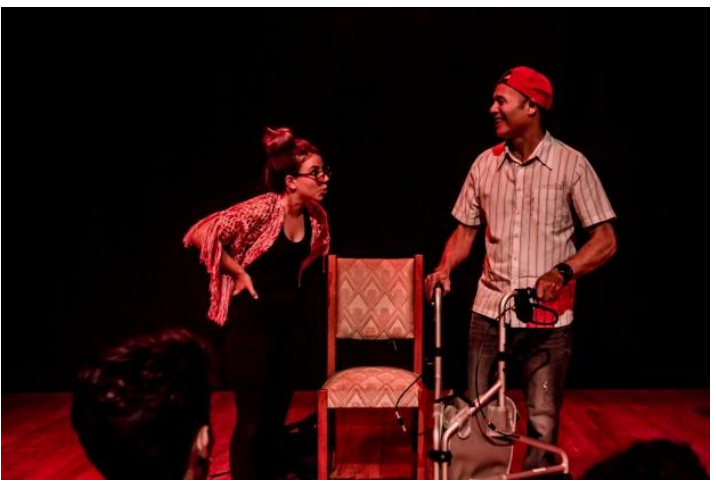

Foto 58

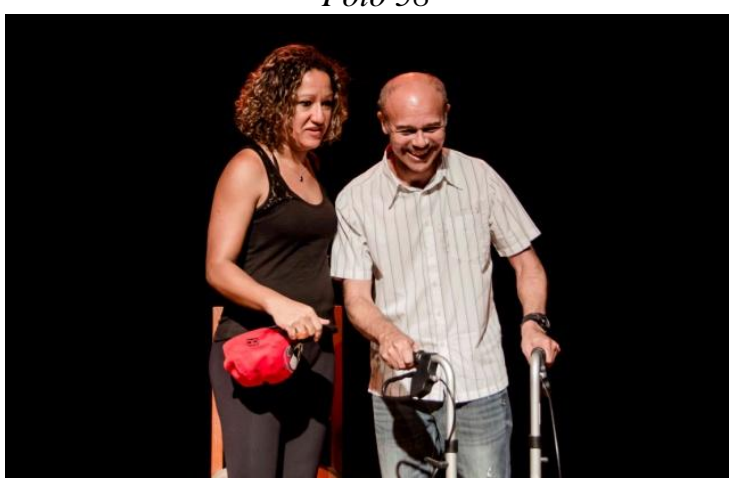

Foto 60

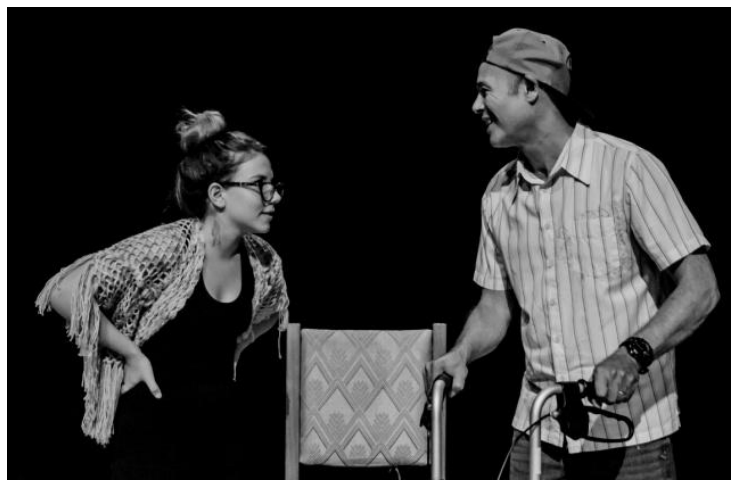

Foto 59

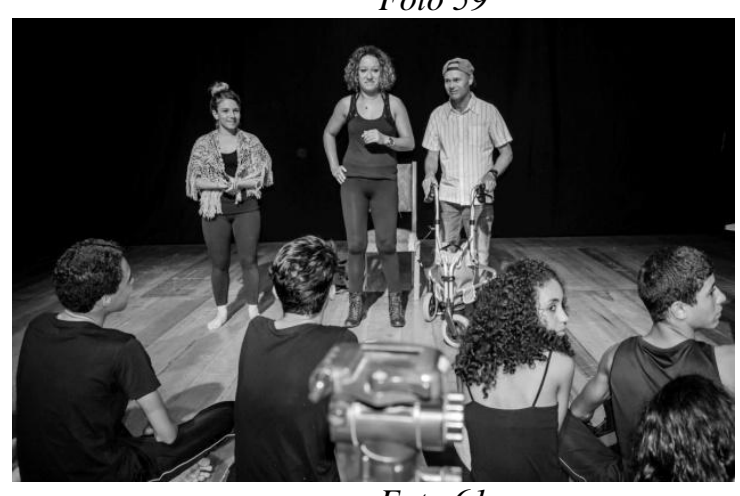

Foto 61

Fotografias de Sartory - Arquivo da Autora

O espect-ator (foto 60) optou por ir embora, mesmo sem ter para onde ir e nem como se sustentar, alegando que preferia a opção de morar na rua e, ocasionalmente, ser humilhado por estranhos, do que continuar naquela casa sendo humilhado e castigado pela avó materna. O público o aplaudiu com entusiasmo e alguns comentaram que ele tinha agido corretamente. Eu, com a função de questionar a plateia (foto 61), perguntei se essa foi a solução mais apropriada, visto que o oprimido não tinha condições, naquele momento, de se manter. Diante de meu questionamento, eles refletiram e concluíram que, de fato, aquela não tinha sido a melhor solução.

Com essa intervenção e com a discussão provocada diante dos argumentos postos em cena, foi possível analisar que o Curinga assume a função de informar à plateia sobre o conflito colocado em cena, além de auxiliar a atuação dos sujeitos no 
contexto social, mobilizando-os, assim, a atuarem com o propósito de desconstruir estruturas de poder e de opressão existentes nas relações sociais.

A segunda intervenção veio da necessidade da espect-atriz em argumentar que, apesar de todas as diferenças e dificuldades que a avó havia enfrentado ao assumir uma filha que tinha engravidado na adolescência, havia laços de sangue entre eles que deveriam ser respeitados (foto 54). E que, por mais que ela (como oprimida) havia sofrido vários tipos de humilhação, ela não conseguia ter raiva da avó e, sim, o sentimento que a dominava era de amor. A ação da oprimida foi de pegar o pão (foto 55), colocá-lo em cima da mesa e surpreender a avó com um abraço dizendo que a amava e que, juntas, poderiam construir uma nova relação e tentar viver em harmonia.

Figura 17 - Cena-Fórum: O Confronto. II Intervenção.

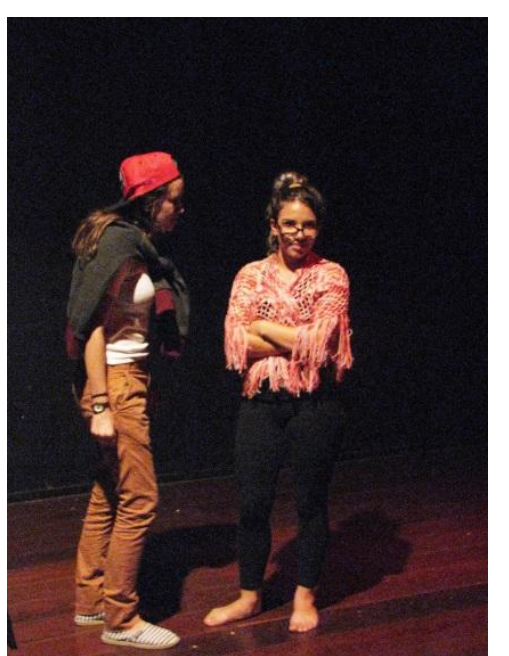

Foto 62

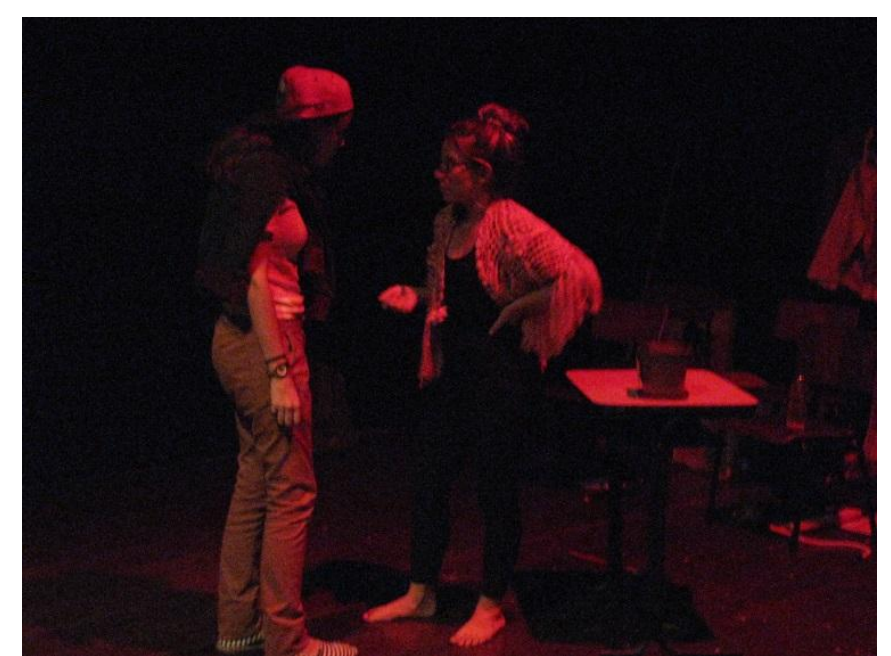

Foto 63

Fotografias de Hugo de Freitas - Arquivo da Autora

Diante desse ato simples, fraterno e inesperado, a avó cedeu emocionada ao apelo da neta; deixando-a ficar e retirando a ação de obrigá-la a consumar o símbolo da opressão. O público a aplaudiu de pé diante dos seus argumentos encenados, de como suas ações/palavras surpreenderam a todos, principalmente, a avó, e, por fim, de como atuar nessa cena a sensibilizou (foto 62). Alguns comentários se sobressaíram ao evidenciar que o amor pode tudo. Nesse momento, ressaltei (foto 63) que, às vezes, a solução de alguns problemas está em atitudes simples, em demonstrações de afeto e aberturas ao diálogo. 


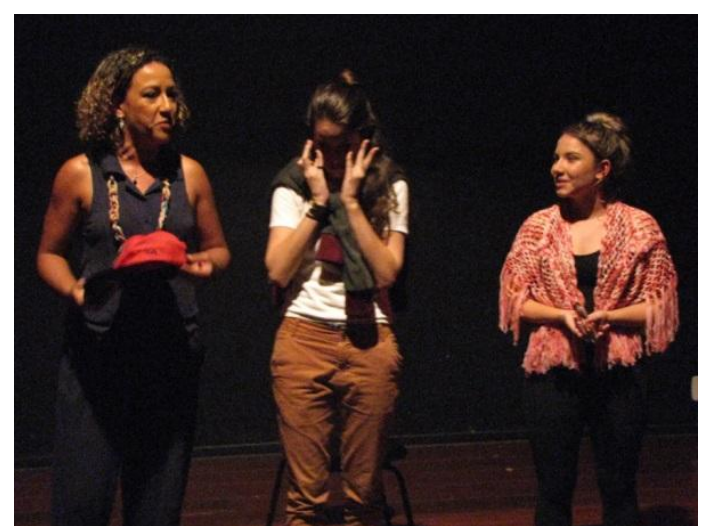

Foto 62

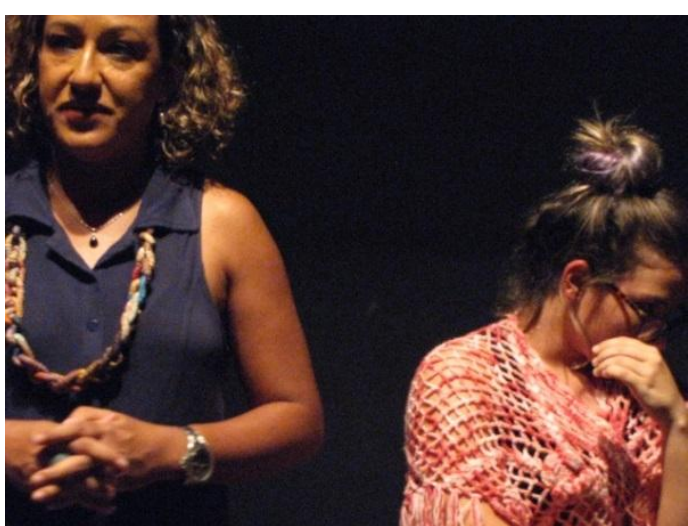

Foto 63

Fotografias de Hugo de Freitas - Arquivo da Autora

Canda salienta que:

Cabe aqui pontuar que o curinga deve estar sempre atento a todas as reflexões propostas pelo público; deve retomála, valorizando a fala dos espect-atores, mas também os provocando à intervenção na cena. Os resultados das intervenções dependem, em certa medida, do potencial de mobilização do curinga (2013, p. 132).

A respeito do que Canda enfatiza sobre o papel do Curinga em um espetáculo Fórum, aquelas sugestões que não suscitam mudanças por parte do opressor, tão pouco uma possibilidade de resolução a partir do olhar atento e questionador da plateia, devem também ser frisadas no intuito da percepção de sua ineficácia quanto à proposta de resolução. Ou seja, algumas sugestões encenadas devem servir de alerta - neste caso é interessante que o Curinga ressalte - em seu papel de intermediador este tipo de ocorrência -, uma postura que não levará à remediação do conflito teatralizado e, dependendo da proposta, cria outro problema acumulando o já ressaltado em cena.

Para ilustrar essa observação, destaco uma intervenção, a terceira, em que a jovem argumentou à avó (opressora) que não considerava suas humilhações e demonstrou, ao despedaçar o pão amassado e no chão, que ela teria que aturá-la por ser sua neta e menor de idade (fotos 64 e 65). Disse ainda que daria motivos para ela odiá-la cada vez mais porque agora ela iria se rebelar, tratá-la como é tratada (foto 66). Logo após sua fala, a jovem me entregou o boné vermelho - símbolo do oprimido - como sinal que sua participação havia acabado, tirando o direito da avó de se manifestar diante de sua reação e suas ponderações. 
Figura 18 - Cena-Fórum: O Confronto. III Intervenção.

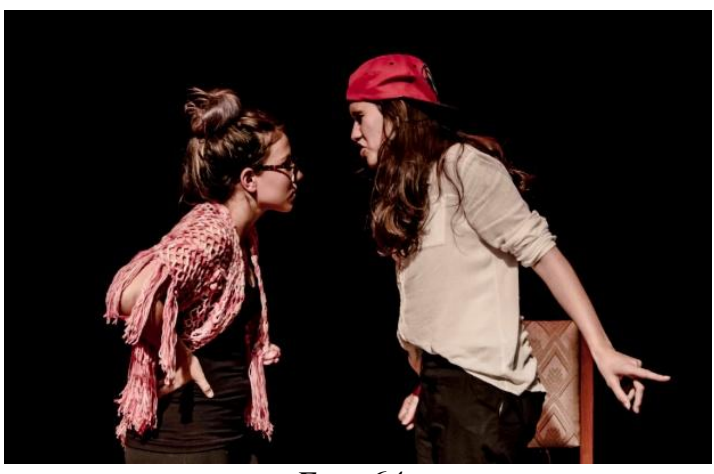

Foto 64

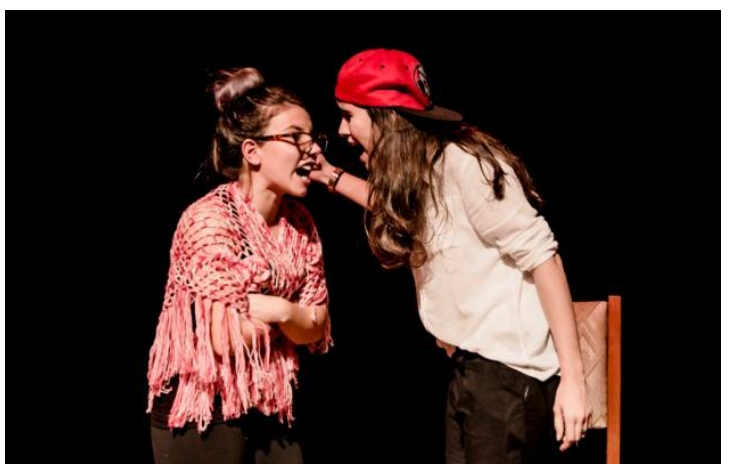

Foto 66

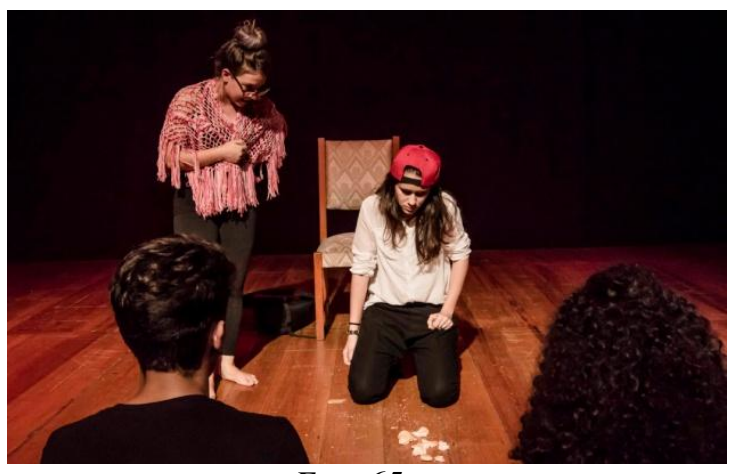

Foto 65

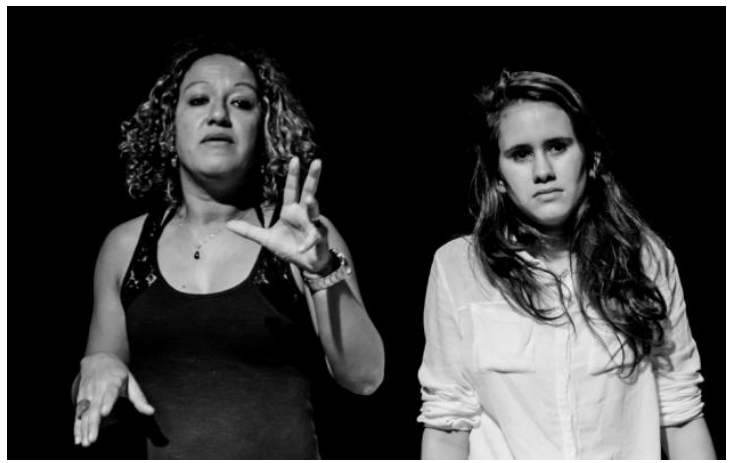

Foto 67

Fotografias de Sartory - Arquivo da Autora

O público a aplaudiu fervorosamente, uns falaram que ela estava certa em tratar a avó do mesmo modo como era tratada. Este foi o momento em que questionei se essa atitude era capaz de resolver o problema (foto 67). Ainda ressaltei se, na tentativa de resolução, acabamos por criar mais obstáculos ao fazer o mesmo jogo do opressor - o de medir forças e exercer poder de forma deturpada. Será que a proposta da jovem não seria a renúncia do desejo? O conflito não foi solucionado, pois ela admitiu ter o mesmo tipo de atitude da avó. Nesse caso:

Por ser o Teatro-fórum um espaço educativo e democrático, a solução da desistência da luta pode aparecer como uma atitude gloriosa e criativa do espectator, mas pode representar a desistência do desejo, cujas consequências seriam sofridas pelo oprimido (CANDA, 2013, p.132).

Reforcei a crítica em relação ao público, a respeito do aplauso fervoroso diante da atitude da espect-atriz que só reforçou o posicionamento da opressora agindo da mesma maneira. O público, de fato, está atento as tomadas de decisão e propostas de 
mudanças em relação ao problema encenado? Ou ele se acomoda mediante possibilidade de ser um mero contemplador da obra artística? No fórum não cabe aplausos absortos, sinônimo de il gran finale, como se estivesse uma distância entre palco e plateia que causasse passividade por parte do espectador. Pelo contrário, esperase da plateia reações que favoreçam a discussão/reflexão do que se está sendo proposto e, caso o espect-ator reforce situações de opressão e/ou desista de seu desejo, o público deve encorajá-lo e incentivá-lo a lutar pelos seus direitos criando alternativas de solucionar a opressão encenada.

Ao fazer parte de um espetáculo-fórum, mais precisamente quando o espect-ator participa da cena-fórum, esta contribui para a materialização de suas ideias, mesmo de modo fictício. Esse recurso favorece a ampliação da reflexão da plateia de um modo geral. Assim, é possível afirmar que esse é um espaço de formação estética e política, pois oportuniza o ato de experimentar soluções advindas do público, gerando, consequentemente, a troca de informações, reflexões e perspectivas.

Como observa Pareyson (1997, p. 224):

(...) as interpretações são múltiplas, tantas quantas as pessoas que se aproximam de uma determinada obra, e até mais, se pensarmos nas mudanças a que, no curso de sua vida, uma mesma pessoa é levada, sob o estímulo de novas circunstâncias e de novos pontos de vista.

E Canda (2013, p. 133) acrescenta:

\begin{abstract}
No processo de fruição de um espetáculo-fórum, este campo de interpretações infinitas pode ampliar-se ainda mais, pois os sujeitos, além de efetuarem leituras da obra, são convidados a complementarem o sentido do espetáculo no lugar do criador. No Teatro do Oprimido, a possibilidade de criação cênica pelo espectador é conciliada com a ideia de que a obra de arte não é um produto pronto e acabado a ser apreciado pela plateia.
\end{abstract}

A respeito da vivência de um processo como este, que em sua finalização pode ser considerada uma obra artística, há o encontro de aprendizagens e experiências sobre o viés de duas perspectivas: do ator e do espectador. O primeiro aprimora-se no ofício de se manifestar artisticamente através da arte de interpretar, e o segundo, assumindo 
também a função de espect-ator, aviva sua experiência como apreciador, leitor da obra encenada e, principalmente, um agente que intervém e gera mudanças.

E para uma opressora? Também tive que compreender o outro. Entender a história da personagem e os seus motivos de estar ali, afinal de contas, uma história nunca tem apenas um lado (D. A., 17 anos).

Essas mudanças evidenciaram-se diante das intervenções dos espect-atores no espetáculo Transições de Impacto. Uns buscaram o afeto, outros confrontaram a avó e disseram que tentariam uma saída estando junto dela, e outros ainda preferiram confrontá-la e ter a mesma atitude opressora. A Cena-Fórum é um espaço no qual os pontos de vista se manifestam, intrínsecos na singularidade de cada interpretação, ou seja, a ação e reação traduzem as emoções que ali se manifestam, criando a liberdade de se colocar e de se tornar um transformador da situação encenada. Ampliam-se, portanto, as experiências estética e política, assegurando, por fim, um aspecto pedagógico do Teatro-Fórum na formação do espectador. Como denota Flávio Desgranges em seu livro A pedagogia do espectador (2003, p. 37):

Educar o espectador para que não se contente em ser apenas o receptáculo de um discurso que lhe proponha um silêncio passivo. A formação do olhar e a aquisição de instrumentos linguísticos capacitam o espectador para o diálogo que se estabelece nas salas de espetáculo, além de lhe fornecer instrumentos para enfrentar o duelo que se trava no dia-a-dia.

Desgranges enfatiza a formação do espectador em relação a um comprometimento pedagógico no que se refere ao acesso e à assiduidade do público nas salas de teatro. Portanto, a análise dessa oficina e, consequentemente, do seu resultado com o espetáculo-fórum Transições de Impacto, atribui ao Teatro do Oprimido um espaço cuja metodologia se aplica às questões sociais auxiliando os participantes na formação estética, diante do acesso à linguagem teatral como um meio de discutir situações diferenciadas de opressão social.

O fenômeno artístico proporciona momentos que suscitam provocações política e estética, possibilitando a construção de autonomia por parte do sujeito, sendo 
instigada também por uma perspectiva pedagógica desse encontro com as artes. Desgranges defende a linguagem teatral e seus elementos de composição como uma ferramenta capaz de educar por meio da vivência, experiência e participação - esta na relação que se estabelece entre o palco e a plateia. Assim,

A capacitação do público para participar ativamente do evento teatral está fundamentalmente vinculada à proposição artística que lhe é dirigida, e se estabelece também pela maneira como o artista trabalha e compreende o ponto de intersecção entre a cena e a sala. (DESGRANGES, 2003, p. 28).

A obra artística possibilita o diálogo a partir das interpretações diferenciadas que ela propõe, ao mesmo tempo que permite trocas de aprendizagens e experiências. As funções estabelecidas em seu âmbito adquirem maior singularidade por favorecer o posicionamento de quem as vivencia. Nesta pesquisa, portanto, analiso três posições que se fundem na tentativa de resolução frente ao conflito encenado:

- o papel do ator, ao interpretar a obra e revelar o conflito ao espectador;

- o papel do espectador, ao apreciar a obra, ler os elementos que compõem a linguagem da encenação e dialogar com o que está sendo evidenciado em cena;

- o papel do espect-ator, ao intervir na obra modificando-a, posicionando-se e contribuindo para diferentes desfechos.

Desgranges (2003), ao perceber que conflitos inerentes da relação do sujeito em sociedade podem ser contemplados por um viés artístico, amplia e (re)significa a linguagem cênica como veículo de reflexão e mudança de atitude. Como o mesmo analisa em conformidade com o pensamento de Boal (2006, p. 09): "A experiência artística se coloca, deste modo, como reveladora, ou transformadora, possibilitando: a revisão crítica do passado; a modificação do presente; e a projeção de um novo futuro".

Essa constatação de Boal vai de encontro com a reflexão de um dos adolescentes ao término da oficina de Teatro do Oprimido: 
Escolhemos falar sobre assuntos referentes à nossa infância. Silvia sempre esteve muito aberta ao que a gente gostaria de falar, o que foi ótimo porque nos proporcionou momentos de reflexão que normalmente não temos a oportunidade de dialogar sobre. E está ai a magia do Teatro do Oprimido, o momento de dar voz a aqueles que são oprimidos e a oportunidade deles dialogarem com pessoas que passaram por coisas parecidas (P. A., 17 anos).

Mais adiante, ele acrescenta:

Foi muito bom participar dessa oficina, conhecer essas pessoas e poder falar sobre esse tema. Depois do Oprieram, me considero uma pessoa diferente. O Teatro do Oprimido me fez enxergar diferente, a minha relação com as pessoas e as maneiras como eu posso me posicionar (P. A., 17 anos).

O diferencial no trabalho de Boal vai além de fazer com que o espectador se torne ativo perante a encenação, como expõe Desgranges, mas que se torne protagonista da cena uma vez que o conflito encenado precisa de sua participação direta e imediata frente à sua solução para o problema em cena. Não existe uma única solução ou a melhor, e, sim, várias soluções de acordo com a subjetividade e vivência do espect-ator. Com isso, Teatro-Fórum, como um dos componentes do Teatro do Oprimido:

(...) não deve terminar nunca, porque tudo que nela acontece deve ser extrapolado na própria vida. O Teatro do Oprimido está no limite entre a ficção e realidade: é preciso ultrapassar esse limite. E se o espetáculo começa na ficção, o objetivo é se integrar na realidade, na vida (BOAL, 2006, p. 347).

Um dos pontos se refere à aplicação do Teatro do Oprimido no âmbito escolar, ainda que esse tema não seja aprofundado nessa pesquisa, prima, em meu entendimento, pela interação entre sujeito e objeto de aprendizagem, em uma troca de vivências e produção de conhecimentos da relação estabelecida entre professor e alunos. O TeatroFórum, em específico, permite que o cotidiano escolar, por exemplo, seja problematizado, de modo a contribuir para a formação de valores e de condutas conscientes para as relações escolares e o convívio em sociedade. "Teatro não é didático 
no velho sentido da palavra e do estilo, mas pedagógico no sentido de aprendizado coletivo" (BOAL, 2002, p. 22).

A partir da pesquisa de Carmen Lúcia Abadie Biasoli - A formação do professor de arte: do ensaio... a encenação (1999) -, percebo que a busca de cada indivíduo em ser uma pessoa completa perpassa pelo entendimento de dois movimentos: o cultural e o educativo. O conhecimento é adquirido por meio de um interlocutor, no processo de alguém que fala e alguém que escuta. Em uma instituição escolar, esse "alguém" recebe a denominação de professor e de aluno respectivamente. Por meio do conhecimento, estamos formando, antes de tudo, um sujeito, e o ideal é que nessa formação estejam imbuídas a "arte" do pensar, do refletir e do criticar.

Uma das formas de educar provém do conhecimento artístico que está vinculado à compreensão filosófica do mundo, ou seja, perceber o homem como sujeito, como ser cultural e social, aproximando, assim, a arte da educação. Temos como o interlocutor desses dois vieses, para a formação do sujeito, o professor de Arte. Ele é o responsável por fazer de sua prática de ensino de Arte condições para que os alunos entendam o conteúdo já existente, mas que aprendam a associá-lo à prática, à vivência, a novas formas de construção e produção de conhecimentos.

A educação não acontece somente no ambiente escolar, mas, sobretudo, na junção entre o conhecimento sistematizado (orientado pelo currículo escolar) e o conhecimento vivenciado (através do cotidiano). A escola de hoje, na era da contemporaneidade, tem como desafio aliar esses dois tipos de saberes e formar, por conseguinte, um cidadão crítico, que irá relacionar a teoria com a prática e, principalmente, associar o que se aprende em sala de aula ao seu cotidiano.

O contato com a linguagem teatral proporciona criar e reviver situações, a fim de nos posicionarmos perante algo ou alguém, ou seja, o ato de representar coloca em questão o seu mundo e o mundo vivido pela sua personagem e, portanto, implica em um aprendizado humano, um olhar diferenciado e distanciado da realidade que proporciona diferentes possibilidades de compreendê-la. O importante é sabermos o que fazer e como fazer (ação). Segundo Tiche Vianna e Márcia Strazzacappa em seu artigo sobre Teatro na Educação: reinventando mundos (2001, p.121), sinalizam que "Pela arte de representar o outro, podemos refletir sobre quem somos e sobre o papel que representamos hoje neste nosso mundo". 
Portanto, o estímulo à criação por intermédio da imaginação através de um processo lúdico abordado no teatro proporciona ao aluno sensibilidade, perspicácia, reflexão e crítica para enfrentar as benevolências e dificuldades dessa sociedade contemporânea. Desse modo, a arte é a máxima expressão pessoal e cultural desse sujeito, por despertar a imaginação, percepção, criatividade, proliferação de suas ideias, crenças e tradições. Permite, concomitantemente, a formação do sujeito, o conhecimento de si próprio e do lugar onde está situado.

Biasoli (1999) defende que a arte tem a função de simbolizar os valores - do espiritual ao material - que caracterizam uma sociedade. O pensamento de Biasoli está em concordância com as questões sociais, políticas e artísticas exploradas por Boal, de que a arte tem um papel fundamental na busca pela identidade cultural, pois capacita $\mathrm{o}$ sujeito “(...) a aprender e analisar a realidade do meio ambiente, inserindo-o no lugar ao qual pertence e possibilitando-lhe mudar a realidade apreendida" (BIASOLI, 1999, p. 92).

A escola tem um papel imprescindível no reconhecimento dessa 'interculturalidade'. José Carlos Libâneo, em sua pesquisa sobre Organização e gestão da escola: teoria e prática (2004), salienta a importância de reconhecer essa pluralidade cultural e saber dialogar com ela. Afinal, antes de tudo, estamos tratando das relações humanas. Os sujeitos são compostos por memórias, sentimentos, vivências, diferenças e são possuidores de uma identidade cultural própria. A partir da formação individual, forma-se o coletivo, isto é, grupos socioculturais que se juntam de acordo com afinidades e/ou necessidades. São os sujeitos que formam os grupos.

Como descreve o anseio de uma adolescente:

Eu sempre quis ser professora. Mas sempre quis dar uma aula diferente, ensinar um conteúdo diferente do comum para formar cidadãos e não somente indivíduos letrados. Vi no teatro essa oportunidade. Mas, especificamente no Teatro do Oprimido, vi uma necessidade. Necessidade esta de levar a força e a compreensão de mundo aos jovens da sociedade confusa em que nos encontramos. Digo exclusivamente aos jovens porque nós construiremos o futuro e não há futuro sem compreensão do outro, sem se colocar no lugar do outro (D. A., 17 anos). 
A todo instante, o sujeito tende a necessitar, a perceber e a entender seus desejos, angústias, metas que, em síntese, resultam na busca por si mesmo, por se autoconhecer. Isso permitirá, logo adiante, conhecer também o(s) outro(s) e conviver com esse(s) outro(s). Essa aliança começa a ser estabelecida quando o sujeito se socializa. Boal considera que:

O nosso desejo é o de melhor conhecer o mundo que habitamos, para que possamos transformá-lo da melhor maneira. O teatro é uma forma de conhecimento e deve ser também um meio de transformar a sociedade. Pode nos ajudar a construir um futuro, em vez de mansamente esperarmos por ele (BOAL, 2006, xi).

Na formação de cada indivíduo, a cultura pode ser definida como a coletivização de manifestações artísticas e intelectuais presentes em cada sujeito que, exteriorizada em grupo, permitem não só falar de si, de conteúdos e experiências integralizados mas, e, principalmente, ser uma voz de todos, transmitida oralmente, expressivamente em relação ao meio social do qual faz parte.

Ao elaborar o Teatro-Fórum com esses adolescentes, associando também a Estética do Oprimido por meio de um conjunto de exercícios propostos pelo arsenal do Teatro do Oprimido, abriu-se a possibilidade de que essas técnicas vivenciadas possibilitassem dar voz ao sujeito por meio da apreensão estética. Acrescento à reflexão, com a fala de um dos adolescentes que participaram da oficina:

Todo esse processo nos marcou e nos fez enxergar o mundo de outra forma. Trabalhar com o tema: abandono, infância e opressão, nos fez amadurecer bastante e a forma como o grupo tratou deste assunto foi incrível! Creio que conseguimos passar para o público boa parte do que temos para dizer e, com certeza, temos muito mais (M. B., 17 anos).

Outra adolescente acrescenta: 
Antes de fazer parte do Oprieram e conhecer o Teatro do Oprimido, minha vida era sem perspectivas, era monótona. Fazia o que meus pais achavam o que era melhor pra mim. Hoje tenho opinião, estou trilhando meu próprio caminho, a vida passou a ter um colorido diferente (C. R., 16 anos).

Com as resoluções postas em cena, dialogo com a plateia - na função de Curinga - discutindo quais foram as soluções possíveis de serem colocadas em prática. Essa mediação entre palco e espect-ator permite informar, conscientizar e, principalmente, levantar possibilidades de resoluções concretas, caso o problema encenado seja, um dia, vivenciado. Dar voz ao espect-ator nesse momento amplia sua perspectiva de transformar a realidade e as situações de opressão que o cerca.

No Teatro-Fórum, sua aplicação possibilita a diversificação, a dinamização e o fortalecimento das estratégias de ações na busca de soluções para as dificuldades advindas do convívio social. Assim, essa experiência estimulou a participação ativa e protagônica dessa camada oprimida, visando à transformação da realidade a partir do diálogo entre elas.

Ao aplicar o Teatro do Oprimido nesses grupos sociais, abre-se a possibilidade de ampliar a compreensão do trabalho teatral como processo de formação e pesquisa, e oferecer condições para que os grupos possam criar mecanismos de discutirem, por meio do Teatro-Fórum e das outras técnicas contidas no arsenal do Teatro do Oprimido, resoluções de conflitos, além de informações acerca da relação com a sociedade.

Junto a um colega, levamos uma minioficina para a nossa escola. Uma vez por semana fizemos alguns jogos e improvisos bem simples com alguns colegas nossos de Segundos e Terceiros anos, que resultou na mesma garra que nós sentimos no começo do Oprieram. Percebemos que essa reação não pertencia só a nós. Ao final dessa minioficina, perguntamos o que os alunos acharam. Além de muitos elogios uma coisa era comum: todos queriam mais. Bem ali, naquele momento, tive a certeza que essa "matéria" poderia fazer a diferença em um cotidiano totalmente chato, onde o opressor, entre muitos outros, é o vestibular que te lembram todos os dias. É a carreira que tem que dar dinheiro. É o dever de ser bom em todas as matérias. É ser quem os outros querem que você seja. Nós jovens, na escola e em casa, somos a dúvida. No teatro, apenas somos. No teatro do Oprimido somos a resposta. É, eu também aprendi a admirar o Boal tanto quanto a Silvia (D. A., 17 anos). 
O relato dessa adolescente, em destaque, evidencia que o protagonismo foi desenvolvido durante esse processo. Sua compreensão aliada a sensibilidade em ir além dos objetivos dos jogos, das criações das cenas e dos debates improvisados cenicamente, principalmente aqueles diante da entrada do público na Cena-Fórum, demonstra que a luta por um espaço que possa discutir situações de opressão não é uma utopia.

O Teatro do Oprimido propõe que o sujeito se coloque, se sinta livre para se expor, para rever valores e condutas, se sinta capaz de modificar aquilo que incomoda e que tenha acesso a informações que contribua para sua apreciação e, porque não, limites diante da relações estabelecidas socialmente.

Nesse jogo lúdico em que o oprimido se liberta e o opressor "justifica suas ações", mas também pode rever condutas de pensamentos e ações, é compartilhado um arsenal em que qualquer um que tenha contato pode se apropriar. Esses adolescentes se apropriaram dessa experiência. Identificaram-se com essa metodologia a ponto de experimentá-la com seus colegas também adolescentes e ter a experiência de observar como cada um responde aos estímulos oferecidos pelo Teatro do Oprimido.

Foi possível que esses adolescentes questionassem, com mais propriedade, os opressores que tendem a criar regras de convivências, receitas de felicidade, sucesso profissionais perante a insistência da obrigatoriedade do vestibular, por exemplo. Para a maioria, a experiência com a oficina ajudou na escolha da profissão, o que motivou a estabelecer uma relação mais amigável com esse único modo de ingressar no ensino superior ${ }^{5}$.

O Teatro-Fórum pode ser um meio de trabalhar ações protagônicas por meio da apreensão estética, de modo que isso potencialize a discussão vivida em cena e permita ações protagônicas tanto de quem vive o processo, como de quem assiste. Portanto, o desenvolvimento da capacidade artística e das habilidades provenientes com a prática na oficina possibilitou aos adolescentes a consciência de sua importância no desenvolvimento social e na promoção da convivência pacífica. Sendo assim, o adolescente sensibilizado e estimulado a pensar a realidade que vivencia se torna, ao expor sua visão de mundo, um potencial agente de mudança.

$5 \quad$ No término do ano de 2015, ao prestarem o Vestibular, dos oito que passaram por esse processo, seis conseguiram entrar em Instituições de Ensino Superior: uma em Matemática - UnB (Universidade de Brasília), três em Artes Cênicas - UnB e dois em Artes Cênicas - FADM (Faculdade de Artes Dulcina de Moraes). 


\section{CONSIDERAÇÕES FINAIS}

O Teatro do Oprimido busca, por meio da apreensão estética, dar voz ao sujeito ao colocá-lo em contato com a linguagem teatral e, através dela, poder se manifestar, se autoconhecer, se socializar e refletir sobre si e sobre viver em sociedade. A linguagem teatral é abordada pelo viés de um conjunto de exercícios e de técnicas denominadas de arsenal do Teatro do Oprimido, que possibilita um espaço de conceituar e vivenciar conflitos sob a ótica de dois personagens-chave - o opressor e o oprimido. São as relações de poder sendo identificadas e, se possível, postas em debate.

Esta pesquisa foi divida em duas partes. Na primeira parte descrevi e analisei o processo metodológico do Teatro do Oprimido com adolescentes de duas escolas públicas do Distrito Federal. Esse processo resultou no aprofundamento do TeatroFórum e, como resultado, a criação do espetáculo Transições de Impacto. Na segunda parte, analisei as intervenções do público no referido espetáculo-fórum. Realizei um recorte a respeito do arsenal do Teatro do Oprimido e como algumas técnicas foram se modificando e sendo reelaboradas, no processo de descoberta do teatrólogo Augusto Boal, ao utilizar o teatro como instrumento político.

As relações humanas podem ser criticadas, discutidas, argumentadas; a partir de um jogo lúdico, no qual a problemática de uma situação real é teatralmente posta em cena, a fim de causar reações imediatas por parte do espectador. Essas reações, além de impulsionar a reflexão, gerarão tomadas de atitudes frente às situações de opressão colocadas em cena e na vida real.

Ao analisar essa experiência empírica com os adolescentes, abre-se o precedente do Teatro-Fórum ser um espaço no qual o sujeito observa, intervém e analisa, com o grupo, a sua ação. Nesse contexto, o sujeito desenvolve sua visão estética e reflexão política no que tange as relações de poder. Contudo, concluo que as experiências teatrais vivenciadas são absorvidas e apoderadas em um processo de aprendizagem individual, ou seja, cada um irá absorver e apropriar-se dessa formação de maneiras e intensidades diferenciadas.

Diante de minha trajetória de dez anos como Multiplicadora do Teatro do Oprimido, sinto-me privilegiada pela oportunidade de aplicar essa técnica em diferentes 
grupos sociais possuidores de tantas singularidades e de vozes que carecem de oportunidade para se manifestar. Guardo tantas narrativas em minhas lembranças e em meus escritos, onde um tipo de pesquisa como esta me proporciona desafios em descrevê-las acompanhadas de escopo teórico que me auxilia na reflexão e análise desse considerável percurso.

O grupo Oprieram, que protagonizou esta prática pedagógica, consolidou mais uma vez a eficácia do Teatro do Oprimido. Todo seu aparato metodológico permitiu que cada participante tivesse acesso à experiência estética, principalmente, quando vivenciaram o Teatro-Fórum - este por abranger, por meio de uma obra artística, uma produção de diferentes sentidos.

Esse processo metodológico perpassa pelos jogos teatrais, por cada técnica que compõe o arsenal e finaliza na Estética do Oprimido. Porém, nesta pesquisa, foi dada ênfase na técnica - Teatro-Fórum, por entender que o debate encenado proporciona o desenvolvimento de uma dimensão política, ao inserir o sujeito frente a uma realidade teatralizada. Isso permite que ele intervenha e procure soluções específicas diante de opressões entre os personagens.

O espetáculo Transições de Impacto é o resultado das vozes desses adolescentes que optaram por encenar situações que vivenciaram na infância, assim como de relatos que ouviram de seus amigos próximos, no qual eram indefesos diante das redes de opressões impostas. Hoje, mais fortalecidos, aprenderem a se defender. O gigante se tornou, em alguns casos, menor do que eles ou, até mesmo, indefeso. Os limites foram restabelecidos. Para alguns, a convivência trouxe perdão e tolerância. Para outros, a experiência no fórum trouxe possibilidade de mudança, ainda dá tempo de construir outra relação.

Essa transição, no qual todos passamos, gera impactos diferenciados. E, livre de julgá-los, nos ensina que podemos modificar o que nos incomoda, podemos perpetuar o que nos agrada. Assim, o protagonismo permite que possamos nos fortalecer diante dos desafios presentes no cotidiano. 


\section{REFERÊNCIAS}

AITO - Associação Internacional de Teatro do Oprimido. Declaração de Princípios,

2012. http://www.theatreoftheopressed.org/en/index.php?nodeID=141. Acesso em $02 / 10 / 2015$.

ARAÚJO, Alcione. Sei que vou continuar - Augusto Boal. In Revista de Teatro Sociedade Brasileira de Autores (SBAT), 2011.

BEZERRA, Antônia Pereira. O Teatro do Oprimido e a Noção de Espectador - Ator: Pessoa e Personagem. In: Anais do I Congresso Brasileiro de Pesquisa e PósGraduação em Artes Cênicas. ABRACE, 1999, pp. 499 - 509.

BIASOLI, Carmen Lúcia Abadie. A formação do professor de arte: do ensaio... a encenação. In: O enredo constitui a ação da encenação. Campinas, SP: Papirus, 1999.

BOAL, Augusto. A Estética do Oprimido. Rio de Janeiro: Garamond, 2009. . Hamlet e o Filho do Padeiro. Rio de Janeiro: Record, 2000. . Jogos para atores e não-atores. Rio de Janeiro: Civilização Brasileira, 2006.

. O Arco Íris do Desejo. Rio de Janeiro: Civilização Brasileira, 2002. . O teatro como arte marcial. Rio de Janeiro: Garamond, 2003. . STOP: C'est Magique! Rio de Janeiro: Civilização Brasileira, 1980.

. Teatro do Oprimido e outras poéticas políticas. Rio de Janeiro: Civilização Brasileira, 2005. . Teatro Legislativo. Rio de Janeiro: Civilização Brasileira, 1996. . Técnicas Latino Americanas de Teatro-Popular. São Paulo: Hucitec, 1988.

Educação, Pedagogia e Cultura. In. Metaxis - A Revista do Teatro do Oprimido. Periódico institucional do CTO-Rio. № 3 - Rio de Janeiro, 2007.

Projeto Prometeu. In. Metaxis - A Revista do Teatro do Oprimido. Periódico institucional do CTO-Rio. No 3 - Rio de Janeiro, 2007. 
BOAL, Julian. Opressão. In: Metaxis - A revista do Teatro do Oprimido. Periódico institucional do CTO-Rio. N 6 - Rio de Janeiro, 2010.

BÔAS, Rafael Litvin Villas. MST conta Boal: do diálogo das Ligas Camponesas com o Teatro de Arena à parceria do Centro do Teatro do Oprimido com o MST. Revista do Instituto de Estudos Brasileiros, Brasil, n. 57, p. 277-298, 2013. DOI: http://dx.doi.org/10.11606/issn.2316-901X.v0i57p277-298

BORIE, Monique; ROUGEMONT, Martine \& SCHERE, Jacques. Estética Teatral: Textos de Platão a Brecht. Trad. Helena Barbas, $2^{a}$ edição. Lisboa: Fundação Calouste Gulbenkian, 2004.

BORNHEIM, Gerd. Brecht - A Estética do Teatro. Rio de Janeiro: Graal, 1992.

BRECHT, Bertolt. Estudos sobre Teatro. Rio de Janeiro: Nova Fronteira, 2005.

CANDA, Cilene. Formação em Teatro-Fórum: Recepção, Intervenção e Autonomia do Espectador. In Revista Repertório no 20, p. 130-134, Bahia, 2013.

CARLSON, Marvin. Teorias do Teatro - Estudo Histórico Crítico dos Gregos a Atualidade. São Paulo: UNESP, 1997.

CHAUÍ, M. Convite à Filosofia. São Paulo: Ática, 2000.

COSTA, Antônio Carlos Gomes da; COSTA, Alfredo Carlos Gomes da \& PIMENTEL, Antônio de Pádua Gomes. Educação de Vida - Um Guia para o Adolescente. Belo Horizonte: Modus Faciendi, 1998.

COSTA, Iná Camargo. A Hora do Teatro Épico no Brasil. Paz e Terra: Rio de Janeiro, 1996.

COURTNEY. R. Jogo, teatro e pensamento: as bases intelectuais do teatro na educação. São Paulo: Perspectiva, 2001.

DALL'ORTO, Felipe Campo. Centro de Teatro do Oprimido do Rio de Janeiro: $O$ Teatro do Oprimido na Formação da Cidadania. Dissertação de Mestrado em Artes Cênicas - Universidade do Rio de Janeiro. Rio de Janeiro, 2006.

DESGRANGES, Flávio. A pedagogia do espectador. São Paulo: Hucitec, 2003.

FREIRE, Paulo. Pedagogia da Autonomia: saberes necessários à prática educativa. São Paulo: Paz e Terra, 1996. Pedagogia do Oprimido. Rio de Janeiro: Paz e Terra, 1968. 
GADOTTI, Moacir. Teatro do Oprimido e Educação. In: Metaxis - A Revista do Teatro do Oprimido. Periódico institucional do CTO-Rio. No 3 - Rio de Janeiro, 2007.

GARCIA, Silvana (org.). Odisséia do Teatro Brasileiro. São Paulo: Ed. SENAC, 2002.

GUINSBURG, J. Dicionário do Teatro Brasileiro - temas, formas e conceitos. São Paulo: Perspectiva, 2009.

JAUSS, Hans Robert. A história da literatura como provocação à teoria literária. Trad. Sérgio Tellaroli. São Paulo: Ática, 1994. (Série Temas, v.36).

A Estética da Recepção: Colocações Gerais. In: LIMA, Luiz Costa (Coord. e Trad.). A literatura e o leitor: Textos de estética da recepção. 2. ed. rev. e ampl. Rio de Janeiro: Paz e Terra, 2002a. p. 67-84.

LIBÂNEO, José Carlos. Organização e gestão da escola: teoria e prática. In Cap. II Uma escola para novos tempos. Goiânia: Editora Alternativa, 2004.

LUKÁCS, György. Arte e sociedade: escritos estéticos 1932-1967. Organização, apresentação e tradução Carlos Nelson Coutinho e José Paulo Netto. Rio de Janeiro: Editora UFRJ, 2009. Coleção Pensamento crítico, nº 13.

MAGALDI, Sábato. Panorama do Teatro Brasileiro. São Paulo: Global Editora, 2001. Um Palco Brasileiro - O Arena de São Paulo. São Paulo:

Brasiliense, 1984.

MARTINS, Marcos Bulhões. Encenação em jogo: experimento de aprendizagem e criação do teatro. São Paulo: Hucitec, 2004.

MORENO, J. L. Teatro da Espontaneidade e Psicodrama. São Paulo: Summus, 1984.

NUNES, S. B. 3 ou 4 perguntas para um bom fórum. Metaxis - A revista do teatro do oprimido. Coleção Estudos; Rio de Janeiro: [s.n.], n.1, 2004.

PAREYSON, Luigi. Os problemas da estética. Trad. de Maria Helena Nery Garcez. $3^{\text {a }}$ ed. São Paulo: Martins Fontes, 1997.

PUPO, Maria Lúcia S. B. Entre o Mediterrâneo e o Atlântico, uma aventura teatral. São Paulo: Perspectiva: CAPES - SP: FAPESP - SP, 2005.

. Palavras em jogo. Textos literários e teatro - educação. Tese de livre-docência. São Paulo: ECA/USP, 1997. 
RIBEIRO, Martha. O que faz de uma obra um clássico? In: Poiesis - Revista do Programa de Pós-Graduação em Ciência da Arte - UFF, 2008.

ROSENFELD, Anatol. O Teatro Épico. São Paulo: Perspectiva, 2000. O Mito e o Herói no Moderno Teatro Brasileiro. São Paulo:

Perspectiva, 1982.

SANCTUM, Flavio. Estética do Oprimido de Augusto Boal - Uma Odisséia pelos Sentidos. Dissertação de Mestrado, Programa de Pós Graduação em Ciência da Arte Universidade Federal Fluminense. Rio de Janeiro, 2011.

Boal e a Arte - Um Breve Estudo da Estética do Oprimido. In:

Márcia Denise Pletsch; Gabriela Rizo. (Org.). Cultura e Formação - Contribuições para a Prática Docente. 01 ed. Seropédica: UFRRJ, 2010, v. 01, p. 186-194.

. Curinga - Investigador de Alternativas. In: Tânia Baraúna

Teixeira. (Org.). De freire a Boal: Pedagogia del Oprimido / Teatro del Oprimido. 1 ed. Barcelona: Naque, 2009.

SANTOS, Desirree dos Reis. Novos Horizontes: As criações teatrais de Augusto Boal nos anos de exílio. Dissertação de Mestrado, Programa de Pós Graduação do Departamento de História - Pontifícia Universidade Católica do Rio de Janeiro. Rio de Janeiro, 2014.

SOARES, Luis Cláudio Cajaíba. Espectador: contemplar ou ser contemplado? In:

Portal ABRACE, 2010. http://www.portalabrace.org/vicongresso/teorias/. Acesso em 03/10/2012.

STANISLAVSKI, Constantin. A preparação do ator. 20. Ed. Tradução: Pontes de Paula Lima. Rio de Janeiro: Civilização Brasileira, 2004.

VIANNA, Tiche \& STRAZZACAPPA, Márcia. Teatro na Educação: reinventando mundos. In: FERREIRA, Sueli (org.). O ensino das artes: construindo caminhos. Campinas, SP: Papirus, 2001.

Site: www.cto.org.br 
ANEXOS 


\section{ANEXO I \\ DECLARAÇÃO DE UTILIZAÇÃO DO ESPAÇO}

Declaro para os devidos fins, que a professora Silvia Beatriz Paes Lima Rocha Garcia, portadora da identidade $n^{\circ} 1620626$, CPF $666481901-59$ e Professora de Teatro da Escola Parque 313/314 Sul, tem permissão para utilizar o espaço da referida escola - Teatro de Arena e o Auditório - para ministrar a Oficina de Teatro do Oprimido.

Essa oficina será desenvolvida com alunos do Centro de Ensino Médio do Setor Oeste CEM-SO e do Centro Educacional 03 do Guará - CENTRÃO, realizado sem fins lucrativos e com objetivo educacional para pesquisa de mestrado do PROF-ARTES da Universidade de Brasília.

Brasília, 04 de agosto de 2015.

Atenciosamente,

Regina Darc Rodrigues Guedes

Diretora de Escola Parque 313/314 Sul. 
ANEXO II

TERMO DE ARUTORIZAÇÃO DE USO DE IMAGEM

$\mathrm{Eu}$, portador(a) de cédula de identidade $\mathrm{n}^{\mathrm{O}} \longrightarrow$ responsável legal pelo(a)menor portador(a) de cédula de identidade $\mathrm{n}^{\mathrm{o}}$ autorizo a gravação em vídeo da imagem e depoimentos do(a) menor supracitado(a), bem como a veiculação de sua imagem e depoimentos em qualquer meio de comunicação para fins didáticos, de pesquisa e divulgação de conhecimento científico, elaboração de produtos e divulgação de projetos audiovisuais sem quaisquer ônus e restrições.

Fica ainda autorizada, de livre e espontânea vontade, para os mesmos fins, a cessão de direitos da veiculação das imagens e depoimentos do(a) menor supracitado(a), não recebendo para tanto qualquer tipo de remuneração.

Brasília, 13 de agosto de 2015.

Assinatura do(a) responsável legal 


\section{ANEXO III \\ Peça Teatro-Fórum \\ $\underline{\text { Transições de Impacto }}$}

\section{- CENA 1 - ACONTECEU COMIGO...}

Os atores entram em fila com uma blusa grande branca, cada um com uma vela, se posicionam lado a lado de costas para o público. Deixam a vela no chão, pegam um objeto cada um, o seguram em frente a barriga, viram-se, vão em direção a plateia e falam:

Aconteceu comigo com meu pai.

Aconteceu comigo por dentro.

Aconteceu comigo na escola.

Aconteceu comigo dentro da barriga da minha mãe.

Aconteceu comigo na garagem.

Aconteceu comigo nas estradas.

Aconteceu comigo no meu quarto.

Aconteceu comigo na bebida.

[O último a falar a frase questiona a plateia]:

E com você aconteceu como?

\section{- CENA 2 - MÚSICA.}

Todos começam a indagar a plateia. Um som de violão interrompe e dá-se início à música. Os atores deixam os objetos na frente do palco e ainda cantando arrumam todo o cenário no palco, enquanto alguns atores se posicionam em forma de $V$ e cantam junto:

Não dá mais,

Aja com a Paz! Aja com a Paz!

Já não dá mais,

Aja com a Paz! Aja com a Paz.

Já não dá mais pra viver desesperançado 
Eu sou diferente, porém aproximado

Eu me aproximo, mas não pra comparar

Porque no mundo de hoje, muitos querem roubar

Querem prometer igualdade social

Mas se parar pra ver todo mundo fala igual

Eles fazem promessas e falam demais

Tem gente que fala muito, mas pouco faz

Baseados em fatos reais

São baseados bolados nos jornais

Baseados em fatos reais

São baseados bolados nos jornais

Não dá mais,

Aja com a Paz! Aja com a Paz!

Já não dá mais,

Aja com a Paz! Aja com a Paz

Salve, salve o pátria amada Brasil

Eu mando os opressores lá pra puta que o pariu

Não sabem amar, eles só sabem julgar

Querem te oprimir até você não aguentar

Eu exponho aqui a minha indignação

Por parte de quem curte fazer a opressão

Com opressão no planalto central

Me sinto incapaz de sorrir na capital

Opressão no planalto central

Me sinto incapaz de sorrir na capital

E não dá mais,

Aja com a Paz! Aja com a Paz!

Já não dá mais,

Aja com a Paz! Aja com a Paz! 


\section{- CENA 3 - JOGO DE CARTAS.}

Logo após a música, os personagens se posicionam no centro do palco. Estão jogando cartas enquanto conversam (Atrás de cada um há outra pessoa que representa cenas da infância de cada um enquanto suas histórias são contadas):

Thalis: Sabe, estar aqui com vocês é tão bom, posso esquecer os problemas lá de casa.

Gama: Realmente, é muito bom, lá em casa é muito difícil sabe?

Jiló: Por quê?

Gama: Desde criança eu vejo meu pai chegando bêbado... (Marcelo: Oi pai.), sempre fedendo a bebida. Eu tentava contato com ele, mas ele sempre me batia (Marcelo: Para pai, está me machucando, para). Era muito difícil, sabe?

Jiló: Nossa, sinto muito... Comigo também era muito difícil, quando eu era menor, meu tio sempre vinha "brincar" comigo (Dara: Oi tio!)

Thalis: E isso é ruim?

Jiló: É, quando seu tio abusa de você, eu falava que não (Dara: Para tio, minha mãe disse que isso é meu...), mas ele não parava, teve uma vez que ele me jogou no chão...

Thalis: E você não fazia nada?

Jiló: Fazer o quê? Eu era uma criança.

Thalis: Lá em casa também era muito complicado. Minha mãe nunca me deu muita atenção, eu a elogiava, mas... (Preto: Oi mãe, a senhora está bonita... Mãe, mãe...) Era sempre assim... Teve uma vez que eu ia fugir de casa, mas quando cheguei, minhas malas estavam todas no chão (Preto: O que é isso mãe?) ela mandou eu ir pra minha vó. (Preto: Eu não quero ir pra minha vó, eu quero ficar com você mãe!)

Jiló: E como era com sua vó?

Thalis: Era pior...

Gama: BATI! Galera, já tá tarde, vamos?

Jiló e Thalis: Vamos.

Preto, Marcelo e Dara levantam e cantam a música da infância: 
Preto (Boi da cara preta): "Mãe, mãe, mãe, mãe da cara preta pega esse amor que eu te dei e aceita."

Dara (Ciranda cirandinha): "Ciranda, cirandinha, o meu tio me estuprava, eu dava a meia volta e ele queria mais."

Marcelo (Peixe vivo): "Como pode o meu pai chegar bêbado todo dia, como pode o meu pai me bater todo dia, como poderei viver, (todos) como poderei viver..." Aos poucos, ainda cantando, os atores saem de cena.

\section{- CENA 4 - LUZ DE VELAS.}

Todos entram em cena segurando uma vela sussurrando "Atitude Incompreensivel", andando em direções diferentes. A sobrinha, sem vela, pára no meio e diz:

Sobrinha: Mãe! Mãe! Por que você não me ouve? Por que você não acredita em mim? Você acha que só porque ele é seu irmão e vive aqui dentro de casa, ele não me toca? Me escuta!

Pega a vela do Tio e continua caminhando. Ele para no centro e fala:

Tio: Era só uma garotinha, mas era tão gostoso tocar em cada parte do seu corpo. Eu não vejo nada de errado nisso.

Ricardo: Todas as vezes que você disse que não me amava e me maltratava eu fui abortado.

Puta: Alguns clientes ainda perguntam por que eu não saio dessa vida, mas a resposta sempre foi e sempre será a mesma: eu não saio dessa vida, porque hoje eu tenho tudo que eu nunca tive, hoje eu sou LIVRE!

Jiló: Eu tinha apenas 16 anos, não sabia o que fazer, estava com medo aí ... eu matei. Todos assopram e apagam as velas:

Todos: ATITUDE IMCOMPREENSÍVEL.

Saem. 


\section{- CENA 5: - AVÓ COM CARTAZ - ESTATÍSTICA.}

Dara entra vestida de vó, com um cartaz na mão escrito "70\%".

Atriz: $70 \%$ das crianças vítimas de agressão, sofrem essa agressão em casa. (Abaixa o cartaz como se fosse um pano de chão e interpreta a avó).

Vó: Melhor em casa do que na rua, né? Tem que apanhar em casa pra ser corrigido, pra aprender a ser gente direita. Esse foi o meu erro com aquela vagabunda da minha filha. Devia ter quebrado os dentes dela quando tive a chance. Pelo menos hoje seria alguém na vida, não tinha que cuidar daquele moleque, filho dela. Imprestável, não serve pra nada. Aquilo é uma desgraça, um estorvo na minha vida...

Sai de cena.

Jane entra com outro cartaz na mão escrito: "Gravidez na Adolescência”.

Atriz: 75\% das adolescentes que tem filhos desistiram de ir à escola. (Abaixa o cartaz e segue pra próxima cena).

\section{- CENA 6 - OPRIMIDO REJEITADO.}

Entra em cena Carlos Alberto. Coloca uma cadeira e se senta. Ele está sentado lendo jornal quando Jaqueline se aproxima e diz:

Jaqueline (Com o filho nos braços): Carlos Alberto o que vamos fazer com isso?

Carlos Alberto: Faça o que quiser, o filho é seu.

Jaqueline: Eu não fiz com o dedo não, ok?

Carlos Alberto: E a culpa é minha? Você não ter usado a porcaria do Anticoncepcional direito?

Jaqueline: É sim!!

Carlos Alberto: Olha pra essa coisa, puxou tanto a sua feiura que acabou não puxando nada de mim.

Jaqueline Como não puxou nada de você Carlos Alberto?

Carlos Alberto: Não puxou nada Jaqueline, eu não tenho esse rosto feio e esse cabelo ridículo que herdou de você. 
Jaqueline: Ele não tem só o cabelo cacheado não, também pegou uma parte sua seu inútil. Agora chega de conversa fiada, vai me ajudar com ele ou não?

Carlos Alberto: Já falei que não. Eu não vou cuidar dessa aberração, eu não mandei você tê-lo, agora você tem uma escolha: ou ele ou eu?!

Jaqueline joga o bebê na cadeira e vai atrás de Carlos Alberto e os dois começam a discutir ao mesmo tempo. Enquanto isso, a Vó, mãe de Jaqueline, entra e observa o bebê jogado na cadeira e interrompe a discussão:

Vó: Ô minha filha, tu vai deixar esse troço jogado desse jeito aqui?

Jaqueline: E se eu deixar? Qual é o problema? O que você tem a ver com isso?

Vó: O que eu tenho a ver? Vai sobrar pra mim cuidar desse troço e eu não tenho obrigação nenhuma de cuidar dos erros dos outros. Toma vergonha nessa tua cara de vagabunda e se responsabilize pelos seus atos, por mais imbecis que eles sejam.

Jaqueline: Você não tem absolutamente nada a ver com a minha vida. O filho é meu e eu faço o que eu quiser com ele. Se eu quiser jogar no lixo, eu jogo.

Vó: Joga porra nenhuma! Tu é de menor sua imbecil, se tu fizer essa merda, eu que vou responder por isso. Tu só joga esse troço no lixo por cima do meu cadáver. Foi gostoso fazer, não foi? Foi bom dar pra esse idiota aí, né?

Jaqueline: Foi mesmo!

Vó: Pois agora tu vai cuidar dessa peste aqui querendo ou não. Seja mulher suficiente pra assumir a merda que fez. Eu ainda avisei. Isso que dá abrir as pernas pra qualquer um com 17 anos. Perdeu tua adolescência por causa desse babaca...

Carlos Alberto: (Irritado interrompe): Olha pra mim chega! Eu vou embora daqui.

Jaqueline: Mãe, aconteceu.

As duas saem de cena.

\section{- CENA 7 - RESPIRO I - TOTALMENTE INCOMPREENSÍVEL!}

Entra Nathália, coloca uma cadeira e senta no centro do palco:

Nathália: Todas as vezes que eu vejo um mendigo na rua, me pergunto por quê ele tá ali? O que tá fazendo ali? 
-Vai trabalhar vagabundo?!

-Vai procurar o que fazer?!

Não entendo por quê não limpam eles da rua. Só fede, só enfeia o lugar.

Atitude Incompreensível!

\section{- CENA 8 - PUTA.}

O palco está escuro com somente uma cadeira e uma luz no centro. A prostituta entra do fundo da plateia, brincando com os espectadores até o palco. Para ao lado da cadeira, e encara a plateia:

PUTA- Que foi, querido? Nunca viu uma mulher como eu não? "Censinho" a hora, tá afim? Não sei o que é melhor, a cara dele ou a de vocês. Pô, eu podia tá matando, eu podia tá roubando, mas eu só tô dando, cara.

Vira a cadeira e senta de pernas abertas para o público, encarando-o ironicamente, e começa a questioná-lo, sempre chamando atenção de alguém e esperando resposta:

Ei, você aí... Tu teve infância? Como foi? E você ai? Cê teve? Foi boa? Aé? Porque eu não sei o que é isso. Eu cresci com meu pai. Com o filho da puta do meu pai. Com o desgraçado filho da puta do meu pai.

Alguém já te bateu? Alguém já chutou a sua alma? Alguém já socou o seu ego? "Mas nossa, como você tem experiência de vida" (Imitando a voz de alguém com desdenho) "Experiência". Um dia vão te meter uma bala na cara e você vai achar que é uma experiência...

Eu tinha sei lá, uns 14 anos. (Um por um alguns homens começam a entrar e tocam delicadamente a prostituta) Cheguei da escola e meu pai tava sentado no sofá com um litro de 88 na mão. Pela metade. Depois disso só lembro dos chutes. Ele gritava e xingava muito. Dizia um monte de coisas, mas uma eu nunca vou esquecer. Ele me chamou de assassina. "Sua mãe não tá aqui por que você nasceu, sua vadiazinha de merda". “Assassina!”

É talvez eu tenha merecido a surra. Talvez eu tenha merecido quebrar o maxilar e 3 costelas. Talvez! Eu não conseguia falar pra ninguém o que tava acontecendo... até eu fazer 17 anos e descobrir que estava grávida dele (Os homens se afastam com nojo e 
saem de cena). Mas aí eu não precisei falar pra ninguém. Não foi a polícia que me livrou dele. Nem Deus né, até porque, a essa altura, ele nem existia mais. Bastou uma garrafa de cachaça e alguns remedinhos. Pronto!

E a minha filha? Pensem comigo: eu morro, tu morres, ele morre; nós morremos, vós morreis, eles morrem, vocês também morrem, todo mundo morre, teu pai morre, tua mãe morreu, teu filho morrerá e minha filha morreria se tivesse nascido!

Olha só, ainda dizem que puta não é inteligente. Depois disso, quando vejo uma mulher grávida penso: esse defunto ainda não nasceu. E aí olho pra ela e penso: Um cadáver adiado que procria. Mas aí vai de cada um, procria quem quiser. Mas agora eu tô feliz. Tô ótima. Alguns clientes ainda perguntam por que eu não saio dessa vida, mas a resposta sempre foi e sempre será a mesma: eu não saio dessa vida, porque hoje eu tenho tudo que eu nunca tive, hoje eu sou LIVRE!

\section{- CENA 9 - ESTUPRO.}

A menina (Dara) chega em casa com uma sacola na mão procurando pela mãe:

Sobrinha: Mãe? Mãe? Cheguei.

Do outro lado, entra o tio-Álvaro:

Tio: Oi princesa, chegou é?

Sobrinha (se desespera): Cadê minha mãe?

Tio: Ela deu uma saidinha. Mas como você tá? Como foi seu dia? (Ela fica calada)

O meu tá bem melhor agora sabia? Isso ai é um presentinho pra mamãe?

Sobrinha: Não te interessa. (Tenta chamar a mãe mais uma vez) Mãe?

Tio: Calma amorzinho. Deixa eu ver, me dá aqui (toma a sacola da menina). Eu também tenho um presentinho pra você, olha aqui. (mostra a camisinha)

Sobrinha: Nojento!

Tio (A puxa pro centro do palco acariciando com firmeza): Hum, como você tá linda hein? Cheirosa... Tudo isso é pra mim? Também tava com saudade.

Sobrinha: Sai! Sai! (começa a lutar, tentando se soltar do tio) 
Tio: Vem cá, vem! (pega forte, a leva para a parede e depois para o chão. Ela luta até não aguentar mais, então desiste e ele a lambe).

BLACKOUT.

\section{- CENA 10 - RESPIRO II - TOTALMENTE INCOMPREENSÍVEL!}

Entra Nathália, coloca uma cadeira e senta no centro do palco:

Nathália: Semana passada fui arrumar meu cabelo num salão super chique. Quando entra uma menina do cabelo ruim. Opa... Do cabelo cacheadinho...

E fala pra cabeleireira que quer fazer um corte que realce seus cachos.

-O quê? Realçar? Vai alisar isso menina! Não tá vendo que tá feia?!

Atitude Incompreensível!

- CENA 11 - CORINGA.

Entra O Coringa (Gnomo):

Coringa: O que é Opressão? Opressão é o ato de oprimir, sufocar, seja uma pessoa, uma atitude, uma comunidade.

E o que é Oprimir?

Verbo Transitivo Direto.

É fazer a pessoa submeter-se a tal coisa, pela autoridade, brutalidade, força.

Prefixo "OPR" !

Eram? Conjugação do verbo ser. Aquilo que “era" mas agora não é mais...

OPRIERAM!

- CENA 12 - RELAÇÃO AMOROSA.

Entra um casal, e se sentam um ao lado do outro, de frente para a plateia:

Mulher: Quando a gente namorava ele era tão carinhoso comigo...

Homem: Quando eu pedi ela em namoro ela me dava mais atenção. 
M: Depois que o nosso primeiro filho nasceu, as coisas começaram a mudar.

H: A nossa vida a dois tinha acabado, ela não me escutava.

M: Eu aposto que ele tá me traindo com aquela tal de Gabi. Eu sempre vejo os dois de conversar na rua.

H: Eu não conseguia conversar com ela cara a cara, então... eu falava com a Gabi.

M: Ele é tão machista, uma vez ele me deu um tapa na cara porque eu não lavei a louça.

H: Sabe quando você chega tão cansado em casa e vê tudo sujo? Depois dizem que mulher não provoca o homem... ela me provocou tanto... me deixou tão nervoso, que minha raiva só passou quando dei uns tapas nela.

M: Eu o amava tanto. Acho que ainda amo, mas agora tá tudo tão diferente. Eu queria que fosse como antes.

H: Eu gostava tanto dela... Acho que ainda gosto, mas não sei como dizer.

Os dois saem de cena.

-CENA 13 - CARTAZ - ABANDONO.

Entram Preto, Ivan, Thalis e Gnomo com cartazes:

Ivan (segurando um cartaz com desenho de dois homens se abraçando): Eu abandonei o meu pai quando ele quis me dar um abraço e eu recusei.

Thalis (segurando um cartaz com desenho de duas mãos): Eu abandonei minha vó quando ela me chamou de mal educado e eu dei um tapa na cara dela.

Preto (segurando um cartaz com desenho de uma garrafa de bebida): Eu abandonei minha mãe quando ela queria falar comigo e eu saí pra beber com meus amigos.

Gnomo (segurando um cartaz com desenho de um joystick): Eu abandonei meu irmão quando deixei de dar um abraço nele pra ficar jogando vídeo game.

-CENA 14 - SURRA NA ALMA.

Entra a mãe (Nathália) procurando algo:

Mãe: Ô menino, vem aqui 
Filho: O que é mãe?

Mãe: Cadê minha chinela?

Filho: Eu que vou saber?

Mãe: Trás ela aqui agora...

Filho entrega a chinela com desdém.

Mãe: E que bagunça é essa aqui nessa casa?

Filho: Eu que vou saber?

Mãe: Pois comece a arrumar agora.

Filho: Eu arrumar? É sua obrigação como mãe arrumar a casa.

Cena congela, entra o narrador, Gnomo/Coringa:

Coringa: Aquele dia eu levei uma surra... mas foi uma surra na alma.

Volta cena e mãe bate no filho.

Mãe: Você me respeita que eu sou sua mãe.

Filho: Você é louca.

Mãe joga sandália no filho, joga ele no chão.

Mãe:.Nunca mais fale comigo dessa maneira, sou eu que te sustento vagabundo!

Filho sai de cena resmungando.

•CENA 15 - OPRIMIDO EXPULSO.

Ricardo (Paulin), o filho, está sentado assistindo TV quando Jaqueline entra com uma mochila:

Jaqueline: Tira o pé do meu sofá! Toma, vai pra casa da sua avó!

Ricardo: Hã?

Jaqueline: Vai para casa da sua avó, não entendeu?

Ricardo: Como assim casa da minha avó? Você ta bem mãe?

Jaqueline: Estaria ótima de você não estivesse aqui. Tchau! 
Ricardo: Você está me expulsando de casa de novo? Como assim ?

Jaqueline: É, tô sim. Cansei de você, da sua cara, não aguento mais.

Ricardo: Mas mãe...? Eu não faço, nada fico no meu canto e nunca...

Jaqueline: Esse é o problema, você não faz nada.

Ricardo (indignado): Como assim? Eu estudo e além disso limpo a casa toda.

Jaqueline - GAROTO! TCHAU! Vai logo, tenho que ir pro salão.

Entra o namorado (Álvaro) de Jaqueline e dá um beijo nela:

Namorado: Oi amor.

Jaqueline: Oi meu lindo.

Namorado: O que esse muleque ainda ta fazendo aqui?

Jaqueline: Esse resto de aborto vai embora hoje!

Namorado: Garoto, sai da minha casa, anda vaza.

Ricardo: Primeiro, não é sua casa, e segundo, isso aqui eu resolvo com ela. (para mãe) Por favor, deixa eu ficar. Não quero ir pra casa daquela mulher mais uma vez

Jaqueline: Não vai ficar! Você me irrita, vai pra lá sim, e se voltar mando de novo, ai vai ser a terceira pra completar o pacote.

Ricardo: Mãe!! (Ajoelha-se) Deixa eu ficar aqui.

Namorado chuta o menino.

Jaqueline - Não me chama de mãe! Não quero ser sua mãe. Você não é filho pra mim. Você é apenas um resto de aborto.

Neto pega a mochila olha pra mãe com olhar triste e sai. Jaqueline sai com o namorado e do outro lado entra a Vó. Senta na cadeira lendo alguma coisa enquanto a empregada limpa a casa. Alguém bate na porta:

Vó: Maria, não está escutando a porta bater?

Maria: Me chamou senhora?

Vó: Vai atender a porta imprestável. Pago caro para ter um serviço ruim desses.

Maria abre a porta 
Maria: Meu filho!!!

Ricardo: Maria! (abraça Maria). Como eu senti sua falta.

Maria: Também senti sua falta. Mas..mas.. o que você tá fazendo aqui meu filho?

Ricardo: Minha mãe me mandou pra cá.

Maria: Mas meu filho, você não pode voltar para essa casa. Logo agora que você se livrou dela.

Ricardo: Eu sei Maria, mas a louca da minha mãe me expulsou de novo. Não tenho para onde ir.

Maria: Mas essa aqui é mais louca ainda. Você tem que ir para outro lugar.

Ricardo: Que outro lugar Maria? Sou sempre abandonado.

O menino chega diante da avó.

Ricardo: Oi vó.

Vó: O que tu pensa que tá fazendo aqui, moleque?

Ricardo: Minha mãe me expulsou de casa.

Vó: E daí? Desde quando isso é problema meu?

Ricardo: Eu preciso de um lugar pra ficar vó...

Vó: Problema seu! Tu não vai ficar aqui de novo.

Ricardo: Por favor Vó, eu não tenho onde ficar...

Vó: A rua tá ai pra isso.

Ricardo: Por favor, só por um tempo. Eu não to pedindo pra você me amar e nem gostar de mim, eu faço o que você quiser, por favor.

Vó: SAI DAQUI!!

Ricardo (Ajoelha): Pelo amor de Deus Dona Carmen. Eu te imploro.

Vó: 3 meses. Só. Você vai ter que trabalhar, lavar a sua roupa, a sua louça e a de todo mundo aqui.

Ricardo: Mas de todo mundo Vó? 
Vó: Prefere ficar na rua?! Pode ficar no quarto de hóspedes. Mas você vai dormir no chão.

Maria: Mas dona Carmem, no chão? Nem eu durmo no chão.

Vó: Cala a boca Maria. Sim, no chão. Se chegar um hóspede ele tem onde dormir.

Ricardo: Tudo bem Vó. Obrigada.

Vó: Ei moleque. Olha aqui, escuta bem o que eu vou te falar, tu vai ficar aqui sob as minhas ordens. Tu vai fazer tudo que eu mandar e se desobedecer eu te jogo na rua. Entendeu?

Ricardo: Está bom. (olha para Maria com olhar de tristeza).

Maria: Oh meu filho...

Neto: Pelo menos aqui eu tenho você.

Os dois saem de cena

Vó: Só era o que me faltava. Ter que aturar essa peste aqui dentro de casa... (Sai de cena).

\section{- CENA 16 - GIRA A ROLETA.}

Entra o pai (Gnomo), vira de costas para o público e coloca um nariz de palhaço. Virase e então entram vários filhos dentre eles os que vão questionar o pai, todos correndo em volta dele em roda e parando para cada pergunta:

Pai: Vamos brincar de roda-roda, vai rodando. Número 8!

Marcelo: Pai por que minha pele é escura?

Pai: Meu filho, é porque sua mãe tomava muito café na sua gravidez. Comia muito chocolate. Por isso.. Agora vamos rodar mais uma vez. Número 11!

Preto: Pai, meus amigos ficam zombando de mim só porque eu gosto de brincar de boneca.

Pai: Mas você só brinca de boneca?! Não meu filho. Se você é aberto para brincar de boneca, por que você não se abre para brincar de outras coisas?? Jogar bola, brincar de carrinho.. Você deveria experimentar, acho que seus amiguinhos iriam parar de implicar com você. Vamos lá, roda a roda. Número 15!! 
Jiló: Pai, por que meu cabelo é assim??

Pai: Ora minha filha porque Deus quis... pois é, na hora que Ele escolheu você Ele decidiu que iria botar na sua cabeça mais ondas que no oceano atlântico e.. botar nos seus olhos a cor da noite e veio você, essa coisa linda.. Mas continua rodando aí vai.. Numero $24 ! !$

Paulin: Pai, por que eu gosto de ficar me tocando?

Pai: Como é menino?? Como assim??

Paulin: É. Eu gosto de sentir meu corpo, mas eu fico com a mão fedida, sinto dores..

Pai: Ufa meu filho..(despreocupado) olha, isso é só uma faze, daqui a um tempo você vai procurar novas sensações e vai ver que essa sensação é ainda melhor quando você não precisa usar as mãos no seu corpo. Vamos rodando!!Então todos começam a questionar o pai e rodar mais rápido.

Todos: Por que pai?! Mas por quê?

O pai assobia botando o nariz de palhaço.

Pai: Chega! Eu tenho cara de palhaço por acaso?! Não respondo mais nada. Se quiser saber mais alguma coisa pergunte para sua mãe.

\section{•CENA 17 - MÃE E FILHA - QUADRIPLICADA.}

Quatro filhos entram em cena a procura de seus pais:

Filha: (Nathália): Mãe, mãe.

Filho 1: Mãe (ou Pai)

Filho 2: (Dara): Pai

Filho 3: Mãe (ou Pai)

Mãe (Camila): Não me chama de mãe.

Mãe 1: Não me chama de mãe(ou pai).

Pai 2 (Thalis): Não me chama de pai.

Mãe 3: Não me chama de mãe (ou pai). 
Mãe: Cala a boca sua vagabunda, eu não sou a sua mãe, eu não sou a sua mãe! Para de repetir isso, para, chega! Eu nunca te quis, nunca.

Mãe 1: eu nunca te quis.

Pai 2: eu nunca te quis.

Mãe 3: eu nunca te quis.

Filha: para com isso, mãe.

Mãe: Tudo culpa daquele (filha da puta) do seu pai. Ele disse que ia me ajudar. Eu devia ter te tirado...

Filha: mãe, não fala isso.

Mães (ou pais) dão um tapa nos seus filhos. Filhos caem no chão e Pais congelam. Levantam um de cada, de acordo com suas falas.

Filha: Engraçado como eu não pedi nada. Eu não pedi um celular, um quarto só meu ou uma festa de aniversário. O que queria era poco, era diferente de tudo isso. Eu só queria um beijo de boa noite. Um abraço...

Filho 1: Eu só queria não ser culpada.

Filha: Eu só queria que você me dissesse um "minha filha, eu te amo"

Filho 2: Eu só queria poder te dizer eu te amo.

Filha: Eu só queria poder te chamar de mãe.

Filho 3: eu só queria poder te chamar de pai.

Filha: Eu quero sentir. Só quero sentir. E não se sentir amada é horrível, por isso que eu te amo, mãe, por isso que eu te amo.

Os filhos abraçam os pais congelados e deitam no chão na posição em que caíram.

Mãe: vai embora da minha casa, eu não aguento mais você. Vai! Quer saber? Quem vai embora sou eu. Sua vadiazinha.

Mãe 1: Sua vagabunda(ou vagabundo)

Pai 2: Seu vadia

Mãe 3: Seu ? 


\section{- CENA 18 - RESPIRO III - TOTALMENTE INCOMPREENSÍVEL!}

Entra Nathália, coloca uma cadeira e senta no centro do palco:

Nathália: Em muitas casas existem filhos que não se sentem amados por suas mães. Existem filhos que tem muito, mas ao mesmo tempo não possuem nada. Existem mães que não entendem seus filhos e filhos que não entendem suas mães. É o que dizem um para o outro. Só que esqueceram de dizer e compreender o significado de amar. O significado de ser. Atitude totalmente incompreensível.

\section{•CENA 19 - ESTUPRADINHO.}

Entra um garoto (Preto) assustado e senta-se no centro do palco, enquanto uma voz (Thalis) lhe interroga:

Voz: Qual seu nome?

Menino: Pedro

Voz: Quantos anos você tem?

Menino: 17

Voz: Você lembra de como era o rosto dele?

Menino: Não

Voz: Você lembra qual a cor dele? Do cabelo dele?

Menino: Já disse que não, só lembro que doeu.

Voz: O que ele fez com você?

Menino: Ele me machucava, era horrível, eu tinha que ficar escondendo as marcas roxas no meu braço todos os dias.

Voz: O que ele fazia com você?

Menino: Eu já disse, ele me machucava, passava a mão em mim, era nojento mas eu não podia fazer nada, eu pedia pra ele parar mas... Eu tinha medo.

Voz: Por que você não contou pra ninguém?

Menino: Por medo, tinha medo do que ele poderia fazer comigo, ou contra a minha família, conta minha mãe... 
Voz: Tenho uma ultima pergunta: Como você se sente agora?

Menino: Me sinto mutilado.

\section{-CENA 20 - ESCOLA.}

Dois garotos (Marcelo e Thalis) conversam numa sala de aula enquanto uma garota (Jiló) está quieta em seu canto. O professor (Gama), vendado, entra e cumprimenta os alunos:

Professor: Bom dia

Ninguém responde.

Professor: BOM DIA!!

Valentões: Bom dia pra quem?! Cala sua boca!

Entra o um garoto tímido (Ivan).

Tímido: Desculpa pela demora, professor.

Entrega a flor para Camila.

Valentão 1 (Thalis): Olha o viadinho aí

Valentão 2 (Marcelo): Uma flor dando outra flor.

Camila levanta e vai até a lixeira, na volta, Marcelo passa a mão nela.

Valentão 2: Deixa eu apagar seu fogo, sua gostosa?!

Todos congelam, Camila vai ao centro do palco.

Camila: É isso todo dia! Eu me sinto constrangida, será que eles não percebem? Me sinto desrespeitada, violada... Eu não conto pra ninguém, fico muito sem graça, até pq isso é tão normal neh?! Sem contar que sou mulher, sinto medo, impotência perto de tantos homens! Mas será que eles não percebem? Será? Será que da pra eu ser assim mesmo? Pq olha, ninguém vê, ninguém fala...Atitude totalmente incompreensível.

Todos descongelam.

Valentão 1: Vagabunda, não da moral pra esse viado aí não.

Valentão 1 se levanta e vai até Camila, ele passa a mão nela e depois todos congelam. 
Tímido: Vocês acham que eu não tento fazer nada? Ver a garota que eu gosto todos os dias sendo assediada por esses garotos. Isso não acontece só aqui na escola, na minha família acontece tbm, sempre injustiçado, mas isso tem que parar, essa atitude é ou não compreensível?

Todos descongelam. Tímido volta e ataca os valentões. Ocorre uma briga e o garoto tímido consegue vencer os dois garotos:

Tímido: Vocês nunca mais encostam nela.

Ele bate nos dois e o professor tira a venda.

\section{- CENA 21 - MORTE PASSEIA.}

Entram algumas pessoas com velas e sentam-se. Entra então a Morte (Gnomo) ao som de um atabaque, bate sua bengala ao centro e começa a falar com o público:

Morte: Olá! Prazer sou seu sofrimento, sua dor, a peste negra, seu luto? Meus pêsames. Sou encarregado de um trabalho muito importante. Muita gente não gosta de mim, mas eu gosto muito de todos ainda mais pelo meu trabalho. Se você não sabe quem sou eu ou nunca me viu, então ainda não chegou sua hora. Mas vai chegar viu? Eu vou mostrar pra vocês por que meu trabalho é fundamental e o quanto é divertido.

Se dirige ao ? e enquanto fala passeia ao redor dele. O mesmo com os outros:

Bom, imagine uma criança que tem ódio do próprio pai. Essa criança não deve ter tido uma infância legal. Ele ideia tanto que mata o próprio pai (Assopra a vela).

Se dirige à Camila.

E essa puta?! Teve coragem de matar o filho antes de nascer. Mas como é puta, não faz falta pra ninguém, além do mais nem ela sabe quem passou AIDS pra ela. (Assopra a vela).

Se dirige em direção ao Ivan.

Filho que mata o pai, mãe que mato o filho. Mas ainda sim ha o pai que mata seu filho. (Assopra a vela).

Se dirige em direção ao Thalis. 
Tem vezes que eu nem preciso me esforçar muito, é só levar a pessoa certa, pra famosa "hora errada" no "lugar errado" e pronto. Acidente.(Assopra a vela).

Se dirige em direção Jennifer e Álvaro.

Tem gente que é muito mais fácil. So precisa de um empurrãozinho. Tem gente burra o suficiente pra morrer de amor, sabe, tipo romeu e Julieta. Morreu e necrópsica. (O casal assopra a vela um do outro).

Se dirige em direção ao Paulin.

Ah, os jovens. Acham que são invencíveis, super-heróis. Mas todo herói tem seu ponto fraco.(falando para o jovem) Ta bom?? Ta gostoso?? Então cheira tudo e mais um pouco, ate acabar!! (Assopra a vela).

Se dirige em direção à Nathália.

Mas de todos os tipos de morte que exemplifiquei para vocês a minha preferida é essa aqui. A morte interna. Sabe?! Um "eu te odeio" do seu pai, um sentimento que pode parecer minúsculo no começo, mas essa pessoa tem que conviver com sua morte por toda a sua vida (Assopra o ouvido da jovem e ela canta:)

Nathália: (Se essa rua, se essa rua...): Essa casa, essa casa tem um nome, e se chama, e se chama, opressão. Dentro dela, dentro dela mora um monstro, que roubou que roubou meu coração.

BLACKOUT.

\section{- CENA 22 - O CONFRONTO - CENA-FÓRUM.}

A Vó arruma uma mesa com café da manhã quando chega o neto Ricardo preocupado:

Neto: Vó, desculpa, me perdoa, por favor, eu fiquei até tarde estudando e acabei dormindo demais...

Vó: Eu não to nem ai pro que aconteceu, o teu dever era estar aqui às 07hrs pra preparar o café.

Neto: E a Maria?

Vó: Tá de folga. Agora tem essa né, de dar folga pra criado.

Neto: Desculpa mesmo, Vó. 
Vó: Tá moleque, sai daqui.

Neto: Não vai mais acontecer, eu juro. Deixa que eu preparo o café...

Vó: Deixa. Já to aqui mesmo. (Muda totalmente de atitude) Quer um pãozinho, querido?

Neto: (Assustado): Sério? Claro! Quero sim, to morrendo de fome!

Vó: Quer com muita ou pouca manteiga?

Neto: Muita!

Vó: Dos dois lados?

Neto: Sim, por favor!!!

Vó: Toma, querido. (Joga o pão no chão) Come!

Neto: É sério isso Vó? Eu vou ter que comer do chão?

Vó: Vai! E se deixar alguma migalha no chão vai ter que lamber pra limpar. Anda logo moleque, eu to mandando.

Neto: (Quase pegando o pão se revolta) Quer saber Vó? Não é por que eu to na sua casa de favor que eu tenho que fazer tudo que você quiser. Você pode não gostar de mim mas isso não te da o direito de me tratar como cachorro.

Vó: Eu te trato do jeito que eu quiser, garoto. E você vai comer esse pão.

Neto: Por que Vó? O que eu te fiz? Você nunca me deu um abraço sabia? Nunca ouvi uma palavra de carinho, nem de você e nem da minha mãe. Por que é tão difícil me amar? Eu não tenho culpa. Vocês não podem me tratar assim pelo resto da vida, não.

Vó: E tu acha que eu caio nesse papinho ai? Larga de drama moleque, engole esse choro. A obrigação de cuidar de tu é da tua mãe, vai pedir abracinho e beijinho pra ela. Ali é outra que não tem mais jeito, uma vadia que não serve pra nada.

Neto: Ela deve ter aprendido a ser podre assim com você, né? Mãe não, aquela mulher é tudo menos mãe. Ser chamado de resto de aborto a vida toda.

Vó: Mas você é um resto de aborto. Se eu soubesse que todo esse problema ia vir para mim, eu teria deixado ela abortar de uma vez!

Neto: (de cabeça baixa, olha pra cima) A senhora acha mesmo que eu não fui abortado? Acha mesmo? No dia que ela olhou nos meus olhos e falou que não sou mais 
filho dela, eu fui abortado. Todos os dias na sua casa, sendo tratado como sou tratado, eu sou abortado! Fui abortado a minha vida inteira! ( pausa) Pera, você disse resto de aborto? Então eu....

Vó: E tu só veio descobrir isso hoje?

Neto: Você sabia?

Vó: Foi eu que levei ela na clínica. E tu é tão ruim, que tu sobreviveu a um aborto. Tu sobreviveu a todas as vezes que ela tentou te matar. Tu voltou pra ela todas as vezes que ela te "perdeu" no meio da rua. No começo eu queria que tu sumisse, mas depois percebi que tu seria o pior castigo que a tua mãe poderia receber. Sabe o que tu representa pra ela? A morte da adolescência dela. O pior pesadelo. O peso que ela é obrigada a carregar. Você lembra tudo de ruim que deu errado na vida dela, porque você é o único erro que ela tem que olhar na cara todo dia, e aturar. E sabe o que você representa pra mim? Nada, além de uma pedra no sapato. Agora, come a porra desse pão, ou rua!

Neto abaixa e se prepara para comer o pão. A cena congela. O fórum é aberto. No fim, todos pegam seus objetos e voltam para trás do palco para última cena.

\section{- CENA 23 - A RETOMADA.}

Assim como no começo, os atores se posicionam lado a lado de costas para o público. Dessa vez já com um objeto cada um, o seguram em frente a barriga novamente, viramse, vão em direção a plateia e falam:

Aconteceu comigo, com meu pai

Aconteceu comigo por dentro

Aconteceu comigo na escola

Aconteceu comigo dentro da barriga da minha mãe

Aconteceu comigo, na garagem

Aconteceu comigo nas estradas

Aconteceu comigo no meu quarto

Aconteceu comigo na bebida 
Porém, ao fim de cada fala, solta-se o objeto e revela-se uma mancha de sangue na camisa branca. Ao fim da última frase, a plateia é indagada por todos mais uma vez com a frase "E com você? Aconteceu como?”, com a música novamente.

Não dá mais,

Aja com a Paz! Aja com a Paz!

Já não dá mais,

Aja com a Paz! Aja com a Paz

Já não dá mais pra viver desesperançado

Eu sou diferente, porém aproximado

Eu me aproximo, mas não pra comparar

Porque no mundo de hoje, muitos querem roubar

Querem prometer igualdade social

Mas se parar pra ver todo mundo fala igual

Eles fazem promessas e falam demais

Tem gente que fala muito, mas pouco faz

Baseados em fatos reais

São baseados bolados nos jornais

Baseados em fatos reais

São baseados bolados nos jornais

Não dá mais,

Aja com a Paz! Aja com a Paz!

Já não dá mais,

Aja com a Paz! Aja com a Paz

Salve, salve o pátria amada Brasil

Eu mando os opressores lá pra puta que o pariu

Não sabem amar, eles só sabem julgar

Querem te oprimir até você não aguentar

Eu exponho aqui a minha indignação

Por parte de quem curte fazer a opressão 
Com opressão no planalto central

Me sinto incapaz de sorrir na capital

Opressão no planalto central

Me sinto incapaz de sorrir na capital

E não dá mais,

Aja com a Paz! Aja com a Paz!

Já não dá mais,

Aja com a Paz! Aja com a Paz! 


\section{APÊNDICE}

Foto tirada com o grupo Oprieram, ao término de um dos ensaios.

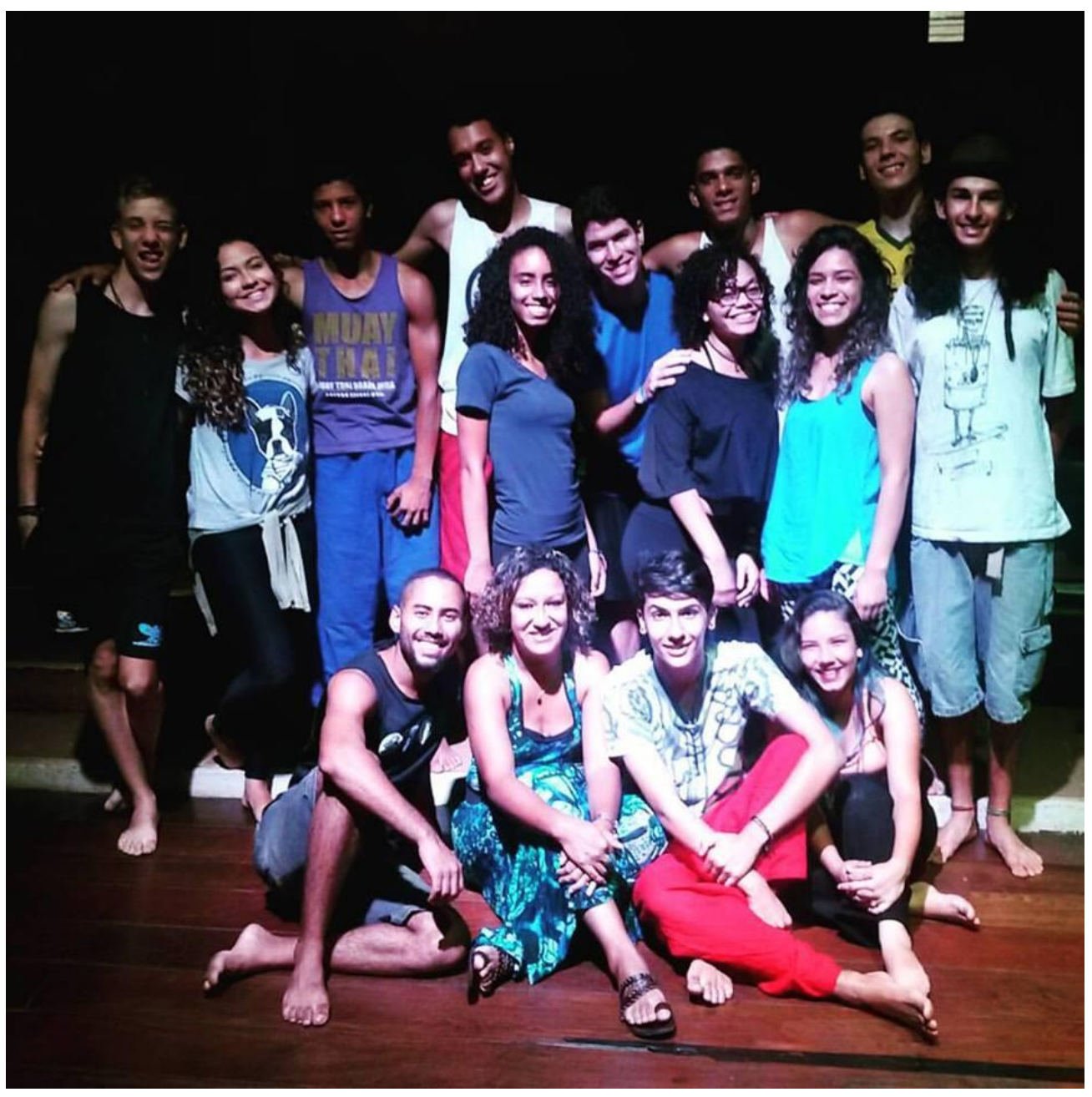

Fotografia de Bruno Garcia - Arquivo da Autora 